\title{
Preliminary Materials Assessment for the Satellite Power System (SPS)
}

U.S. Department of Energy

Office of Energy Research

Satellite Power System Project Office

\section{DOE/NASA}

SATELLITE POWER SYSTEM

Concept Development

and

Evaluation Program 


\section{DISCLAIMER}

This report was prepared as an account of work sponsored by an agency of the United States Government. Neither the United States Government nor any agency Thereof, nor any of their employees, makes any warranty, express or implied, or assumes any legal liability or responsibility for the accuracy, completeness, or usefulness of any information, apparatus, product, or process disclosed, or represents that its use would not infringe privately owned rights. Reference herein to any specific commercial product, process, or service by trade name, trademark, manufacturer, or otherwise does not necessarily constitute or imply its endorsement, recommendation, or favoring by the United States Government or any agency thereof. The views and opinions of authors expressed herein do not necessarily state or reflect those of the United States Government or any agency thereof. 


\section{DISCLAIMER}

Portions of this document may be illegible in electronic image products. Images are produced from the best available original document. 


\section{Preliminary Materials Assessment for the Satellite Power System (SPS)}

January 1980

Prepared by:

R.R. Teeter and W.M. Jamieson

Battelle Columbus Laboratories

505 King Avenue

Columbus, Ohio 43201

Prepared for:

U.S. Department of Energy

Office of Energy Research

Satellite Power System Project Office

Washington, D.C. 20545

DOE/NASA

SATELLITE POWER SYSTEM

Concept Development

and

Evaluation Program

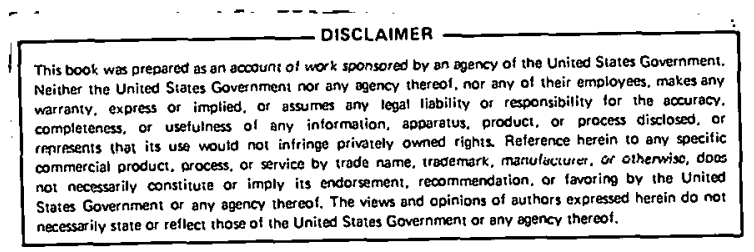

DTSTRIBUTIOA OF THIS ROCOMENT IS UNLIMITEE 
Avallable from:

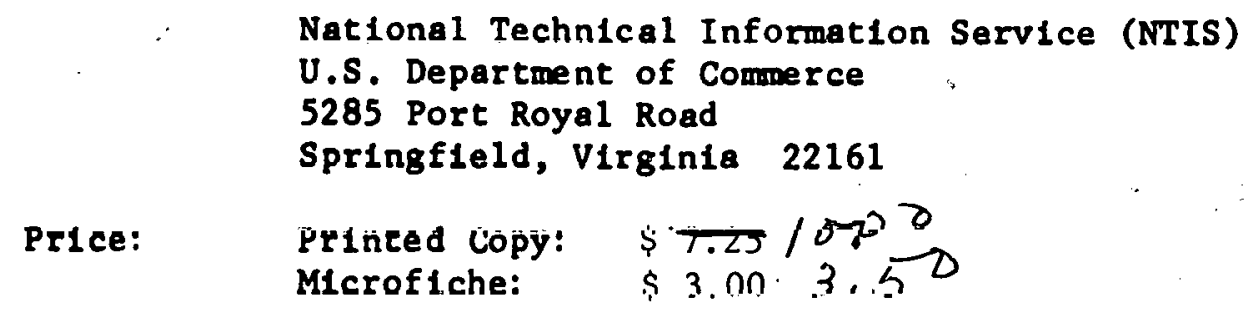




\section{ACKNOWLEDGEMENTS}

The authors would like to express their appreciation to several individuals who agreed to review and critique this report. Their comments represented a valuable contribution to the final product. They are:

Charles Bloomquist -- Planning Research Corporation

Paul Brown -- United Engineers

Hal Goeller -- Oak Ridge National Laboratory

Charles Mundie -- NASA Marshal1 Space Flight Center

Jerry Poradek -- NASA Johnson Spacecraft Center

Andrew Prokopovitsh -- U. S: Bureau of Mines 


\section{SUMMARY AND CONCLUSIONS}

Presently, there are two SPS reference design concepts (one using silicon solar cells; the other using gallium arsenide solar cells). A materials assessment of both systems was performed based on the materials lists set forth in the DOE/NASA SPS Reference System Report: "Concept Development and Evaluation Program."(1)

This listing identifled 22 materials (plus "miscellaneous and organics) used in the SPS. Tracing the production processes for these 22 materials, a total demand for over 20 different bulk materials (copper, silicon, sulfuric acid, etc.) and nearly 30 raw materials (copper ore, sand, sulfur ore, etc.) was revealed.

Assessment of these SPS material requirements produced a number of potential material supply problems. The more serious problems are those associated with the solar cell materials (gallium, gallium arsenide, sapphire, and solar grade silicon), and the graphite fiber required for the satellite structure and space construction facilities. In general, the gallium arsenide SPS option exhibits more serious problems than the silicon option, possibly because gallium arsenide technology is not as well developed as that for silicon.

The table on the next page sumarizes potentlal material problems that have been identified. Problems of serlous concern are denoted by an " $A$ " in the table, and those of lesser but possible concern are denoted by a "B". The "A" materlals are discussed briefly below. For more complete discussions including the " $B$ " materials the reader is referred to Section VI of this report.

As shown in the table, the gallium required for solar cells in the gallium arsenide represents a potentially serious problem from a number of standpoints. It is a by-product of aluminum ore (bauxite) much of which is imported. It is also a high-cost material for which the SPS would be the primary consumer. This last problem could be alleviated if concurrent development of terrestrial photovoltalc programs or other uses for gallium emerged. However, this would also drive up the demand for what would be an already scarce comodity. The 
SUMMARY OF ASSESSMENT RESULTS

\begin{tabular}{|c|c|c|c|c|c|c|}
\hline PARAMETER & $\begin{array}{l}\text { PERCENT } \\
\text { SUPPLIED } \\
\text { AS } \\
\text { BY-PRODUCT }\end{array}$ & $\begin{array}{l}\text { WORLD } \\
\text { PRODUCTION } \\
\text { GROWTH } \\
\text { RATE }\end{array}$ & $\begin{array}{l}\text { SPS } \\
\text { PERCENT } \\
\text { OF } \\
\text { DEMAND }\end{array}$ & $\begin{array}{l}\quad \text { NET } \\
\text { PERCENT } \\
\text { IMPORTED }\end{array}$ & $\begin{array}{l}\text { PERCENT } \\
\text { WORID } \\
\text { RESOURCE } \\
\text { CONSUNPTION }\end{array}$ & $\begin{array}{l}\operatorname{cosT} \\
\$ / K T\end{array}$ \\
\hline THRESHOLD VALUE * & $50 \%$ & $10 \%$ & $.10 \%$ & $50 \%$ & $200 \%$ & $\$ 50 / \mathrm{KW}$ \\
\hline Gallium & A & A. & $A$ & A & & \\
\hline Graphite Fiber & & $A$ & A & & & A \\
\hline Sapph1re & & A & A & & & $A$ \\
\hline SIIICON SEG & . & A & A & . & & A \\
\hline Gàllium Arsenide & & A & $A$ & , & & A \\
\hline Electricity & & - & & & - & A \\
\hline $\begin{array}{l}\text { Arsenic/Arsenic } \\
\text { Trloxide }\end{array}$ & $\mathbf{B}$ & & & B & . & \\
\hline Kapton & & B & B & & r & \\
\hline Oxygen ( $(1 q)$ & & $\dot{B}$ & B & & & \\
\hline Silica Fiber & & B & B & & & \\
\hline silver & B & , & & B & & , \\
\hline Silver ore & & & & B & B & \\
\hline Glass, borosil. & & & B & & & \\
\hline Hydrogen (11q). &. & B & & & 2 & . \\
\hline Mercury & & & & B & & \\
\hline Mercury ore & $\therefore$ & & & B & & \\
\hline Methane & & B & & ; & & \\
\hline Potroleum & & & & & & B \\
\hline St cel &. & & & & & B \\
\hline Tungsten & & & & B & & \\
\hline
\end{tabular}

Note: "A" signifies problem of serious concern

"B" signifies problem of possible concern

*Parameter value above which a potential problem exists. Materials in this table exceeded these values where an " $A$ " or " $B$ " is recorded. 
production of gallium arsenide is also a problem 1n that 1t would need to be greatly expanded and the SPS would again be the dominant consumer. Also, the arsenic and arsentc trioxide needed to produce gallium arsenide represent additional problems due to the weak position of the U.S. arsenic Industry (only one plant in operation). Synthetic sapphire used as the substrate for gallium arsenide solar cells is extremely expenstve. The SPS program would require major production expanston and would become the primary consumer.

The cost and energy requirements (electricity) assoclated wh th the production of solar grade silicon has been and remalns a significant problem. In addition, the SPS again would dominate the market, unless parallel terrestrial photovoltalc programs or other applications for high purtty sllicon were developed. Additional demand would have less impact on silicon than on gallium since the raw material is plentiful. However, it would compound production growth rate problems for the high purity material.

The production of photovoltaic materials requires large amounts of electrical energy. In the case of silicon the energy requirements is so large a silicon solar power satellite would need to operate at least flve to six months fust to generate enough electricity to make the amount of solar grade sllicon used in 1ts solar cells. For gallium arsentde the problem is less severe but possibly only because its defined production process is advanced state-ot-the-art, while the s111con process is present or near-term state of the art. It is $11 \mathrm{kely}$ that the high dollar cost and high energy cost of solar materials is interrelated and when one problem is solved, so will the other.

The only problems of serious concern involving a material that appears in both SPS reference concepts are those assoclated with graphite fiber production. The production growth rate required to meet the comblned requirements of the SPS and expected increased demand by the automoblle Industry could be in the 20-30 percent range sustained for a decade or more. Also, depending on the type of flber selected, graph1te fiber could become one of the highest materlal cost contr1butors to the SP.S. 
In all; potential problems were identified for some 20 SPS materials. Further investigations are needed to determine the severity and implications of these problems and to Identify and define corrective actions. These investigations will need to consider factors such as the accuracy of resource and reserve estimates, improved raw material acquisition and beneficiation techniques, improved material production processes, materials acquisition/production economics (such as price) demand elasticity, capital investment requirements, and byproduct/ co-product economics), and strategies to alloviate import dependency. In addition, the SPS materials characterization (materials 11st) used in this study is incomplete and lacks adequate traceability. A more complete characterization is needed that would improve confidence in analys1s results. 
I - INTRODUCTION. . . . . . . . . . . . . . . . . . . . . . 1

II - MATERIALS ASSESSMENT METHODOLOGY . . . . . . . . . . . . . . . 3

Step 1. Identify Materials Requirements . . . ........... . 6

Step 2. Specify Program Scenario. . . . . . . . . . . . . 6

Step 3. Compute Annual Materials Requirements . . . . . . . . 6

Step 4. Analyze Material Production Processes . . . . . . . . . . 7

Step 5. Characterize the Materials Industry . . . . . . . . . . 7

Step 6. Assess the System's Impact. . . . . . . . . . . . . . 7

Step 7. Analyze the Results . . . . . . . . . . . . . . 7

Step 8. Study Alternative Options. . . . . . . . . . . . . . 8

III - SPS MATERIALS REQUIREMENT . . . . . . . . . . . . . . . . . 10

IV - SPS MATERIALS SCREENING . . . . . . . . . . . . . . . 17

Materials Screening . . . . . . . . . . . . . . . 17

CMAP Program Operations . . . . . . . . . . . . . 17

Bulk Materials Screening . . . . . . . . . . . 18

Raw Materials Screening ................. . 21

CMAP Screening . . . . . . . . . . . . . . . . . . . 23

V - ANALYSIS OF RESULTS . . . . . . . . . . . . . . . . . • 36

By-Product Problems . . . . . . . . . . . . . . 36

By-Products/Co-Products of No Concern . . . . . . . . . 36

By-Products/Co-Products of Possible Connern . . . . . . . . 38

By-Products/Co-Products of Serious Concern. . . . . . . . . 39

By-Products/Co-Products - Not "Flagged" But of Possible Concern 39

Production Capacity/System Market Demand Problems . . . . . . . . . 40

Nátural Gas (Methane)/Hyarogen/Oxygen . . . . . . . . . . . . . 44

Resource Depletion Problem. . . . . . . . . . . . . . . 46 
TABLE OF CONTENTS

(Continued)

Page

Import Dependency Problems. . . . . . . . . . . . . . . 47

Material Cost Problems. . . . . . . . . . . . . . . 50

Percent World Supply From One Nation, Non-U.S.. . . . . . . . 54

VI - SPS Critical Materials Summary . . . . . . . . . . . . 57

Material Problems of Serious Concern . . . . . . . . . . . . . 57

Material Problems of Possible Concern . . . . . . . . . . . . 64

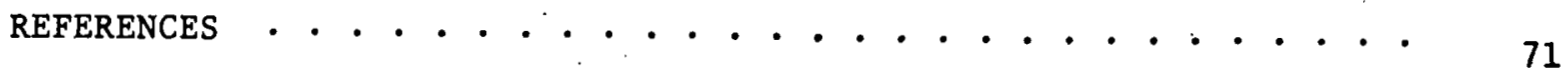

LIST OF APPENDICES

APPENDIX A. MATERIALS DATA BASE. . . . . . . . . . . . . . . . A-1

APPENDIX B. DISCUSSION OF RESERVES AND RESOURCES . . . . . . . . . . . . B-1

\section{LIST OF FIGURES}

FIGURE 1. THE MATERIALS CYCLE. . . . . . . . . . . . . . . 3

FIGURE 2. TYPICAL CONVERSION CHAIN OR MATRIX . . . . . . . . . . 4

FIGURE 3. OVERVIEW OF THE METHODOLOGY. . . . . . . . . . . . . . 5

FIGURE B-1. CLASSIFICATION OF MINERAL RESOURCES. . . . . . . . . B-2

FIGURE B-2, BAUXITE AVAILABILITÝ . . . . . . . . . . . . . . B-3

\section{LIST OF TABLLS'}

TABLE 1. MATERIALS LIST FOR REFERENCE SYSTEM. . . . . . . . . . 11

TABLE 2. MATERIALS FOR INITIAL 5 GW SṖS AND SUBSEQUENT SYSTEMS. • . 15

TABLE 3. BULK MATERIAL REQUIREMENTS FOR SOLAR POWER

SATELLLITE DEVELOPMENT (SILICON) . . . . . . . . . .' 24

TABLE 4. RAW MATERIAL REQUIREMENTS FOR SOLAR POWER

SATELLITE DEVELOPMENT (SILICON). . . . . . . . . . 
TABLE OF CONTENTS

(Continued)

$\underline{\text { Page }}$

TABLE 5. BULK MATERIAL REQUIREMENTS FOR SOLAR POWER

SATELLITE OPERATIONAL SYSTEM (SILICON). . . . . . . . . .

TABLE 6. RAW MATERIAL REQUIREMENTS FOR SOLAR POWER

SATELLITE OPERATIONAL SYSTEM (SILICON). . . . . . . . .

TABLE 7. BULK MATERIAL REQUIREMENTS FOR SOLAR POWER

SATELLITE DEVELOPMENT (GA/AS) . . . . . . . . . . . 30

TABLE 8. RAW MATERIAL REQUIREMENTS FOR SOLAR POWER

SATELLITE DEVELOPMENT (GA/AS) . . . . . . . . . . . . .

TABLE 9. BULK MATERIAL REQUIREMENTS FOR SOLAR POWER

SATELLITE OPERATIONAL SYSTEM (GA/AS). . . . . . . . 33

TABLE 10: RAW MATERIAL REQUIREMENTS FOR SOLAR POWER

SATELLITE OPERATIONAL SYSTEM (GA/AS). . . . . . . . . 35

TABLE 11. PERCENT SUPPLIED AS BY-PRODUCT. . . . . . . • . . . . . . 37

TABLE 12. CAPACITY/MARKET FACTORS OF CONCERN. . . . . . . . . . . 41

TABLE 13. WORLD RESOURCES - PERCENT CONSUMED BY 2029 AND SPS DEMAND • . 46

TABLE 14. RAW MATERIAL IMPORT DEPENDENCY FACTORS PERCENT

U.S. IMPORTS. . . . . . . . . . . . . . . . . . 48

TABLE 15. BULK MATERIAL IMPORT DEPENDENCY FACTORS OF CONCERN.

PERCENT U.S. IMPORTS 1976 . . . . . . . . . . . . .

TABLE 16. BULK AND RAW MATERIALS VALUES EXCEFITTNG

$\$ 50.00$ PER KW INSTALLED . . . . . . . . . . . . . 51

TABLE 17. PERCENT OF WORLD SUPPLY FROM ONE NON-U.S. NATION. . . . . 55

TABLE 18. SUMMARY OF ASSESSMENT RESULTS . . . . . . . . . . . . . . 58

TABLE A-1. BUík MATERLAL DATA SUMMARY. . . . . . . . . . . . . . A-2

TABLE A-2. RAW MAILRIAL DATA SUMLARY ................. . . A-6

TABLE A-3. ENGINEERING TO BULK CONVERSIONS . . . . . . . . . . . A-8

TABLE A-4. BULK MATERIAL PRODUCTION PROCESSES. . . . . . . . . . . . A-13 


\section{I - INTRODUCTION}

Major new energy systems being studled to replace or supplement fossil-fuel systems will have significant impacts on soclety, Industry, and various sectors of the economy. Some of these systems require huge amounts of land. Some of these systems require heavy capital

investments. In many cases, international agreements may be necessary, often with military implications.

As a result of these potential 1mpacts, there are many factors that require careful attention in considering new systems. Societal Impacts, economic effects, and environmental concerns must be weighed, together with the 1ssue of public acceptance. Governmental regulations, buflding codes, and other institutional factors also require close scrutiny. Of major importance among these many concerns is consideration of materials requirements. Vast quantities of materials can be needed-some of them rare, others costly, many already in heavy demand. The proposed 300-gigawatt Satellite Power System (SPS)(1) could require almost 900 million metric tons of bulk materials (ranging from the common, such as sand and gravel, to the rare or exotic, such as gallium arsentde).

The primary objective of this study was to explore the materials requirements of the SPS to Identify potential materials problems and constraints so that approprlate responsive action could be defined and incorporated 1nto overall. SPS planning. The approach was to determine SPS materials requirements as Identifled by DOE/NASA studies (1) and assess the Impacts of those requirements using the Battelle Materials Assessment Methodology.(2) The methodology consists of two basic elements: ( 1 ) an extensive materials data base that contains information defining the present and future avallability of materials; and (2) a computer program (Critical Materials Assessment Program -CMAP) that computes system (1.e., the SPS in this study) material. requirements over time, compares requirements. with avallability (data

\footnotetext{
*Superscript numbers refer to references at the end of this report.
} 
base), and flags potential problems or constraints. The results thus generated were revlewed and analyzed to determine the significance and serlousness of identified problems and to recommend appropriate action.

Prior to the conduct of the SPS assessment it was decided (by the Department of Energy and Battelle) to upgrade the computer program (CMAP) and the data base to assure the adequacy of present and future SPS materials studies and similar studies of other systems. CMAP was modifled to provide automated tracing of production processes and chains of production processes so that materials required in intermediate production steps would be included in the asecosment. Other modifications were instituted that relaxed previous constraints as to the time span that could be considered and the manner in which materlal demand could be spectfied. Previous analyses were Ifmited to cases where the time period of interest did not extend beyond the year 2000, and where the growth of materlal demand occurred exponentially. The CMAP modifications permitted analyses to be extended to 2050, and allowed for the study of any arbitrary material demand growth function.

The entire data base was thoroughly reviewed and upgraded. The data base construction effort encompassed not only materlals expecter to be required for the SPS bur also materials required for other systems (e.g. terrestrial photovoltaic systems and solar heating and cooling of buildings-SHACOB systems). The broader data base will be required for planned future comparative studies in which the material requirements of the SPS will be compared with alternative systems' such as coal or nuclear power generating plants.

When the CMAP and data base modtficationo were completed the SPS materials assessment was ennductud. This report focuses on that assessment. MAP and the data base will be discussed only as necessary to clarify the SPS assessment. However, the entire data base is presented in Appendix A. 


\section{II - MATERIALS ASSESSMENT METHODOLOGY}

One usually thinks of the flow of materlals proceeding from raw materials to the final materials (Figure 1).(2) Take for example, çopper. Copper ore 18 mined and sent to a mill and smelter. The bulk materlal, copper, that leaves this process may be formed into a final englneering material like brass (an alloy of copper and zinc). This brass may then be machined and fabricated into hardware components for the SPS or some other system. The tracking process needed in a materlals assessment follows the opposite direction. First, the amount of brass in the system being studled must be determined. Then this is translated into its bulk materials, one of which is copper. At this point the bulk materlal copper would be reviewed for possible capacity constraints. Next the copper production process would be analyzed and

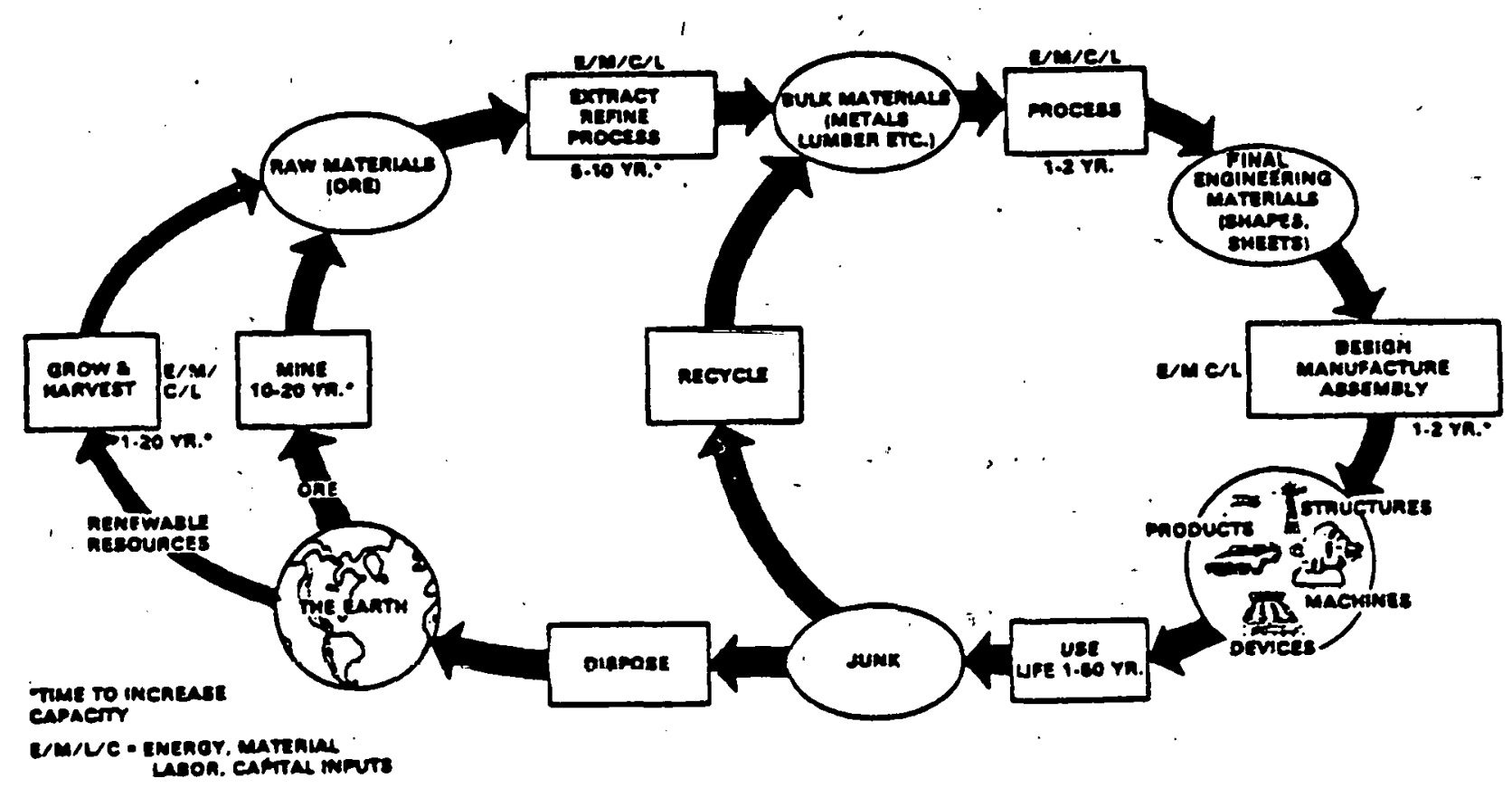

FIGURE 1. THE MATERIALS CYCLE 
Its material needs identifled: "copper ore, sulfuric acid, steel, electricity, coal, etc. The copper ore and all of the other bulk* and raw materials are then checked for potential capacity constraints and for avallability of reserves and resources. Figure 2 describes the foregolng relationships graphically. The production of these secondary. materlals must also be analyzed to complete the materials assessment. This analysis logic could conceivably proceed on through several additional steps but in practice is terminated after two additional

RAW MATERIALS

AND SECONDARY

BULK MATERIALS

FINAL

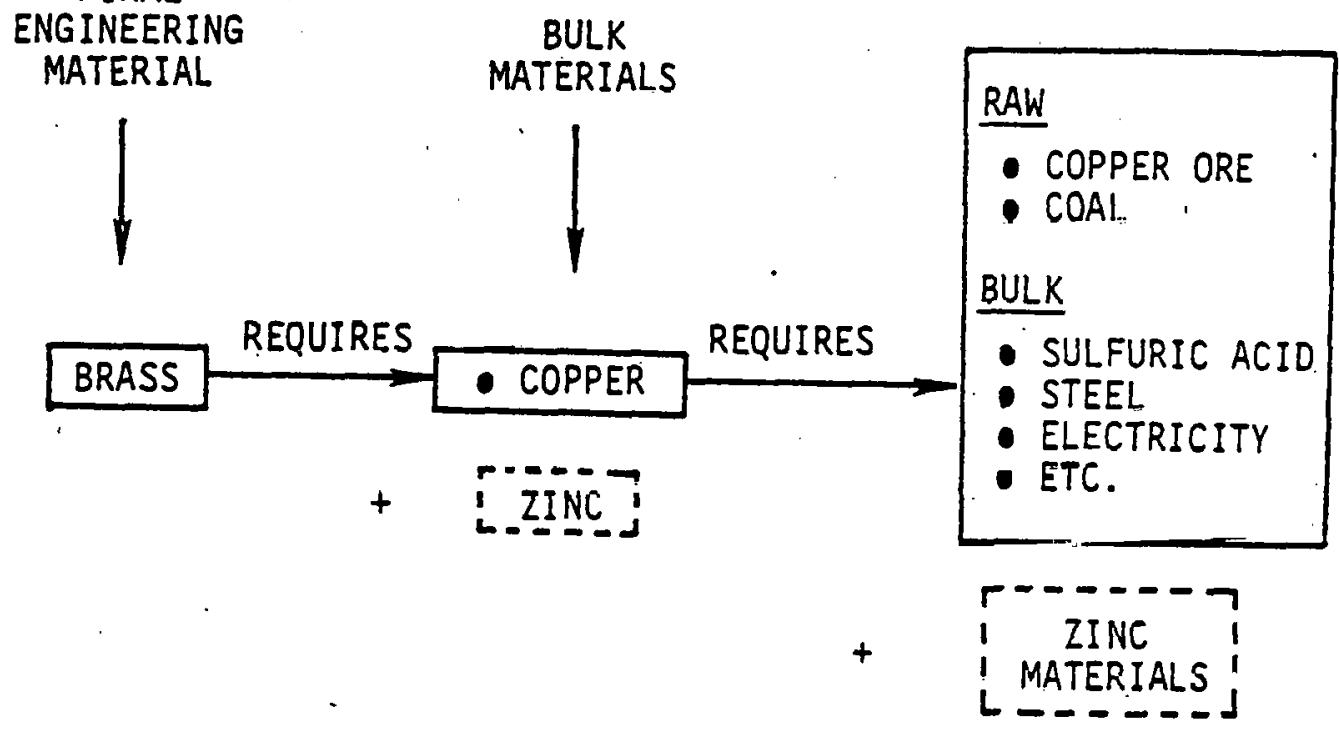

FIGURE 2. TYPICAI CONVERSION CHAIN OR MATRIX

* Bulk materlals required to produce other bulk materials (e.g. sulfuric acid required to produce copper) are referred to as "secondary" bulk materials. 


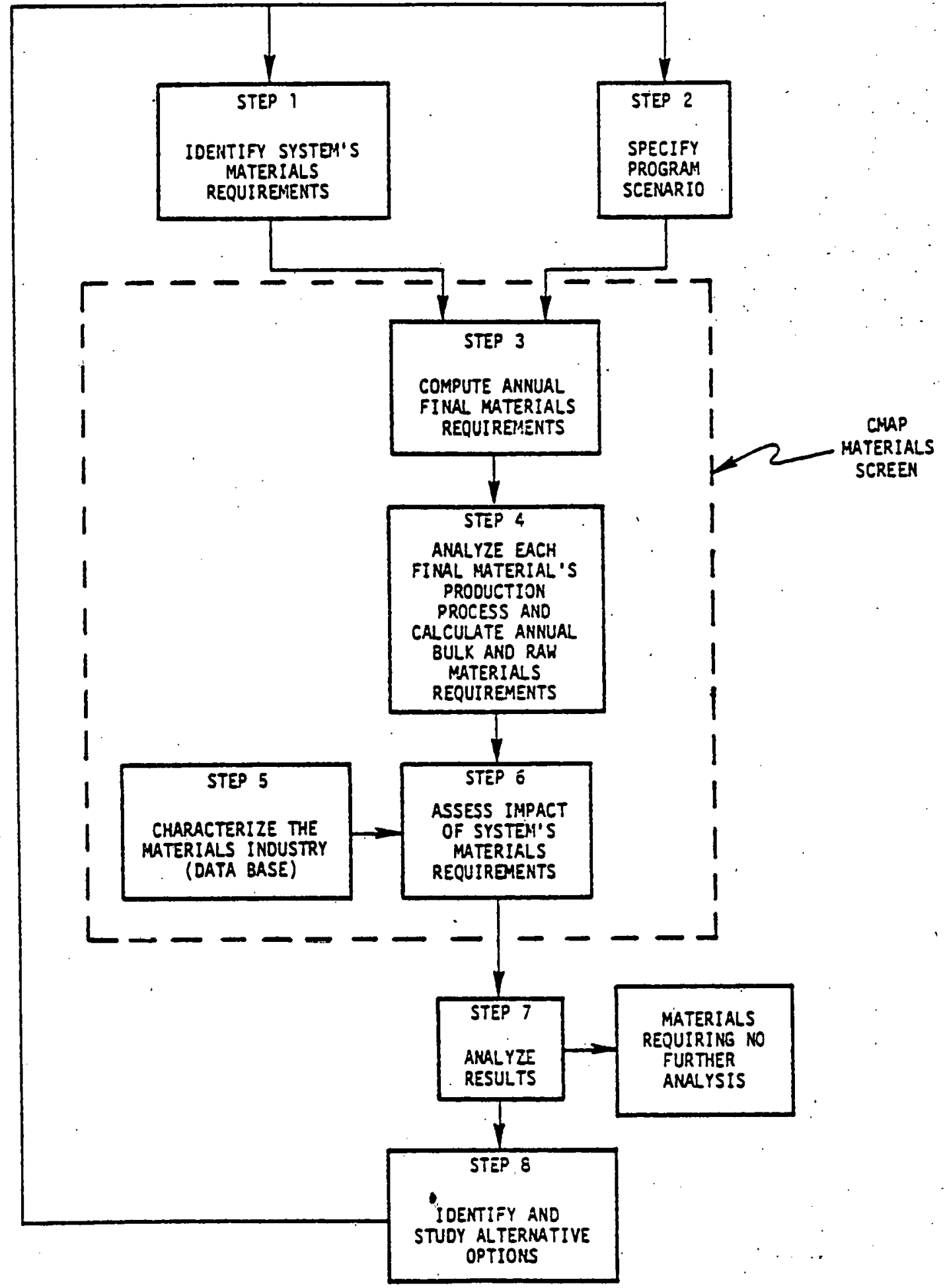

FIGURE 3. OVERVIEW OF THE METHODOLOGY 
steps. At that point many production chains are complete and material quantities required for additional steps are generally insignificant. When the above simplified example is expanded to a overall materials assessment of a total system such as the SPS, the problem becomes wuch more complex, involving large numbers of materials and production processes. The analysis required can best be described as consisting of the following eight basic steps: (refer aiso to figure 3

\section{Stcp 1. Idencify Materials Requirements}

The final construction materials. (such as brass, concrete, composites, or solar-grade silicon) for a system under study, are 1dentified, preferably at the component or subsystem level. In addition, any expended materials (eig. fuels) needed in the construction or operation of the system are also identified. This results in a listing of the quantities of all materials required for the construction, installation and operation of one system "unit" (such as one solar power satellite and its earthborn equipment, or one coal-fired generating plant) producing a specified amount of energy.

\section{Step 2. Specify Program Scenario}

A "scenario" is a statement of a system's ultimate size and the timing of its construction. The scenario gives the number of system units to be constructed per year for each year of the program's duration. The SPS scenario, for example, specifies two satollite units per year throughout the period from 2000 to 2029 , for a total of 60 unies each developing 5 gigawatts output. Thus the total power output at program completion would be 300 gigawatts.

\section{Step 3. Compute Annual Materials Requirements}

The annual materials requirements are calculated by multiplying the units per year by the quantities of each final material in one unit. 
Step 4. Analyze Material Production Processes

Each final constriction material is produced from bulk and secondary bulk materials* (such as copper, cement, graphite fiber, or sulfuric acid) and raw materials (such as sand and gravel, ore, or timber). Quantities of all such materials are calculated by year.

\section{Step 5. Characterize the Materials Industry}

For all materials, a data base is developed. It includes such factors as availability, source, production capacity, expected growth in demand, and prices on a domestic and worldwide basis for each material.

\section{Step 6. Assess the System's Impact}

The system's annual demand for each material (as determined in Steps 1-4) is compared to pertinent information in the data base for that material. This reveals the impacts of the system, expressed in such terms as percentage of total production required, percentage of raw. material resources and reserves consumed*, or dependency on imports.

\section{Step 7. Analyze the Results}

The significance of each impact identified in Step 6 is assessed by comparison to a predetermined threshold value. Some impacts will be of no concern; others will require further study.

* As noted earlier, bulk materials required to produce other bulk materials (e.g. sulfuric acid required to produce copper) are referred to as "secondary" bulk materials.

**For a given raw material, the term resource is defined to be an estimate (usually by the U.S. Bureau of ilines) of the total naturally occurring in situ deposits of that material. The term reserve is. defined as that portion of the resource that is located in identified deposits and can be economically extracted given current technology and aineral prices. See Appendix B for additional explanation. 


\section{Step 8. Study Alternative Options}

For those materials involving significant uncertainties, or potential constralnts, alternative options are identified and studied. One option is materials substitutions. If this is considered, Steps 1 through 7 are repeated to evaluate the effect of the substitution. Other options open to nanagers and planners for reducing uncertainties include redestgning a component, subsystem, or an entire system; undertaking R\&D aimed at alleviating an uncertainty; exploring for new resources; or developing incentives for expanding manufacturing capacity. Steps 3 through 6 have been automated by developing a computerIzed analysis program and a comprehensive data base of information on materials and the materials industry.

The analysis program is known as the Critical Materials Assessment Program (CMAP) and its functions are those enclosed by the dashed line in Figure 3. CMAP can accumulate all requirements for a given material regardless of the ultimate usage of that material in a system. It can give the bulk and raw constituents of a material; calculate the impacts of a system's materials requirements relative to worldwide availability, source, demand, etc.; screen out materlals that are of no concern; and identify those that are of concern.

The data base currently contains about 2000 data entries covering more than 260 materials. Bulk material information includes esti-

mates of present and future U.S. and world consumption, prices, U.S. Imports, and dominant non-U.S. suppliers. Information on raw materials includes the same kind of data plus estimates on U.S. and world reserves and resururies.

The information base also includes data on the consumption of primary (including by-products), secondary, and tertiary materials required to produce each unit of standard bulk material. Over 100 infortation sources have been employed. The sources include many government publications, technical handbooks, special reports, technical papers, trade association and technical association data, journal articles and the like. Where no secondary source data are 
available, information has been obtained directly from producers. Data entries are referenced for further examination when necessary. A partial listing of references used is included in the reference list at the end of this report (3-25).

Application of the assessment methodology to the SPS is the subject of the next four sections of this report. As indicated in Figure 3, the input requirements for the CMAP analysis of the SPS are a listing of final materials used (those identiflable in the system hardware, plus expendables such as rocket propellants), and a specification of the SPS program scenario. These inputs are defined in Section III. The CMAP automated materials screen is discussed in Section IV. This section includes definition and discussion of the CMAP output format and interpretation of results. The SPS assessment is. completed with analysis of screening results in Section $v$, and $a$ concluding summary of the assessment (Section VI).

It should be noted that in this preliminary assessment only minimal attention has been given to the study of alternative options or mitigating strategies to deal with identified material problems (Step 8 in the methodology). In most cases, additional study is needed to. determine the severity of identified problems before it will be known where mitigating strategies may be needed. 
III - SPS MATERIALS REQUIREMENT

The present reference design concepts (one using silicon solar cells; the other using gallium arsenide solar cells) consist of six main elements. These are:

(1) Satellites placed in geosynchronous earth orbit (GEO) and consisting of photovoltaic arrays and microwave power conversion and transmission equipment.*

(2) Ground antennas for recelving mlcrowave transmissions and equit.pment for converoion to $\Lambda C$ power and ullilty Interfacing.

(3) Launch vehicles for transporting cargo and personnel into. low earth orbit (LEO).

(4) Facilities and equipment in LEO for fabricating and assembling satellite hardware and support equipment.

(5) Orbital transfer vehicles (OTV's) for transferring cargo and personnel. to GEO.

(6) Facilities for constructing the satelites in GEO.

To perform the materials assessment, the material requiremencs* of these system elements must be identified, p'referably at the subsystem level. However complete subsystem level material specifications for the SPS reference designs do not exist at present. In lieu of complete specification, the materials list published in the SPS reference design document (1) published by NASA was used in this study (see Table 1). This listing 1dentifies twenty-two materials (plus "miscellaneous and organics") used in the various SPS elements.

\footnotetext{
*Electrical energy generated by the photounltaic array would bc converted to microwave energy on board the satellite and transmitted to Earth.

**i.e. the final englneering and finished bulk materials identifiable in finished SPS components:
} 
Table 1. Materfals List for Reference System

RESOURCE REQUIREMENTS (METRIC TONS)

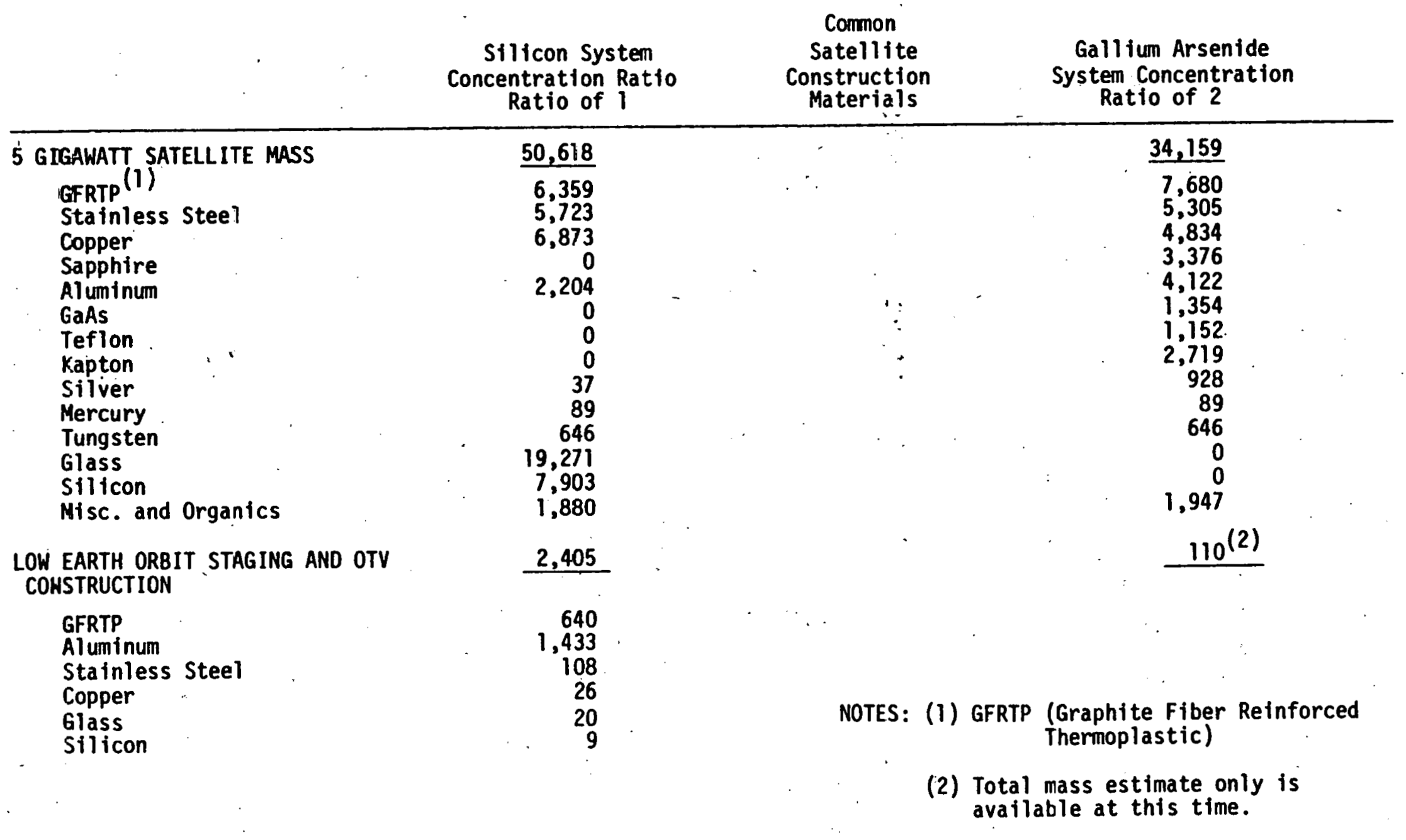


(continuation) Table 1. Matertals List for Reference System

RESOURCE REOLIIREMENTS (METRIC TONS!

\begin{tabular}{ccc}
$\begin{array}{c}\text { Silicon System } \\
\text { Concentration Ratio } \\
\text { Ratio of 1 }\end{array}$ & $\begin{array}{c}\text { Cormon } \\
\text { Satellite } \\
\text { Construction } \\
\text { Materials }\end{array}$ & $\begin{array}{c}\text { Gallium Arsen } \\
\text { System Concentr } \\
\text { Ratio of } 2\end{array}$ \\
\hline$\frac{8,353}{2.55]}$ & & $\underline{6,000(2)}$ \\
4,694 & $\vdots$ & \\
390 & & \\
110 & & \\
30 & & \\
13 & & \\
565 & &
\end{tabular}

HEAVY LIFT LAUNCH VEHICLE (HLLV)

$\underline{1,170}$

Aluminum

Titanium

Stainless Steel

Ceramic

Copper

Misc. and Organics

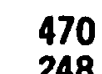

248

232

103

100

PERSONNel LAUNCH VehICLE (PLV)

Aluminum

Titanium

Stainless Steel

Ceramic

Copper

Misc. and Organics

$\underline{264}$

106

56

52

23

23

PERSONNEL ORBITAL TRANSFER VEHICLE (PORTV)

116

Aluminum

Stainless Steel

81

Copper

Misc. and Organics

23

2

10 
(continuation) Table 1. Materials List for Reference System RESOURCE REQUIREMENTS (METRIC TONS)

\begin{tabular}{|c|c|c|}
\hline $\begin{array}{c}\text { Sllicon System } \\
\text { Concentration Ratio } \\
\text { Ratio of } 1\end{array}$ & $\begin{array}{c}\text { Common } \\
\text { Satellite } \\
\text { Construction } \\
\text { Materials }\end{array}$ & $\begin{array}{l}\text { Gallium Arsenide } \\
\text { System Concentration } \\
\text { Ratio of } 2\end{array}$ \\
\hline
\end{tabular}

\begin{tabular}{lr}
\hline CARGO ORBITAL TRANSFER VEHICLE (COTV) & 1,100 \\
\hline Aluminum & 3 \\
GaAs & 0 \\
Teflon & 0 \\
Sapphire & 0 \\
Kapton & 0 \\
GFRTP & 126 \\
Copper & 67 \\
Silicon & 256 \\
Stainiess Steel & 14 \\
Glass & 623 \\
Misc. and Organics. & 11
\end{tabular}

\begin{tabular}{r}
679 \\
\hline 369 \\
38 \\
32 \\
93 \\
66 \\
0 \\
15 \\
17 \\
40 \\
0 \\
9
\end{tabular}

RECTENNA

Steel

Concrete

Aluminum

GaAs

$$
\begin{array}{r}
1,492,000 \\
1,330,000 \\
140,000 \\
9
\end{array}
$$


From Table 1(1) the "unit" materials demand (1.e. the materials required for one satellite, one ground rectenna, etc.) can be determined. To determine total demand the SPS program scenario must be spectfied--the number of satellites/rectennas to be constructed as a function of time. The present reference SPS program consist of two phases: a developmental phase, and an operational phase. The SPS development would begin in 1986 and culminate in the completion of the flrst $J$ glgaware (GW)* satellite/rectenna system in the year 2000 . The operational phase would commence with the completion of a second 5GW system in 2000 and continue with the: completion of two systems each year thereafter through the year 2029. Thus a total of 60 5GW systems ( 300 GW total power output) would be installed-5GW at the end of the development phase and 295GW during the operational phases.

Based on this scenario and the SPS unit material requirements NASA determined the total requirements for the developmental and operational phases to be as shown in Table 2.(1)

The materials listing in Table 2 was then the basis for the SPS materials screening and analyses that follow in subsequent sections of this report.

*5 gigawatts delivered to the power grid. 
Table 2. Materials for Initial 5 GW SPS and Subsequent Systems

(UNITS IN METRIC TONS)

\begin{tabular}{|c|c|c|c|c|}
\hline \multirow[b]{2}{*}{ SATELLITE PROGRAM MATERIALS } & \multicolumn{2}{|c|}{ Through First 5 GW SPS } & \multicolumn{2}{|c|}{ Two 5 GW Satellite/Year } \\
\hline & Si & $\mathrm{Ga}$ & si & $\mathrm{Ga}$ \\
\hline GFRTP. & 12,447 & 7,680 & 12,716 & 15,360 \\
\hline Stainless Steel & 7,621 & 6,511 & 11,446 & 10,610 \\
\hline Glass. & 33,650 & 0 & 38,542 & 0 \\
\hline Sillicon & 13,813 & 0 & 15,806 & 0 \\
\hline Copper & 8,630 & 5,030 & 13,746 & 9,668 \\
\hline Aluminum & 150,654 & 149,227 & 284,408 & 288,244 \\
\hline Silver & 37 & 928 & 74 & 1,856 \\
\hline Mölybdenum & 2 & 0 & 4 & 0 \\
\hline Mercury & 89 & 89 & 178 & 178 \\
\hline Tungsten & 646 & 646 & 1,292 & 1,292 \\
\hline Steel & $1,492,000$ & $1,492,000$ & $2,984,000$ & $2,984,000$ \\
\hline Concrete & $1,330,000$ & $1,330,000$ & $2,660,000$. & $2,660,000$ \\
\hline Gallfum Arsenide & 7 & 1,696 & 14 & 2,708 \\
\hline ritanfum & 1,104 & $\therefore 856$ & 248 & 124 \\
\hline Ceramics & 458 & 355. & 103 & 52 \\
\hline Misc. and Organtcs & 3,084 & 8,663 & 3,700 & 3,984 \\
\hline Argon & 20,559 & 4,876 & 18,690 & 4,664 \\
\hline $\mathrm{H}_{2}$ & 107,406 & 61,227 & 128,547 & 80,920 \\
\hline
\end{tabular}


(Table 2 continued)

Through First 6 GH SPS

$S 1$
$2,268,033$
540,572
0
0
0

Fro 5 GH Satellite/Year

$\begin{array}{rrr}s 1 & & \text { Ga } \\ & & 1,680,710 \\ 651,599 & 379,930 \\ 0 & & 6,752 \\ 0 & \cdots & 2,306 \\ 0 & & 5,438\end{array}$

Note 1: Material masses through the first 5 GW SPS Include:

a. Three Heavy Lift Launch Venfcles

b. Two Personnel Launch Vehtcles

c. Two Personnel Orbital Transfer vehtcles

d. Twenty-three Cargo Orbital Transfer Vehicles for s1licon satell1te or

e. Nine Cargo Orbital Transfer vehicles for gallium arsenide satellite

f. One geosynchronous orbit construction base

g. One low earth orbit staging and orV construction base

h. Fuel for all required fights

Note 2. Material masses for two $5 \mathrm{GW}$ satell1te/year columns includes only the two satellites, rectennas and fuel required for al1 f1 lghts necessary for both satel: 1 tes to become operational. 


\section{IV - SPS MATERIALS SCREENING}

Assessment of materials requirements with the ald of the Critical Materlais Assessment Program (CMAP) is basically a two step process. First, total program materlals requirements are screened, using CMAP, to determine which requirements represent potential problems. Second, potential problems are analyzed to determine severity and the need for additional action.

\section{Materials Screening}

\section{CMAP Program Operation}

MAP performs three princlpal functions: (1) calculation of total materials requirements; (2) determination (for each material) of a set parameters that characterize the materials demand impact; and, (3) comparison of the parameter values so determined with certain "threshold" values for those parameters, which, when exceeded, signify potential problems. When threshold values are exceeded; "flags" are set on the output printout that call attention to the potential problem. Calculation of materials requirements begins with the SPS materials list presented in Section III (Table 2). Total amounts of the 22 materials on that 11st required to support the specified (In Section III) SPS program scenar1o are calculated. Then, using information stored in the materials data base, production processes required to produce those 22 materials are analyzed to determine secondary bulk materlal and raw material requirements. The results, which will be presented later, were a demand for over 50 different bulk materlals (copper, silicon, sufuric actd, etc.), and nearly 30 raw materials (copper ore, sand, sulfur ore, etc.).

Once total materials demand has been established attention turns to the material parameters and threshold values on which the screening is based. Since the parameters of interest and threshold values differ somewhat for bulk and raw materials, the-screening of 
these two types of materials is done separately (separate output

printouts are produced).

Before proceeding with a general discussion of the screening, a few additonal words regarding the threshold values used are in order. One of the parameters of interest for bulk materials is the production growth rate required to meet the demand of the SPS and all other industries (retrievahle from the materialo data base). The threshold value for this parameter is currently set at $10 \%$ per year. Thus, if the required growth rate exceeds $10 \%$ a $f 1$ ag is set on the printout signifyIng that a potential production capacity problem exist. If the material In question has a relatively small production base (e.g. graphite reinforced thermoplastic) then a $10 \%$ growth rate might not be difficult to achleve. However, if the material in question already has a large production base (e.g. aluminum) then a $10 \%$ growth rate would represent an enormous requirement for additonal capital, labor, facilities, etc., and a definite problem exists.

Thus, in real1ty, an accurate "threshhold value" for a given parameter might be different for each material considered. However, any attempt to incorporate this reality into CMAP would make the automated screeuluy Incractable and defeat its entire purpose. Therefore a single threshold value is postulated for each parameter--a value, based on Battellefs materials assessment experience, that is representative and generally conservative for the majority of materials. These,threshold values are not intended to be absolute measures of material criticality, but merely indicators that can speed and simplify the analysis of results. The responsibility for accurately interpreting those results properly remains the task of the experienced anslyat.

\section{Bulk Materials Screening}

The parameters of interest for bulk materlals are listed below. These parameters are determined for each material required.

- Percent of the material which is produced as a by-product of another material production process 
- World production growth rate (per year) required to meet SPS and all other projected demands

- Maximun percent demand (in any given year) of the SPS as a portion of total world demand

- Percent of the world production attributable to a single foreign source

- Material purchase cost contribution to SPS power installed, $\$ / \mathrm{KW}$

- Net percent of U.S. material consumption that is imported (from all foreign sources).

In the following paragraphs these parameters are discussed, the rationale for assessing criticality is developed, and currently used threshold values are identified.

Percent Supplied as By-Product. The threshold value is set here at 50 percent. The frequent implication that by-product dependence is constraining is of ten misleading. Materials sonetimes considered today as by-products may be viewed at other times as co-products or even primary products depending upon supply/demand and market price conditions. Hence the term by-product material should not necessarily be viewed as a "low-cost" or an "undesirable" material production consequence of a process stream. The economics of many extractive and manufacturing proçesses are highly dependent upon by-product/co-product recovery. That economic dependence or leverage frequently becomes important in assessing criticality of the material. Where economic dependence is not present, only strong demand and attractive market prices will bring forth the capital investment required to recover the amounts of the by-product material needed.

Growing demand for the primary product is of basic importance. to sustaining given levels of by-product production. If the system requirements for the by-product material are small, or if the market is "glutted", even declining primary material production levels can maintain adequate by-product supplies. 
World Production Growth Rate. The threshold value here is 10 percent. Many small volume or new materials can readily maintain a 10 percent annual rate of. growth. However large volume, captal intensive commodities would have great difficulty in sustalning such a growth rate. Therefore any growth rate over 5 percent for high volume commodity materials, raw or bulk, should also be reviewed.

Maximum Percent System Demand, One Year World. This threshold is set at 10 percent. This figure represents the system's market impact on material consumption at its potentially highest demand level relative to demand for that materlal for other uses. At high percentaye of demand levels, the system demand can be a market driver, perhaps bring ing about higher prices or even cartelization. This criterion may also be viewed as a trigger for closer examination of opportunity costs-that 1s, the systems potential for adverse impact on other segments of the economy demanding the same materlal.

Percent From One Nation, Non-U.S. This threshold level is set at 35 percent. It represents a measure of supply domination in world markets by any one non-U.S. nation. If the system material demand is also a significant proportion of total demand, then potential for suppiy disruption or cartelization is present. The nature of the material as well as the dominant nation Identified, then becomes a part of the criticality fudgement. This criterion usually assumes more'importance In assessing raw materials, since bulk materlal production among industrial nations tends to disperse over time.

Present Costs in $\$ / \mathrm{KW}$. This threshold is set at $\$ 50.00$ per $\mathrm{KW}$ of constructed capacity. This value is calculated as MT required $x$ per MT/system capacity in KW. Values for material in excess of the $\$ 50.00$ threshold deserve close examination. It should be emphasized that these figures represent present bulk material cost--not the present cost of fabricated components. The fabrication cost of many materials can very substantially exceed the materials cost per se. Stated costs. 
also are representative of the prevailing art for producing the materials--often in low volumes in the case of new materials. For many newer materials, those production costs can be expected to be lowered over time.

Total cost of the system attributable to these materials becomes sensitive to changes in price or required volume of the mater ials in question. Materials price forecasts, fabrication cost determinations, design review and possible materials substitutions might be considered.

Net Percent Imported. The threshold value is set at 50 percent and is based on current levels of net U.S. imports. If the maximum volume of material required by the system is very small compared to total U.S. demand in the same time frame, there is probably little cause for concern regardless of the U.S. import level. For many materials particularly raw materials - for which the U.S. is dependent on imports, that dependency is likely to grow in future years. This is a matter of general economic concern and not necessarily related to any specific system under consideration. In other words, we would be concerned only if the system design and its construction scenario might substantially exacerbate an already recognized U.S. import dependency for certain materials.

Raw Materials Screening. With respect to the screening of raw materials levels of current reserves and resources estimates are introduced as screening parameters, in addition to those identified in the bulk materlal discussion. In general, where the U.S. is reserve/ resource deficient, it is also import dependent. The focus of concern In these cases is levels of world reserves and resources and whether the system construction would substantially contribute to world resource deflclency or to substantially greater U.S. import dependency. The complete list of raw material screening parameters is given below.

- World production growth rate (per year) required to meet SPS and all other projected demands 
- Maximum percent demand (in any given year) of the SPS as a portion of total world demand

- Percent of U.S. reserves consumed by the SPS and all other projected demand

- Percent of U.S. resources consumed by the SPS and all other projected demand

- Percent of world material production attributable to a single foreign source

- Percent of world reserves consumed by the SPS and all other projected demand

- Percent of world resources consumed by the SPS and all other projected demand

- Material purchase cost contribution to SPS power installed, \$/KW

- Net percent of U.S. material consumption that'is imported (from all foreign sources).

The previous discussions of parameters under "Bulk Materials Screening" adequately describe those parameters which are common' to both bulk and raw materials, with the exception of "World Production Growth. Rate", and "Percent from One Nation, Non-U.S.", where the raw material threshold values are different. Therefore those discussions will not be repeated here. World Production Growth Rate and the new U.S. and world reserve and resource parameters are discussed below.

World Production Growth Rate. The threshold value here is 7 percent rather than the 10 percent value used for bulk matcrials. Extractive operations usually require longer lead times and are very capital intensive. Sustained annual growth rates of 5 percent are not too unusual but 7 percent would be.

Percent from One Nation, Non-U.S. The threshold value here is 60 percent rather than the 35 percent value used for bulk materials. Developed resources tend to be more concentrated in specific locations than bulk material production facilities. However, the opportunity to 
exploit undeveloped resources in alternative locations generally exists. Consequently, the higher threshold value is used.

U.S. Reserves and Resources Consumed and World Reserves and

Resources Consumed. The threshold values used are 400 percent, 300 percent, 200 percent and 200 percent, respectively. For the 50-year time span considered, these threshold values are quite conservative (see Appendix $B$ ). One could argue for many material's that they might even comfortably be doubled.: "In analyzing U.S. reserves and resources, sensitivity to doubling those values would be minimal, since we are usually either highly foreign source dependent - or hardly at all. SPS construction would measureably. increase U.S. dependence for only a very few materials. These few materials however are important to SPS. In only one case would SPS significantly consume a world reserve/resource in potentially short supply--namely silver ores.

\section{CMAP Screening}

CMAP was used to screen the materials requirements of both the Silicon and Gallium Arsenide reference design concepts. The development of (1986-2000) and operational (2000-2029) phases were screened separately because materials demand as a function of time is substantially different for the two phases. The CMAP printout results are presented in Tables 3-10:

\begin{tabular}{r} 
Table No. \\
\hline 3 \\
4 \\
5 \\
6 \\
7 \\
8 \\
9 \\
10
\end{tabular}

$\begin{array}{ll}\text { System/Phase } & \text { Material Type } \\ \text { Silicon/Development } & \text { Bulk } \\ \text { Silicon/Development } & \text { Raw } \\ \text { Silicon/Operational } & \text { Bulk } \\ \text { Silicon/Operational } & \text { Raw } \\ \text { GaAs/Development } & \text { Bulk } \\ \text { GaSa/Development } & \text { Raw } \\ \text { GaSa/Operational } & \text { Bulk } \\ \text { GaSa/Operational } & \text { Raw }\end{array}$


TABLE 3. BULX MATERLAL REQUIREAENTS FOR SOLAR powER SATELLITE dEVELOPMENI (SILICON)

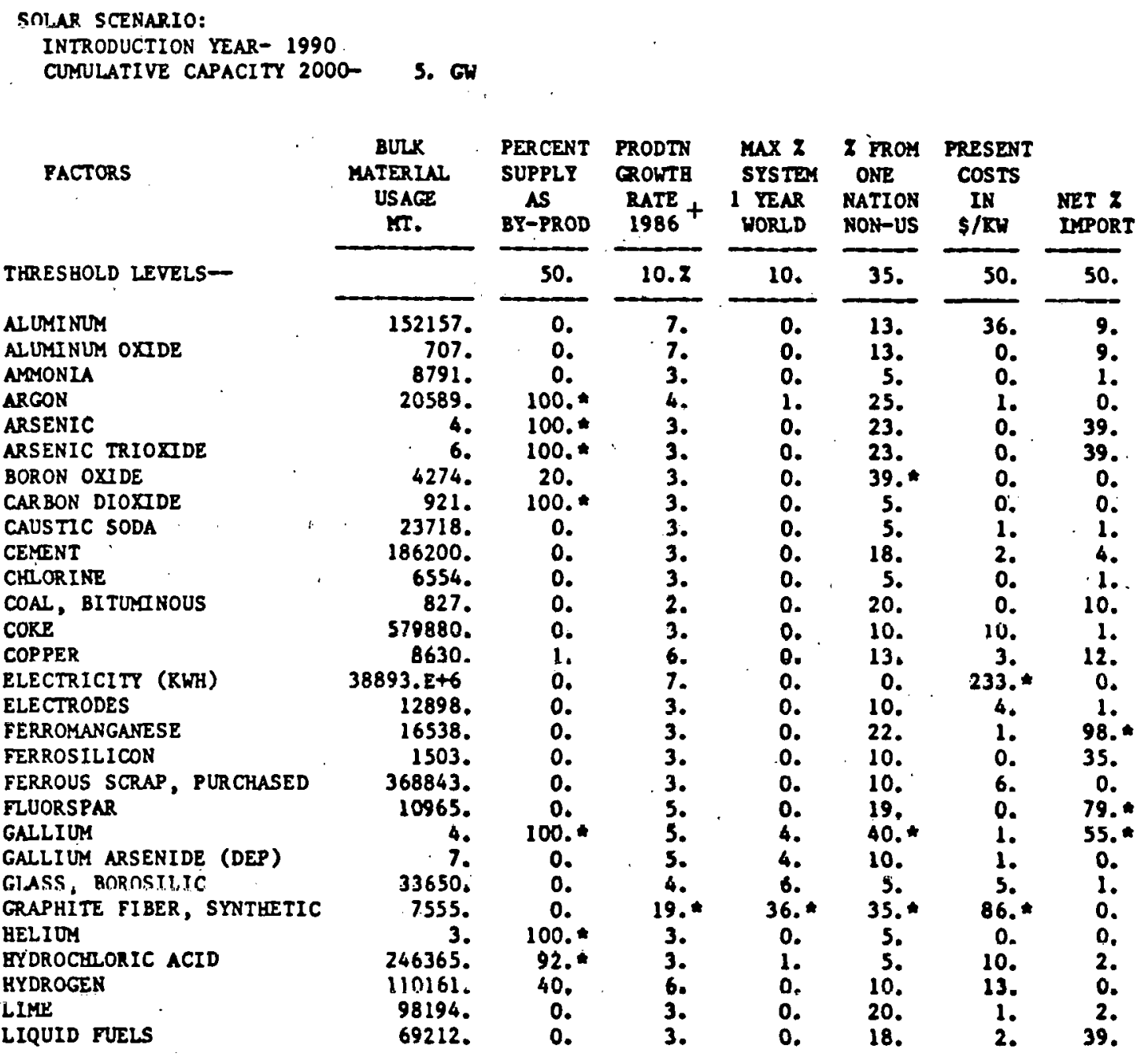

Note: + - Beginning in 1986

* Threshuld exceeded

MT = Metric tons 
TABLE 3. BULR MATERIAL REQUIREAENTS FOR SOLAR POWER SATELLITE DEVELOPNENT (SILICON) (CONTINUED)

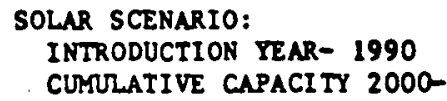

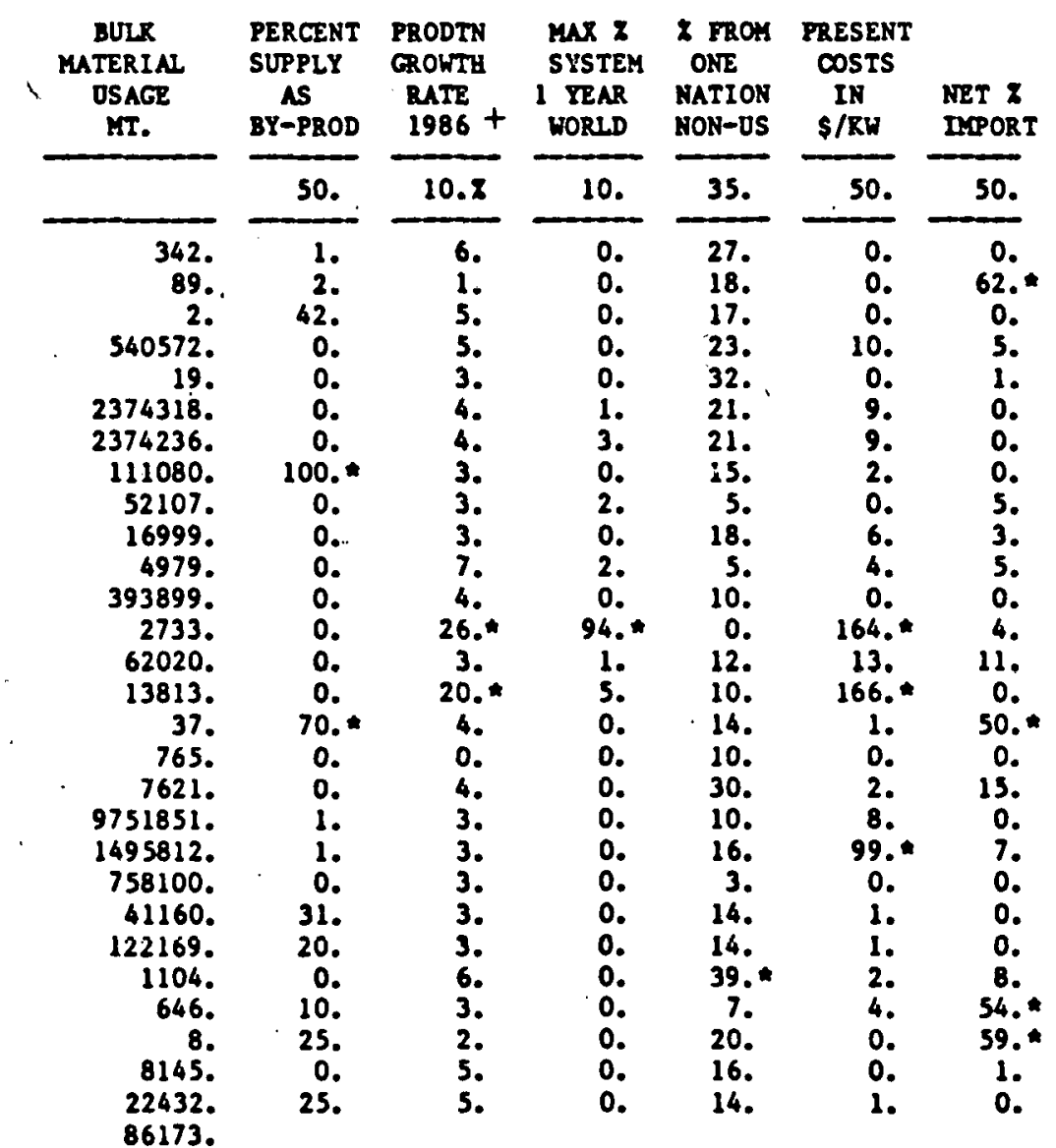

Note: + a Beginning in 1986

* Threshold exceeded MT Metris tnns 
TABLE 4. RAW MATERIAL REQUIREMIENTS FOR SOLAR

pOWER SaTELlite deVELOPMENT (SILICON)

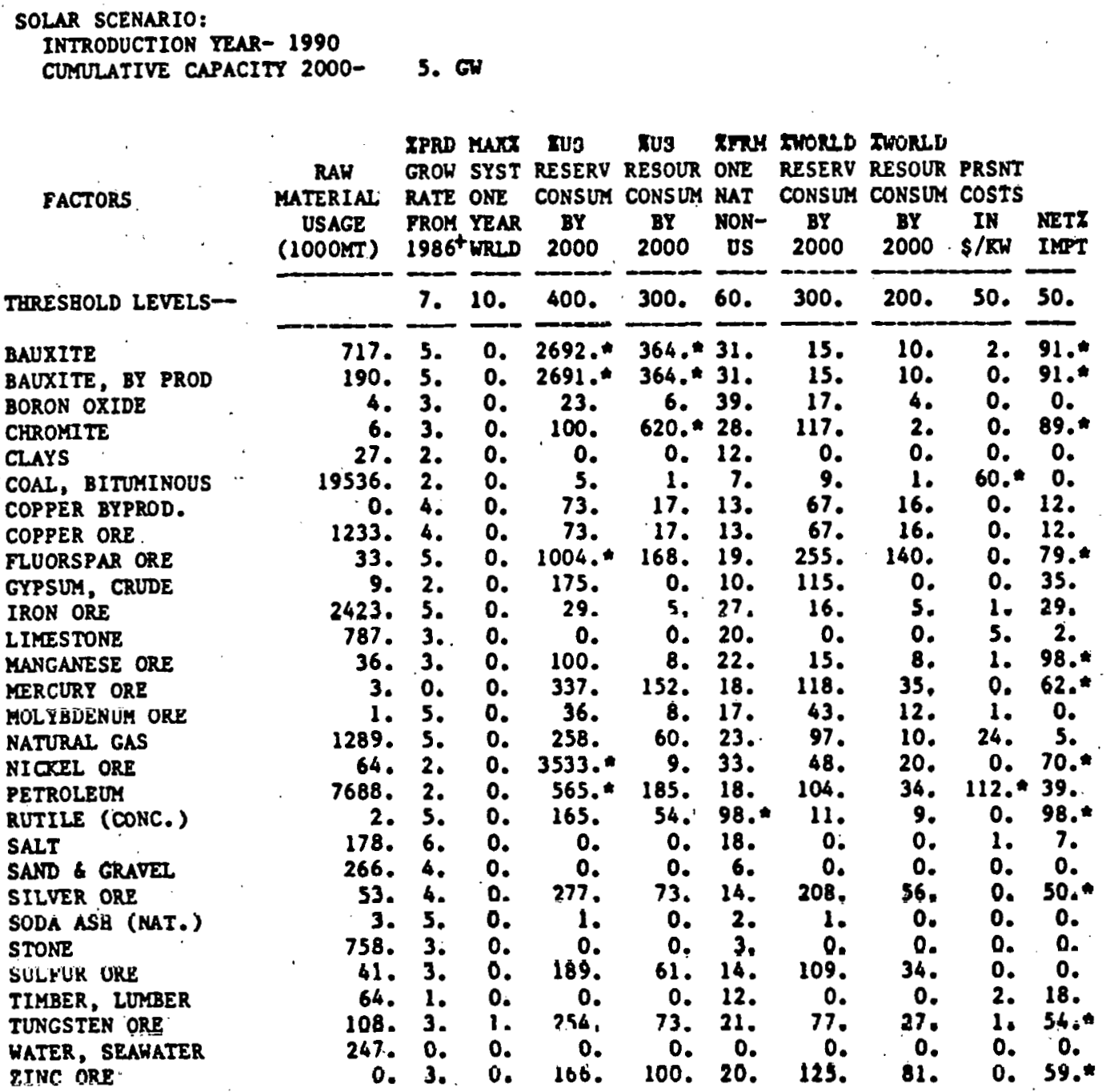

Note: + - Beg1nning in 1986

* - Threshold exceeded

MT - Mecrle Luns 
TABLE 5. BULR MATERIAL REQUIREMENTS FOR SOLAR POWER SATELIITE OPERATIONAL SYSTEM (SIIICON)

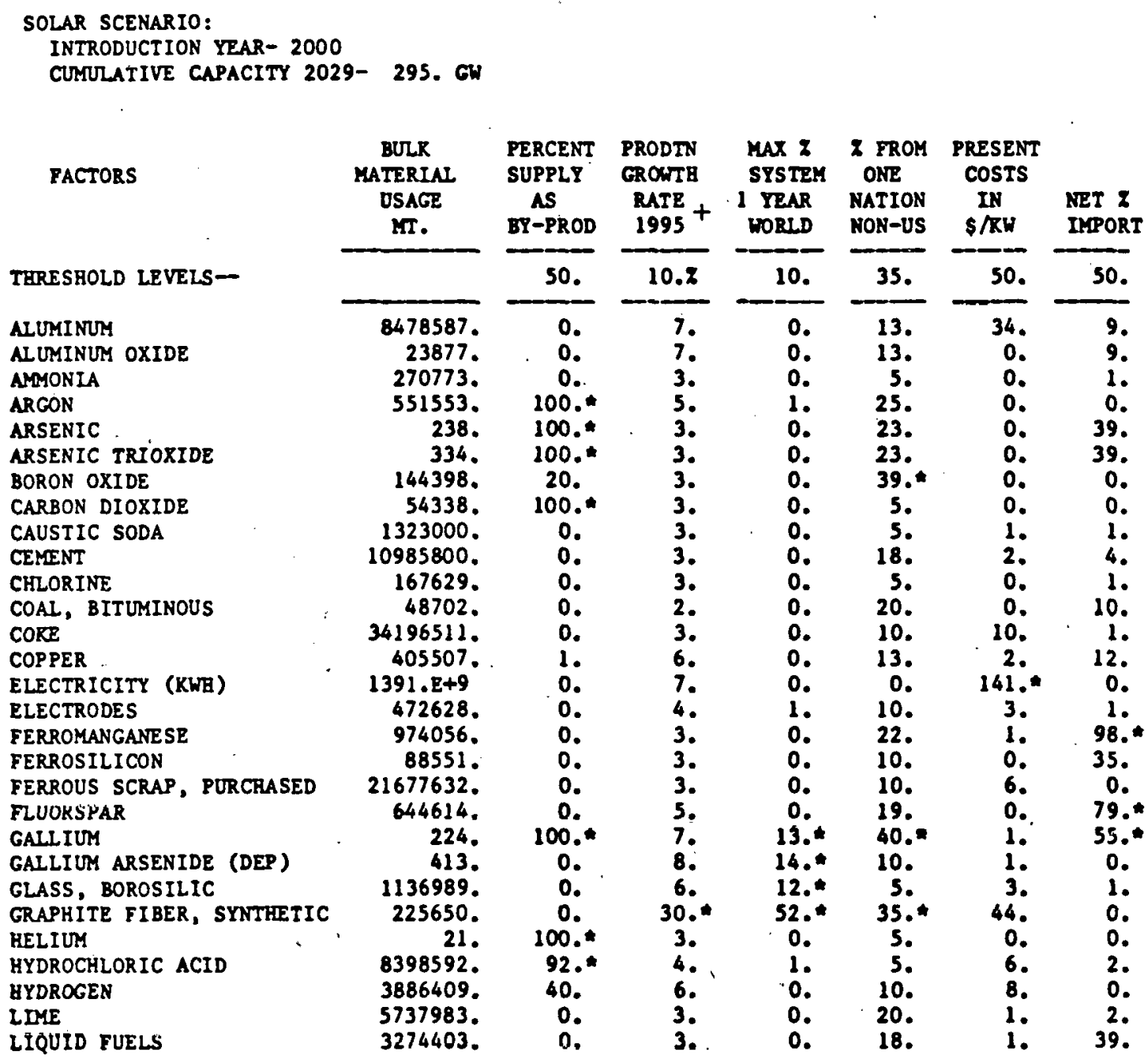

Note: $t=$ Beginning in 1995

* - Threshold exceeded

MT $=$ Metric tons 
TABLE 5. BULK MATERIAL REQUIREMENTS FOR SOLAR POKRR SATELLITE OPERATIONAL SYSTEM (SILICON) (CONT INLED)

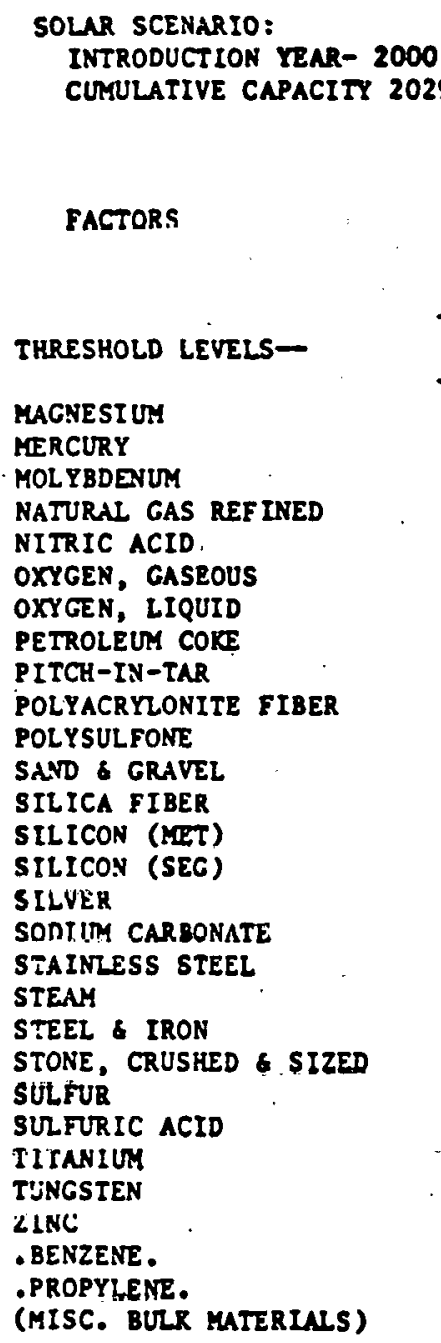

DULR
MTERIAL
USAGE
IT.

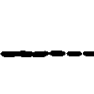

$$
\begin{array}{r}
2268 . \\
5251 . \\
118 . \\
19222171 . \\
143 . \\
86757637 . \\
86754070 . \\
5209156 . \\
2780508 . \\
507712 . \\
150049 . \\
22810692 . \\
18131 . \\
2093584 \\
466277 . \\
2183 . \\
42598 . \\
337657 . \\
399.8+6 \\
88212855 . \\
4727900 . \\
1419127 . \\
4212811 . \\
7316 . \\
38114 . \\
480 . \\
245480 . \\
670353 . \\
4947962 . \\
\end{array}
$$

PERCENT PRODTN SUR PLX . GROWTH As DT-PROD RATE + I YEAR MX 72 FRON PBESENT SYSTEM ONE COSTS YEAR MUTION IN S/KN NET 7 IMPORT

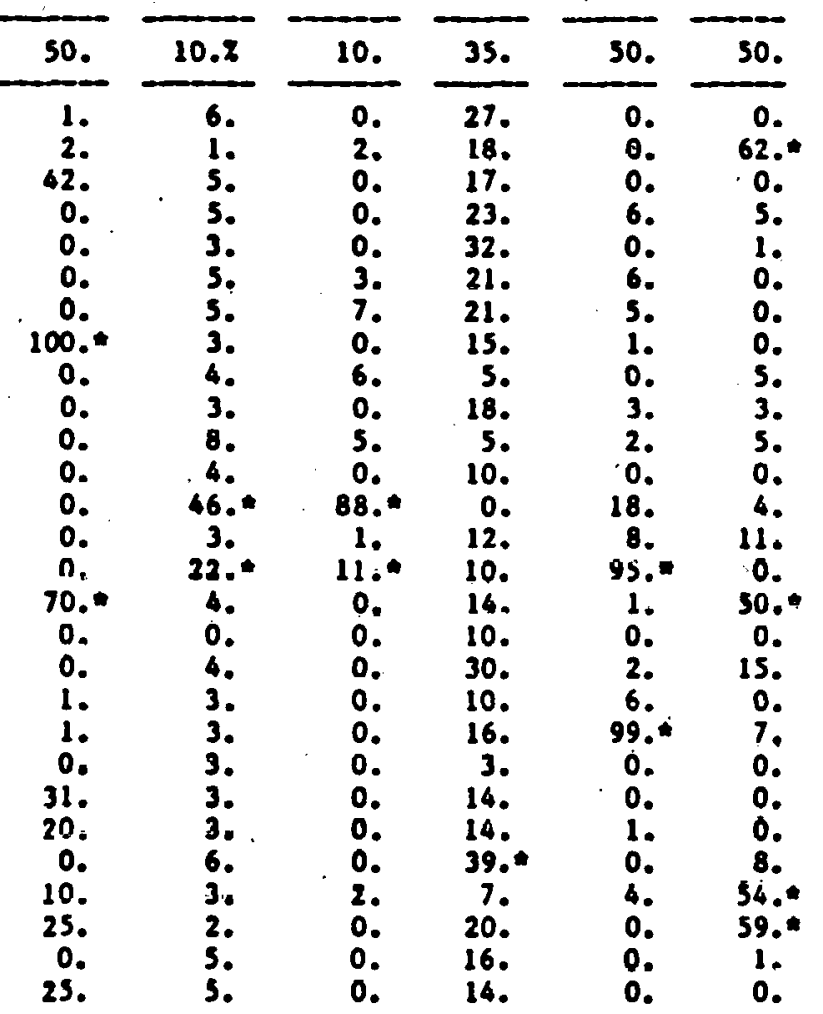

Note: + - Beginning in 1995

* Threshold exceeded MT = Metric tons 
TABLE 6. RAH MATERIAL REQUIREMENTS FOR SOLAR POWER

SATELLITE OPERATIONAL SYSTEỲ (SILICON)

SOLAR SCENARIO:

INIRODUCTION YEAR- 2000

CUMULATIVE CAPACITY 2029- 295. GH

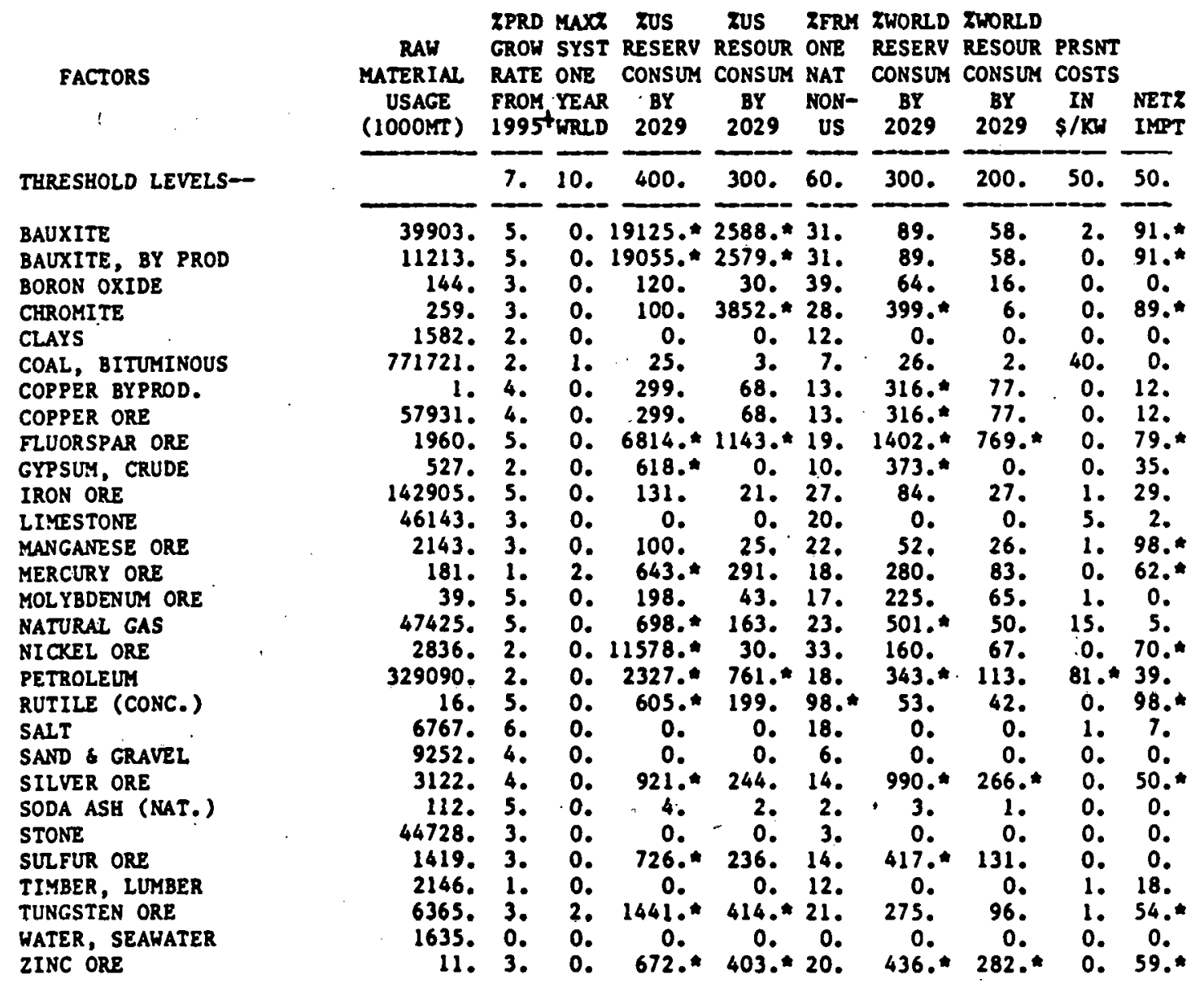

Note: $t=$ Beginning in 1995

* - Threshold exceeded

MT = Metric tons 
TABLE 7. BULX MATERIAL REQUIREMENTS FOR SOLAR FUWKK SATLLLITE DEVELOPHENT (GA/AS)

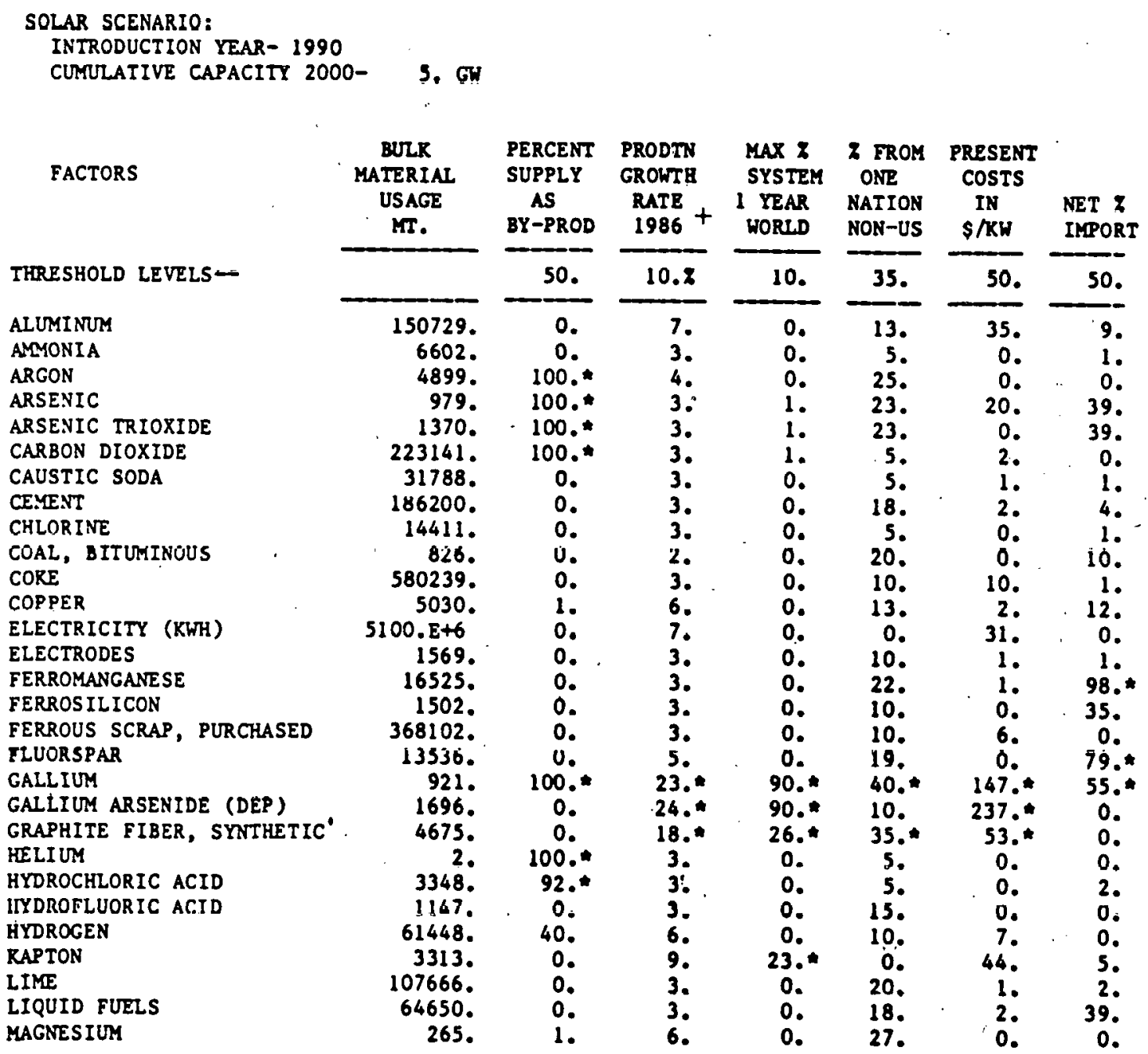

Note: $t=$ Beginning in 1986

* = Threshold exceeded

MT = Metric tons 
IABLE 7. BULR MATERIAL REQUIREMENTS POR SOLAR

POWER SATELLITE DEVELOPMENT (GNAS)

(CONTINUED)

SOLAR SCENARIO:

INTRODUCTION YEAR- 1990

CUMULATIVE CAPACITY 2000-

5. GW

FACTORS

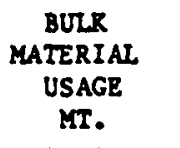

THRESHOLD LEVELS--

MERCURY

NATURAL GAS REFINED

NITRIC ACID

OXYGEN, GASEOUS

OXYGEN, LIQUID

PETROLEUM COKE

PITCH-IN-TAR

POLYACRYLONITE FIBER

POLYSULFONE

SAVD \& GRAVEL

SAPPH IRE

SILICA FIBER

SILVER

SODIUM CARBONATE

STAINLESS STEEL

STEAM

STEEL \& IRON

STONE, CRUSHED \& SIZED

SULFUR

SULFURIC ACID

TEFLON

TITANIUM

TUNGSTEN

ZINC

-BENZENE.

-PROPYLENE.

(MISC, BULR MATERIALS)

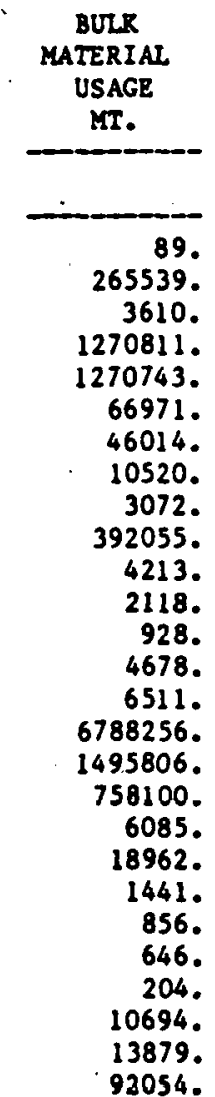

\begin{tabular}{|c|c|c|c|c|c|}
\hline $\begin{array}{c}\text { PERCENT } \\
\text { SUPPLY } \\
\text { AS } \\
\text { BY-PROD }\end{array}$ & $\begin{array}{l}\text { PRODTN } \\
\text { GROWTH } \\
\text { RATE } \\
1986+\end{array}$ & $\begin{array}{l}\text { MAX } 7 \\
\text { SYSIEY } \\
1 \text { YEAR } \\
\text { WORID }\end{array}$ & $\begin{array}{l}7 \text { FROM } \\
\text { ONE } \\
\text { NATION } \\
\text { NON-US }\end{array}$ & $\begin{array}{c}\text { PRESENT } \\
\text { COSIS } \\
\text { IN } \\
\$ / K W\end{array}$ & $\begin{array}{l}\text { NET } 7 \\
\text { IMPORT }\end{array}$ \\
\hline 50. & 10.7 & 10. & 35. & 50. & 50. \\
\hline $\begin{array}{c}2 . \\
0 . \\
0 . \\
0 . \\
0 . \\
100 . \\
0 \vdots \\
0 . \\
0 . \\
0 . \\
0 . \\
0 . \\
70 . \\
0 . \\
0 . \\
1 . \\
1 . \\
0 . \\
31 . \\
20 . \\
0 . \\
0 . \\
10 . \\
25 . \\
0 . \\
25 .\end{array}$ & $\begin{array}{l}1.0 \\
5 . \\
3 . \\
4 . \\
4 . \\
3 . \\
3 . \\
3 . \\
7 . \\
4 . \\
27 . \\
23 . \\
4 . \\
0 . \\
4 . \\
3 . \\
3 . \\
3 . \\
3 . \\
3 . \\
7 . \\
6 . \\
3 . \\
2 . \\
5 . \\
5 .\end{array}$ & $\begin{array}{l}0 . \\
0 . \\
0 . \\
1 . \\
1 . \\
0 . \\
1 . \\
0 . \\
2 . \\
0 . \\
55 . \\
92 . \\
2 . \\
0 . \\
0 . \\
0 . \\
0 . \\
0 . \\
0 . \\
0 . \\
1 . \\
0 . \\
0 . \\
0 . \\
0 . \\
0 .\end{array}$ & $\begin{array}{c}18 . \\
23 . \\
32 . \\
21 . \\
21 . \\
15 . \\
5 . \\
18 . \\
5 . \\
10 . \\
25 . \\
0 . \\
14 . \\
10 . \\
30 . \\
10 . \\
16 . \\
3 . \\
14 . \\
14 . \\
10 . \\
39 . \\
7 . \\
20 . \\
16 . \\
14 .\end{array}$ & $\begin{array}{c}0 . \\
5 . \\
0 . \\
5 . \\
5 . \\
1 . \\
0 . \\
3 . \\
3 . \\
0 . \\
674 . \\
127 . \\
36 . \\
0 . \\
2 . \\
6 . \\
99 . \\
0 . \\
0 . \\
0 . \\
2 . \\
1 . \\
4 . \\
0 . \\
1 . \\
1 .\end{array}$ & $\begin{array}{c}62 . \\
5 . \\
1 . \\
0 . \\
0 . \\
0 . \\
5 . \\
3 . \\
5 . \\
0 . \\
0 . \\
4 . \\
50 . \\
0 . \\
15 . \\
0 . \\
7 . \\
0 . \\
0 . \\
0 . \\
8 . \\
8 . \\
54 . \\
59 . \\
1 . \\
0 .\end{array}$ \\
\hline
\end{tabular}

Note: + a Beglnning in 1986

* Threshold exceeded

MT = Metric tons 
TABLE 8. RAH MATERIAL KEQUIREYENTS FOR SOLAR POVER SATELLITE DEVELOPMENT (GA/AS)

SOLAR SCENARIO: INTRODUCTION YEAR- 1990 CURURATIVE CAPACITY 2000

5. CW

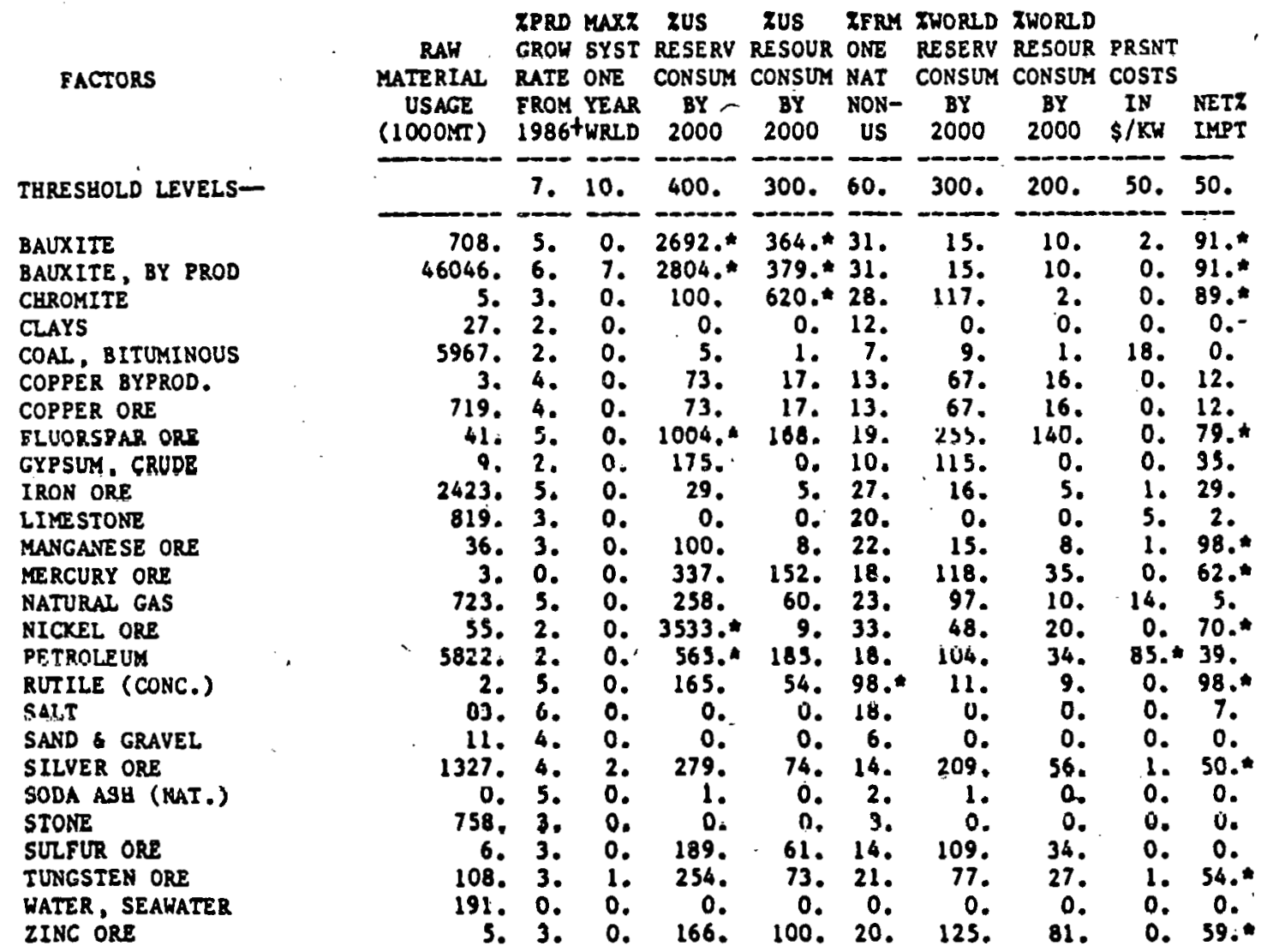

Note: + - Beg1nning 1 in 1986

* - Threshold exceeded

MT - Metric tons 
IABLE 9. BULK MATERIAL REQUIRETENTS FOR SOLAR POWER SATELLITE OPERATIONAL SYSTEM (GA/AS)

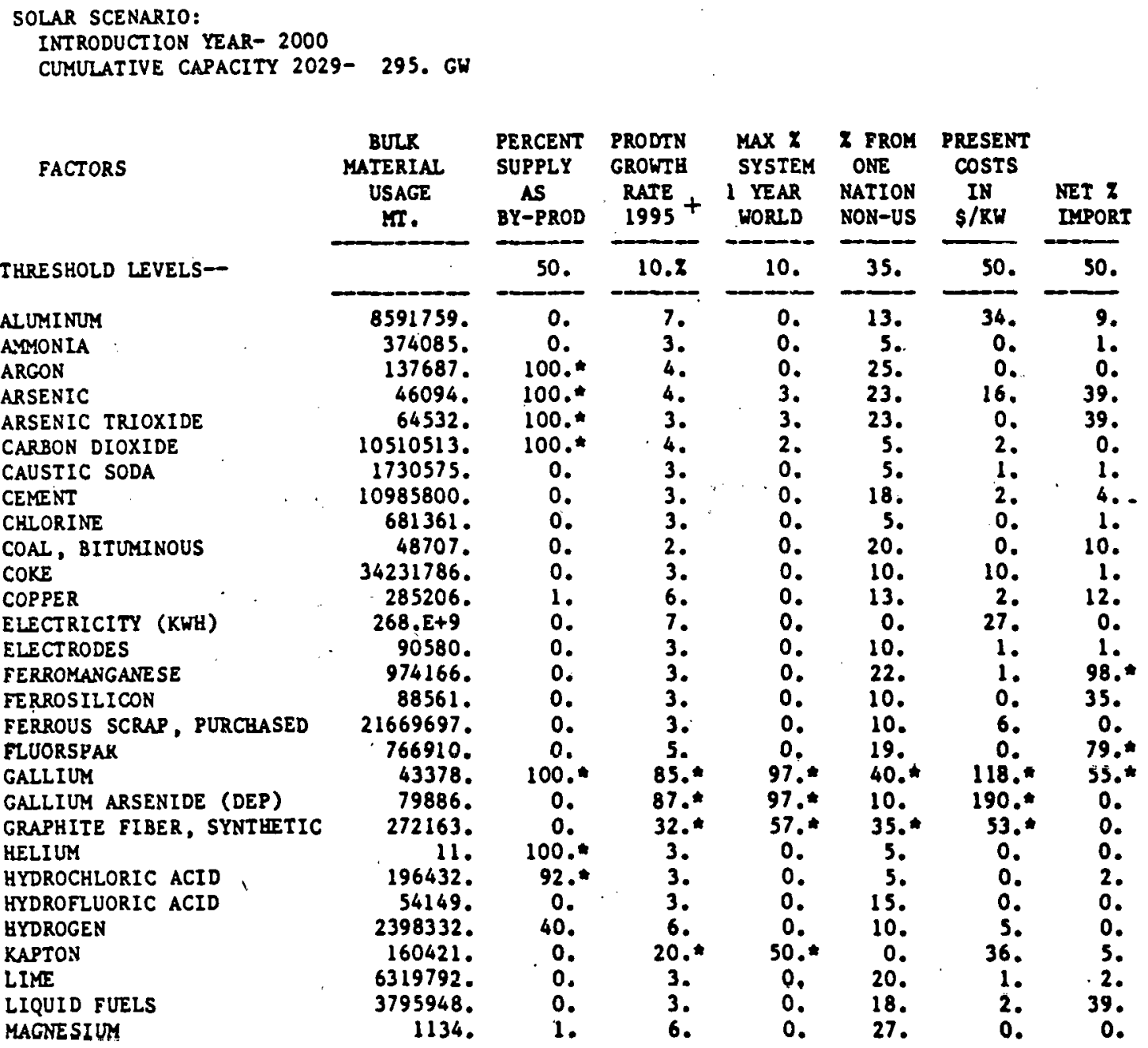

Note: $t=$ Beginn1ng in 1995

* = Threshold exceeded

MT = Metric tons 
IABLE 9. BULK MATERIAL REQUIREMENTS FOR SOLAR POWER SATELLITE OPERATIONAL SYETEM (OA/AS)

(CONTLNUED)

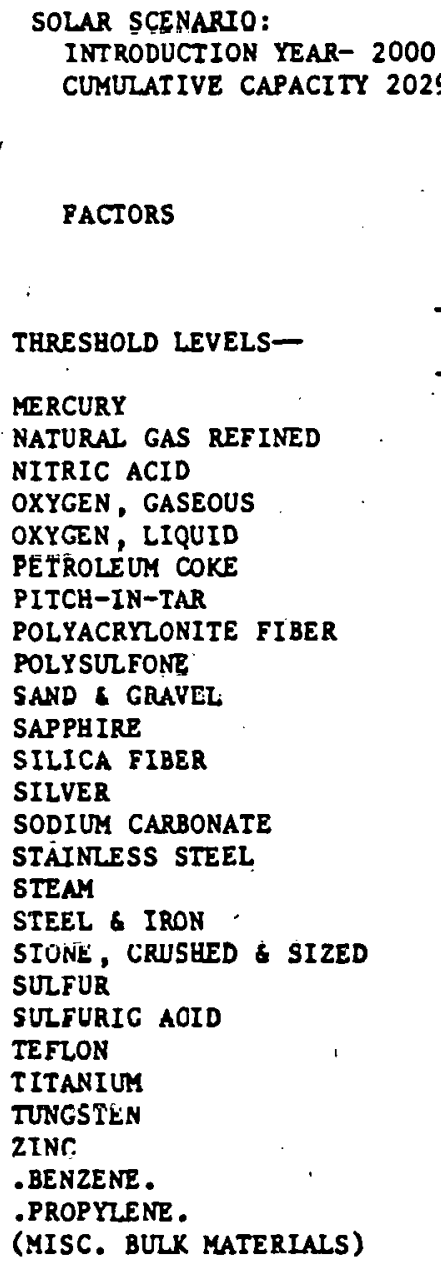

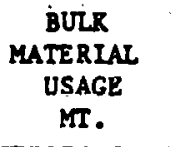

$$
\begin{aligned}
& \text { PERCENT } \\
& \text { SUPPLY } \\
& \text { AS } \\
& \text { BY-PROD }
\end{aligned}
$$
PRODTN
GROWTH
RATE
1995 $\operatorname{MAX} 7$ SYSTEM ONE
1 YEAR NATION WORLD NON-US

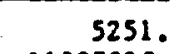
11207935. 174060 . 55850565 . 55847290 . 3792213. 2623435 . 612367 . 181248 . 22783760 . 199184. 9153. 54752 . 271913. 312995. $315 . E+6$ 88247973. 44727900 . 327322 . 1014141 . 68027. 3658 . 38114 . 12045. 571002 . 808610 . 5025022 .

\begin{tabular}{rrr}
\hline 50. & 10.8 \\
\hline 2. & 1. \\
0. & 5. \\
0. & 3. \\
0. & 4. \\
0. & 3. \\
100. & 3. \\
0. & 4. \\
0. & 3. \\
0. & 8. \\
0. & 4. \\
0. & 54. \\
0. & 33. \\
70. & 5. \\
0. & 0. \\
0. & 4. \\
1. & 3. \\
1. & 3. \\
0. & 3. \\
31. & 3. \\
20. & 3. \\
0. & 8. \\
0. & 6. \\
10. & 3. \\
25. & 2. \\
0. & 5. \\
25. & 5.
\end{tabular}

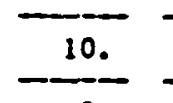

35.

0.23.

0.32 .

2. 21

4. 21.

0.15

6.5.

1. 18.

0.10.

78. 25.

$78 . *$

6.

0.

14.

0.10.

0.30 .

0.10.

0.16.

0.3.

0.14.

0. 14.

3. 10.

0 . 39.*

2.7 .

o. 20 .

0.16.

o. 14.
PRESENT costs

IN NET $X$ $\$ / K W$ IMPORT

$\frac{50 .}{0 .}-\frac{50 .}{62 .}$

4. 5.

$0 . \quad 1$.

4. 0.

1. 0.

0.5 .

3.3.

3. 5

540. 0.

9.4

36. 50.

0.0 .

1. 15.

99. 7.

0.0 .

0.0 .

$0 . \quad 0$.

2. 8 ,

0.8.

4. 34.

$0.59 . *$

0. 1. 
IABLE 10. RAH MATERIAL REQUIREMENTS FOR SOLAR POWER SATELLITE OPERATIONAL SYSTEM (GNAS)

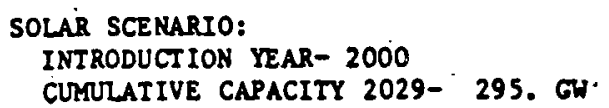

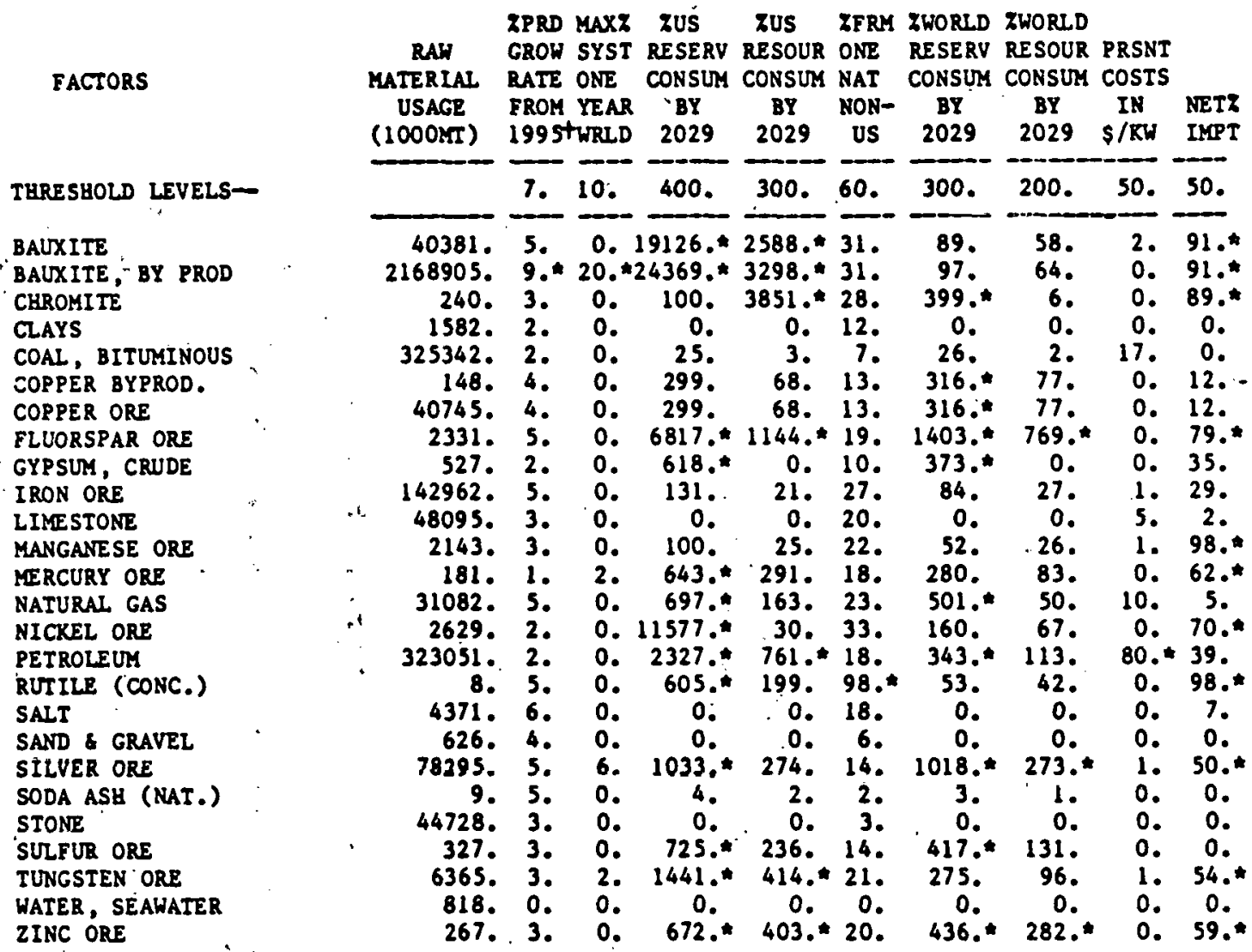

Wiote: + - Beginning in 1995

* - Threshold exceeded

MT = Metric tons 
V - ANALYSIS OF RESULTS

By-Product/Co-Product Problems

Our screening criterion is a threshold value of 50 percent for any material whose production is reliant on being a co-product or by-product of another material. Tablc 11 indicates the bulk materials that are "flagged"as meeting this criterion.

By-Products/Co-Products of No Concern

Those materials that are flagged but present no real problem Include

Argon is a co-product of production of oxygen by air liquefication/separation. No supply problems are anticipated since oxygen demand will remain high. The SPS itself would be a high oxygen demander.

Carbon Dioxide is rarely produced as a primary material. It is a by-product of many industrial chemical processes. Its potential for recovery is almost unlimited.

Helium is recovered as a coproduct from certain helium rich natural gas deposits through low temperature liquefaction. If necessary it could also be recovered as a co-product of oxygen production by air liquefaction -- but at' much higher cost. At the level of SPS demand for helium, we would anticipate no problems.

Hydrochloric Acid is a by-product of several chemical processes. In general, it is a "glut" on the market. No problems are anticipated. 
TABLE 11. PERCENT SUPPLIED AS BY-PRODUCT/COPRODUCT THRESHOLD VALUE 50 PERCENT

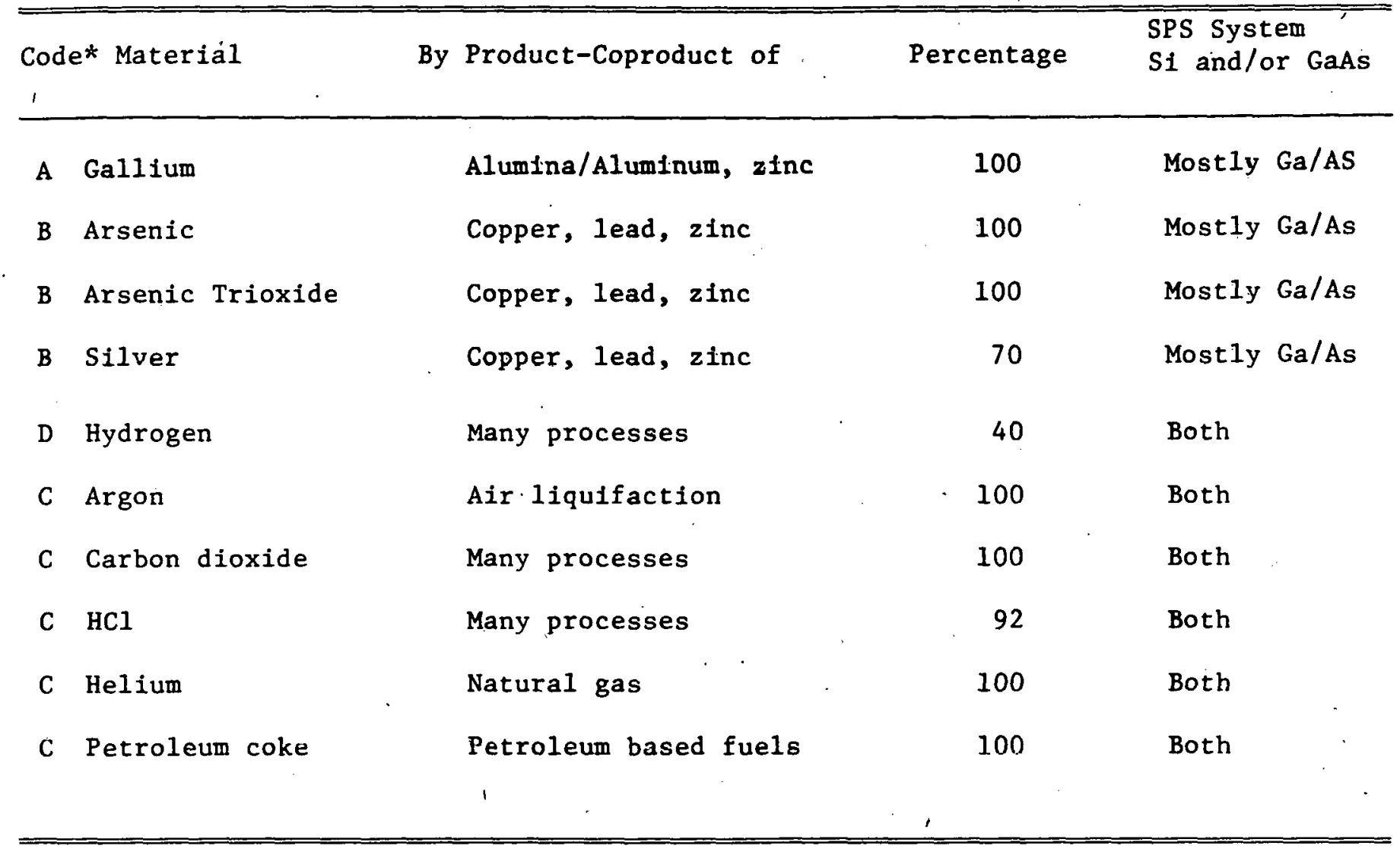

* Code Interpretation

A Serious concern

B Possible concern

C No concern

v Not flagged, but of concern 
Petroleum Coke is a by-product of the refining of petroleum of liquid fuels. Avallability in the amounts required for SPS presents no problem. Possible future inadequacy of petroleum-based fuels might present a far larger problem than petroleum coke per se.

\section{By-Products/Co-Products of Possible Concern}

Silver is most of ten a by-product of the production of copper, lead, and zinc, and silver prices ran nften bo a dociding factor in the exploitation of some of those ore bodies.

Silver recovery directly from silver ores per se represents perhaps only 30 percent of total silver production. Trends toward on-site leaching of copper ores (rather than conventional milling) could reduce by-product silver recovery and therefore silver production does represent a possible problem. However, silver production is very responsive to price and recent higher silver market prices will go a long way toward increasing primary silver production as well as increasing secondary recovery of silver.

Arsenic and Arsenic Trioxide are included as materlals of possible concern because of the special circumstances surrounding domestic capacity. Both materials are in plentiful supply worldwide, however, there is only one U. S. supplier, and that operation has had severe environmental and safety problems. It currently is operating under court-ordered 5-year variance from Washingtion State air pollution standards. Arsenic and several of its compounds are also lister in. OSHA's Number I carrinngen group.

In addition to the above, the future market outlook for arsenic is not strong. A future business decision to close U.S. sme1ter operations would not come as a surprise.

It should also be noted that U.S. production of very high purfty arsenic (99.999) is quite limited. Current U.S. production by a single supplier is only about 5 metric tons per year. 
By-Products/Co-Products of Serious Concern

Gallium is most commonly recovered as a by-product of the production of alumina from bauxite. The alumina is then processed into aluminum. Average gallium content in bauxite 1 s about 0.005 percent. Current processing techniques recover about 40 percent of the gallium. Unfortunately, few bauxite processors currently recover gallium. The $\mathrm{Ga} / \mathrm{As}$ version of SPS would require at least $1470 \mathrm{MT}$ of gallium per year which would require processing of 73,500,000 MT of bauxite.* World demand for bauxite in 2000 is expected to be about $271,000,000$ MT. Hence, adequate quantities of bauxite will be processed worldwide to recover the needed gallium, if sufficient market and price incentives are present.

The major question would then become "where will the bauxite be processed to alumina?" Over one-third of U.S. alumina consumption is currently imported and that proportion will almost certainly rise over the coming decades.

By-Product/Co-Product - Not "Flagged" But of Possible Concern

Hydrogen is usually either a process by-product, used captively, or it is manufactured captively for particular chemical processes. Probably over 98 percent of hydrogen produced is so consumed. Hydrogen is readily manufactured by several processes, most commonly from natural gas and steam as feedstock. It is also of ten (perhaps 40 percent of ' production) a byproduct recovered for its chemical values in downstream production. Petroleum refining is a primary example.

Liquid hydrogen production for sale probably reprsents no more than about $1 / 2$ percent of total U.S. hydrogen production--or perhaps

*New technology could possibly recover 80 percent of by-product gallium which would reduce bauxite requirement by 50 percent. 
about 40,000 metric tons in 1976. Hence, total U.S. hydrogen production is not a rellable guide for SPS requirements. SPS requirements of 80,000 to $130,000 \mathrm{MT} /$ year would represent a very large share of expected U.S. production of non-captive liquid hydrogen in year 2000 of about 185,000 metric tons.

\section{Production Capacity/System Market Demand Problems}

In the assessment of SPS, these two factors tend to coexist with one another. This results from some of the specific "exotic" or new material demands of the present SPS reference design. These materials are in limited commercial supply at present, and SPS would demand substantial shares of them relative to other expected market demands.

The worst case is represented by the system "introduction" year 2000 when two 5-GW systems would be built. We assume capacity build-up would begin in 1995 .

Following is a tabulation (Table 12) of those materials presenting the most serious production capacity/market impact problems in year 2000.

The following paragraphs further elaborate on the tabular data presented.

Gallium presents the most severe problem. As discussed earlier under by-product problems, there is probably enough gallium in the amount of bauxite expected to be processed in year 2000 to reaconably accommodate SPS demand. Hnwever; the rate-of-growlh nceded in pruductive by-product recovery processes would be huge. In the current economics of alumina/aluminum production, by-product gallium recovery is not a significant contributor to economic viability even at today's very high gallium prices. The use of gallium, particularly in gallium arsenide electronic applications (non-solar) is expected to grow perhaps 6 percent to 7 percent in future years. However, an SPS demand of 1470 $\mathrm{MT} / \mathrm{yr}$ would completely dominate the market ( 97 percent of demand in year 
$\because$ TABLE 12. CAPACITY/MARKET FACTORS OF CONCERN

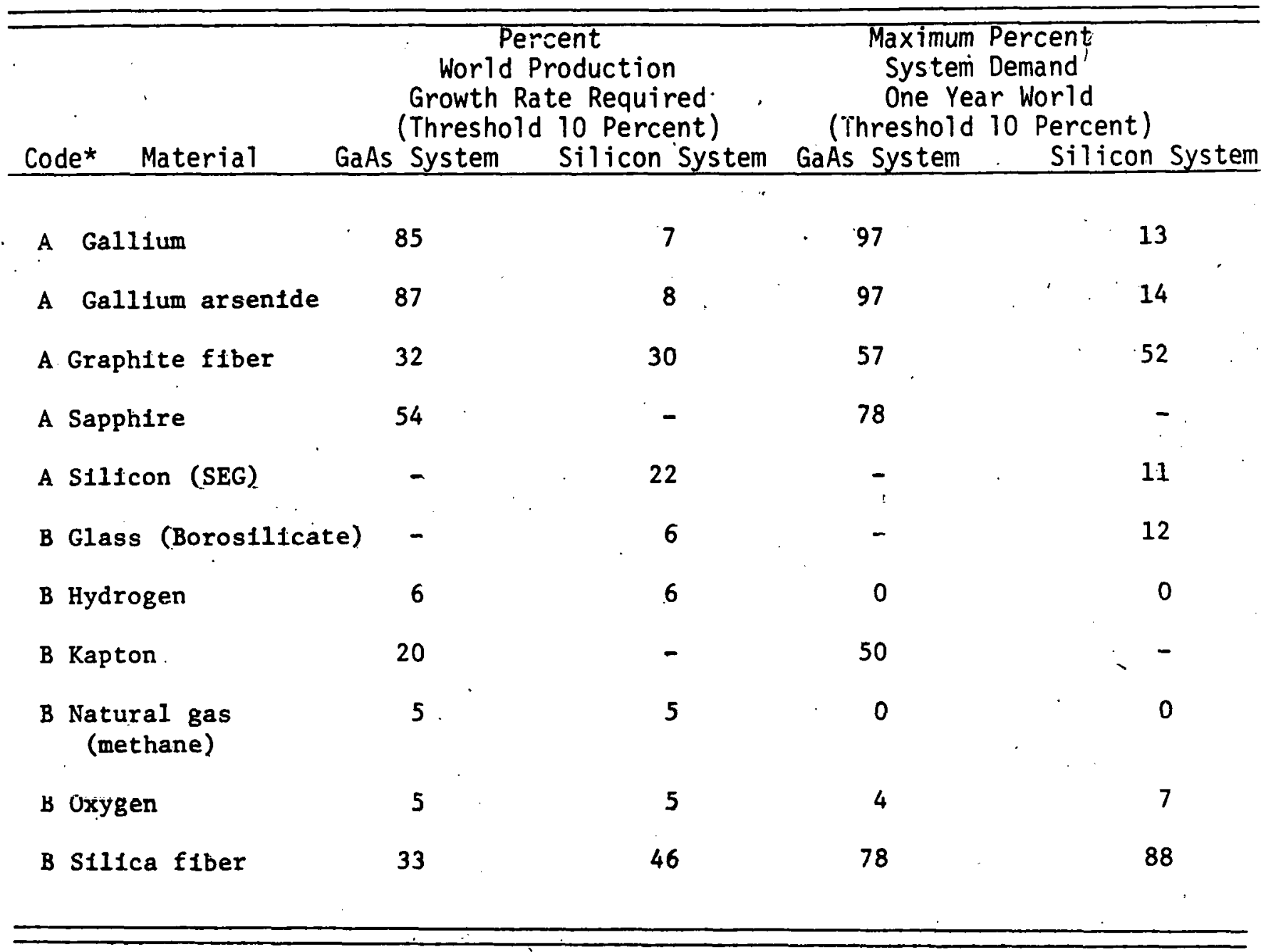

* Cude Interpretation

A Serious concern'

B Possible concern 
2000). It would seem clear then, that only if that market were completely assured, would the necessary gallium world-wide production capacity be forthcoming.

These observations are made in the absence of consideration of the possible use of gallium arsentde as an economic terrestially-based solar cell. If this potential were to be realized within the next 10 to 15 years, then growth of gallium production for sPS might be more readily accommodated. This eventuality, however, would mean even more demand for gallium and perhaps start to cutend recuvery operations toward marginal gallium concentrations and consequent higher prices.

Gallium Arsenide. Crystal growth of GaAs from melt is a crude art. Epitaxial growth is considerably more advanced, but st1ll a very slow process. Less is known about epitaxial growth of GaAs on sapphire substrates.

Consequently, the timing of the development of true production processes for these materials in the quantities needed by SPS (about $2700 \mathrm{Mt} / \mathrm{yr}$ ) is very speculative. We can assume that the development process may take at least 5 to 15 ycars. Therefore, starting in 1985 at best (or more 1lkely 1995), large incremencs of capacity would need to be built for a market that would be dominated by SPS. This could only be accomplished under a system of assured markets.

Sapphire. Most synthetic sapphire is produced today as slices from single crystal boules, but ribbon growing is rapidly developing. The production level in 1976 was probably about 10 metric tons, and today perhaps about 25 to $30 \mathrm{MT}$. Electroulc applications are the major market drivers. At an estimated growth rate of about 20 percent/year, about $800 \mathrm{MT}$ would be produced in year 2000 .

Therefore, similar to the case of Gallium/gallium arsenide, very large increments of capacity would need to be added for a market dominated by SPS.

The U.S. is currently an exporter of synthetic sapphire, but the raw materlal ( $99.999^{\circ}$ percent pure ground crystal) is almost all 
imported from Switzerland and France. Domestic production of the raw material was discontinued a few years ago, but could possibly be reestablished if the market continues its growth.

Silicon (SEG). U.S. consumption of semiconductor grade silicon (SEG) in 1976 was about $700 \mathrm{MT}$. Today, consumption might be about 1000 to $1200 \mathrm{MT}$, and applications are very largely electronic in nature. Technology for production of silicon crystal by ribbon growing techniques is rapidly advancing. Despite a projected annual growth rate of 20 percent/year, substantial additional capacity for silicon SEG would be required for SPS. If the projected growth rate for silicon SEG is realized, the capacity problem might not be nearly so severe as for gallium and sapphire. However, SPS would still consume 11 percent of world production--an uncomfortable market position.

Production capacity for metallurgical grade silicon (Silicon MG) as a raw material should present no problem.

Graphite Fiber. World consumption of graphite fiber in 1976 was about $215 \mathrm{MT}$. Based on potential substantial use by the automobile industry, it is projected to grow by about 15 percent/year to about $6,160 \mathrm{MT}$ by year 2000. SPS demands in 2000 would require additional capacity growth of over 30 percent/year beginning in 1995. SPS would also be very market dominant, requiring over 50 percent of world capacity.

It is also likely that SPS would require very high modulus graphite fiber. High modulus fiber is very costly, representing a tiny fraction of today's production and, therefore, graphite fiber capacity to be added for SPS consumption would probably be very specialized. The market would need to be completely assured to bring forth this higher level of very special fiber.

Raw material complications might be present if rayon were designated as the graphite fiber precursor. The rayon fiber currently used to manufacture high modulus graphice flber is also "spccial". 
Current production capacity for that rayon fiber is less than half the annual requirements for SPS. Given present rayon market trends, current capacity for that special precursor fiber is very unlikely to be increased without an assured market.

If polyacrylonitrile (PAN) fiber were used as the graphite fiber precursor, no raw material problems would be anticipated.

Borosilicate Glass. This glass with special thermal properties is exemplified by Pyrex. Assuming normal market growth, (about 3 percent to 4 percent per year) world production by year 2000 might be near $70,000 \mathrm{MT}$. To produce SPS requirements $(38,542 \mathrm{MT}$ in 2000) would require a 6 percent annual growth from year 1995, and SPS would consume about 12 percent of world requirements. From a capacity growth and market domination point of view this situation is marginal.

Problems of producing and assembling the glass in the required 50 and 75 micron thicknesses also present a very substantial set of technical complexities. Costs per unit of weight would be far in excess of the values assigned to the bulk material per se.

\section{Natural Gas (Methane)/Hydrogen/Oxygen}

These are basically the transportation fuels of SPS. Each presents a somewhat different problem.

Methane in the CMAP data base is currently treated as natural gas. The methane $\left(\mathrm{CH}_{4}\right)$ component of natural gas varies widely. The critical question of supply (beyond the general concern for natural gas supply) becomes one of purity. Some domestic deposits (Alaska).produce a Bulfur free methane purity of 99.5 percent. Other U.S. and world deposits may be as low as 70-80 percent methane.

A requirement of $651,599 \mathrm{MT}$ of liquid methane annually for SPS space vehicle operations is quite small compared to an expected world production of over 3 billion metric tons of natural gas in year 2000 . However, the general outlook for natural gas (national priorities and price) is cause for speculation. Also, liquid methane is not a conventional or common commodity of commerce. 
Through distillation separations, liquefied natural gas (LNG) from many U.S. and world sources could be used as a source of liquid methane of nearly any required purity. Methane could also be produced from coal or blomass. These latter two options would require substantial capital investments.

Hydrogen. Desplte very large world production of hydrogen, liquid hydrogen is not a common market commodity. NASA has been among the largest consumers. As discussed under "by-product problems", SPS could easily consume 50 percent of expected 11quid hydrogen production in year 2000. This presents obvious problems of capacity and market share.

Oxygen. About 30 percent of total oxygen production is presently liquified, hence, the liquid product is not uncommon. SPS vehicle requirements of over 2.7 million MT annually would however represent nearly 7 percent of liquid oxygen world production in year 2000. It is therefore possible that dedicated liquification facilities might need to be considered.

Kapton. The raw material base for Kapton (benzene, chlorine, durene, etc.) presents no unique problems. However, Kapton is a proprietary product whose production capacity would need to be increased substantially. Beginning in 1995, the production base would need to be increased 20 percent/year and in 2000, SPS would consume 50 percent of total capacity.

This proprletary product situation is almost unique (Teflon is the other) in the SPS materials assessment. The material presents a capacity and market share problem with the current added dimensions of single source. It is not necessarily a serlous problem, but it is "different".

Sillca F1ber. The heat shielding insulation (ceramics) of reusable space vehicles is assumed to be simflar to the insulation on 
the current shuttle. A large proportion of those insulating tiles are based on a special silica flber. One firm produces the silica fiber; another produces the tiles. Tile production is quite sophisticated. The annual quantities required by SPS are not large, but production capacity would have to grow 46 percent/year beginning in 1995 and SPS would completely dominate the market. Again, a typical capacity/market domination situation would prevall.

\section{Resource Depletion Problem}

The sereening progrem flags those raw materials where total world consumption of those resources by year 2029 (including SPS) is expected to exceed 200 percent of the currently identified resource base. Resources for nearly all materials are continually being identified worldwide and the history of the identified world resource base indicates that a 200 percent increase in the identified world resource base over the next 50 years is a reasonably conservative assumption.

Those raw materials demanded by SPS that indicate resource consumption, including SPS, of over 200 percent by 2029 are shown in Table 13. The 1978 identified resource base is shown as well as the annual requirements of SPS related to that base.

\section{TABLE 13. WORLD RESOURCES - PERCENT CONSUMED BY 2029 AND SPS DEMAND}

\begin{tabular}{|c|c|c|c|c|c|}
\hline & \multirow{2}{*}{\multicolumn{2}{|c|}{$\begin{array}{l}\text { Percent } \\
\text { World } \\
\text { Resource } \\
\text { Consumption } \\
\text { Year } 2029\end{array}$}} & \multirow{2}{*}{$\begin{array}{c}\text { Ty78 } \\
\text { Ore } \\
\text { Resource } \\
\text { Base } \\
1000^{\circ \mathrm{MT}} \\
\end{array}$} & \multicolumn{2}{|c|}{$\begin{array}{c}\text { Total } \\
\text { SPS } 300 \mathrm{GW} \\
\text { Consumption by } \\
\text { Year } 2029\end{array}$} \\
\hline & & & & $\begin{array}{c}\text { Si } \\
1000 \mathrm{MT}\end{array}$ & $\begin{array}{c}\text { G.aAs } \\
1000 \text { MT }\end{array}$ \\
\hline Fluorspar Ore & 769 & 769 & 456,000 & 1993 & 2373 \\
\hline Silver ore & 266 & 273 & $7,050,000$ & 3175 & 79,622 \\
\hline Zinc ore & 282 & 282 & $53,600,000$ & 11 & 272 \\
\hline
\end{tabular}


The consumption of the fluorspar ore and zinc ore resource base by SPS represents only a tiny fraction of world demand for those ores and make no measureable impact on the rate of resource depletion. There are also reasonably viable substitutes for each material, hence these should not be viewed as critical materials.

The gallium arsenide reference design however would consume something over 1 percent of the world's currently identified silver ore resources and increase the depletion rate from 266 percent to 273 percent. While not terribly significant from a resource depletion point-of-view, we would expect a continued rise in silver prices as more marginal resources are exploited.

\section{Import Dependency Problems}

The criticality of import dependency relative to SPS is a function of the current U.S. levels of import, the future U.S. material demand outlook, and SPS demand as a proportion of that total U.S. demand. In the latter case we should probably view SPS import demand as "critical" only if it might significantly exacerbate an already existing high level of domestic dependency on imports for many other uses.

While the import dependency threshold ( 50 percent). is measured against todays U.S. import levels, we can probably safely assume that some bulk materials and nearly all raw material dependencies will become even greater by year 2000 .

Tables 14 and 15 present the import dependency factor for both reference systems. They indicate the SPS annual requirements in metric tons for bulk materials, and $1000 \mathrm{MT}$ for raw materials. If those numbers represent a high proportion of year 2000 U.S. consumption for specific materials, this would indicate situations where SPS could significantly increase dependency.

In general, the GaAs reference design option presents the more severe import dependency problems. These relate to significantly higher use of gallium, arsenic, and silver. 
TABLE 14. RAW MATERIAL IMPORT DEPENDENCY FACTORS

PERCENT U.S. IMPORTS 1976.

(Threshhold Value - 50 Percent)

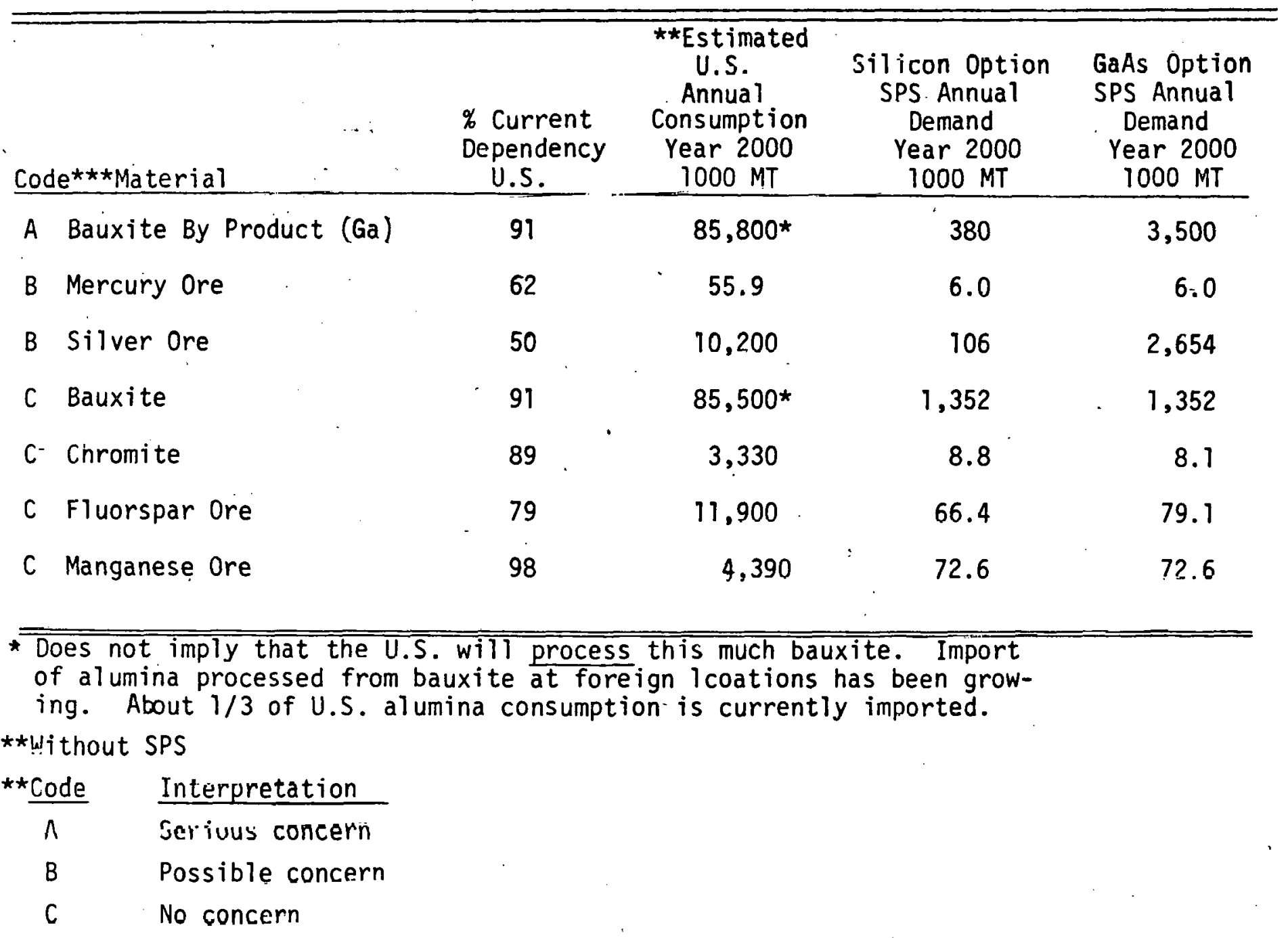


TABLE 15. BULK MATERIAL IMPORT DEPENDENCY FACTORS OF CONCERN.

PERCENT U.S. IMPORTS 1976

(Threshhold Value 50 Percent)

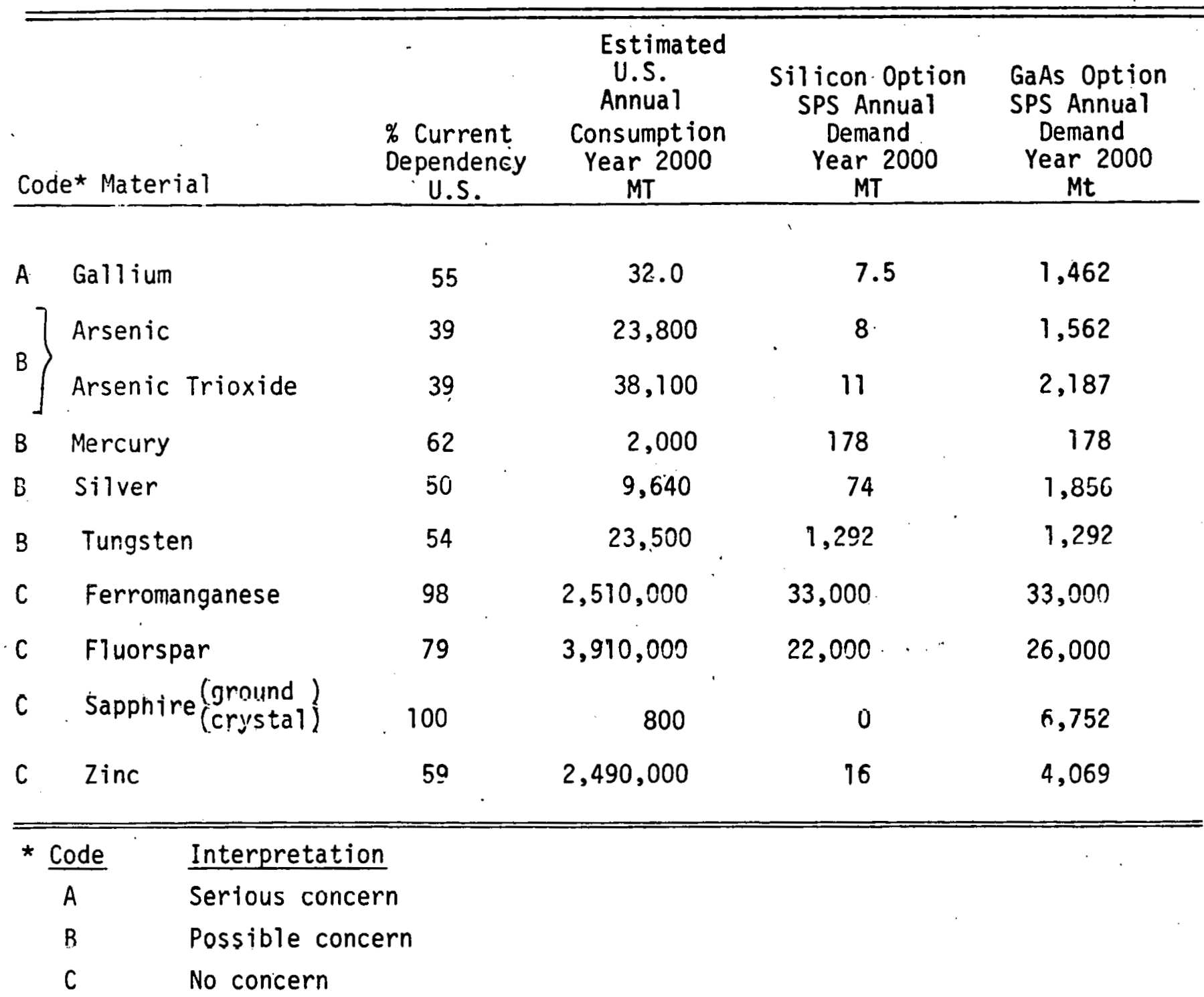


Both options would require a high proportion ( $9 \%$ ) of expected U.S. mercury consumption in year 2000. Both options would also represent $5 \%$ of U.S. tungsten consumption.

\section{Material Cost Problems}

The CMAP screening threshold for material cost is set at $\$ 50.00$ per KW of lustalled capacity. This would represent about 5 percent of the total cost for an "average" $\$ 1,000.00$ per $\mathrm{KW}$ conventional power generatịng system.

It should be borne in mind that the values produced by the CMAP program are the current values of the unfabricated bulk materials. The present program also assumes no waste, and therefore the values represent a floor value for materials.

The costs are additive only if one selects the final materials specified for the system. For example, materials cost for GFRTP would be the cost of graphite fiber plus the cost of polysulfone. Conversely, the cost of aluminum would already incorporate the cost of caustic soda used in its manufacture.

The bulk materials that exceed the threshold value are shown in Table 16.

Electricity. Consumption of electricity by the silicon option is nearly 5 times that of the gallium arsenide option.* This is due to the very large energy requirements to produce silicon (SEG). Ratrellig's very preliminary estimate for energy consumption to produce silicon SEG is about 2,300,000 Kwh per metric ton and this does not consider any detailed accuuncing for process and fabrication losses.

Further, electricity costs are likely to inflate faster than the economy as a whole.

The literature on energy consumption to produce single crystal silicon shows very wide variation in estimates. Since this value may be

\footnotetext{
*However, this may be due to differing assumption as to the state-of-the-art production processes.
} 
TABLE 16. BULK AND RAW MATERIALS VALUES

EXCEEDING $\$ 50.00$ PER KW INSTALLED

\begin{tabular}{|c|c|c|c|}
\hline Criticality & Material & $\begin{array}{c}300 \mathrm{GW} \\
\text { GaAs System }\end{array}$ & $\begin{array}{l}300 \mathrm{GW} \\
\text { Si System }\end{array}$ \\
\hline$A$ & Electricity & - & $\$ 143.00$ \\
\hline$A$ & Gallium & $\$ 118.00$ & - \\
\hline$A$ & Gallium Arsenide & 190.00 & - \\
\hline$A$ & Graphite Fiber (syn) & 53.00 & 44.00 \\
\hline A & Sapphire (syn) & 542.00 & - \\
\hline$A$ & Silicon (SEG) & - & 96.00 \\
\hline B & Petroleum & 80.00 & 82.00 \\
\hline B & Stee 1 & 99.00 & 99.00 \\
\hline
\end{tabular}

Criticality

A - Serious concern

B - Some concern

C - No concern 
very critical to evaluation of the SPS silicon option it seems imperative that the issue be reviewed in depth, and some common agreement reached on current values as well as the future outlook for reduction of those energy requirements.

Gallium. The price of Gallium probably does not bear strong relationehip to its cust uf production. As a mlnor material consftiuent in electronic devices, it is not highly price elastic, and its use is based on thique or superior performance properties. It is probably priced lherefore at what the market will bear. The recovery process is tedious and quality control for purity is undoubtedly costly, but it would seem very likely that recovery on the scale required by SPS could reduce costs and prices significantly.

On the other hand, to scale up gallium recovery to the level required for SPS would require assurance of market, since non-solar cell uses for gallium are apt to remain small. The future price for gallium is probably "negotiable" depending upon the quantities to be contracted.

Gallium Arsenide. The manufacture of single crystal gallium arsenide is still, a relatively crude art. Conslstant quality control and production rates are major problems. Even when efficient production processes are developed, the price of the material, is obviousiy going to be very dependent on the price of gallium.

Even with the very thin layers of gallium arsentide projected in the SPS reference designs, the material is a major cost driver.

The currenl price of gallium is about $\$ 800,000 / M T$. High purity arsenic (99.99y) is about $\$ 100,000 / \mathrm{MT}$. Epitaxially grown layers of GaAs are estimated at $\$ 700 / \mathrm{Kg}$. Th1s may be quite low. Single crystal GaAs produced from ingot is priced at about $\$ 30,000 / \mathrm{Kg}$. The cost of epitaxially grown layers needs further investigation.

Graphite Fiber, Synthetic. The current "average" price for graphite fiber used in reasonable conmercial quantities is about $\$ 26.00 / 1 \mathrm{~b}(\$ 57,200 / \mathrm{MT})$. If the price can be brought down to $\$ 5.00$ to $\$ 10.00$ per $\mathrm{lb}$, large scale use in the automobile industry is forecast. 
An automotive high volume commercial fiber would not be the very high modulus fiber currently used in some aerospace defense applications. Prices on high modulus grades are currently 10 to 20 times the "average" price used in the CMAP data base.

At present, a particular fiber grade has not been specified for SPS. Until further determination is made, we can only guess that the current graphite fiber cost contribution to SPS may be some 10 to 20 times higher than currently shown by CMAP. Undoubtedly significant cost reductions could be made even for the very high modulus fibers - in the volume contemplated by SPS.

Sapphire. In the bulk form of boules, sapphire costs about $\$ 800$ per $\mathrm{Kg}$. If boules are sliced to wafers, the cost is apt to be at least twice that; the thinner the wafer, the higher the cost per $\mathrm{Kg}$. Ribbon grown sapphire, which is relatively new, would appear to offer definite cost advantages if SPS specified thicknesses and widths can be achieved.

Synthetic sapphire production is very energy intensive and therefore is never apt to be costed lower than "hundreds of dollars" per $\mathrm{Kg}$. Pending further investigating sapphire appears as one of the highest cost contributions to SPS.

Single Crystal Silicon (SEG). A current price for "bulk" semi-conductor grade silicon is around $\$ 600.00$ per $\mathrm{Kg}$. Production of 50 micron wafers from single crystal ingot would entail very substantial process losses. A far more promising approach will probably involve ribbon growing processes--of which there are several under development.

High purity single crystal silicon is extremely energy intensive, and barring some radical technical innovation, it is apt to remain so. Production processes for high purfty polycrystalline silicon as well as single crystal silicon are under intense technical development at present. Without thorough review, any price projection would be very hazardous. In the case of SPS, the production and fabrication of 50 micron thicknesses of single crystal sillcun present many technical complexities. 
As a "bulk" material we would expect the relative price of single crystal silicon to decline. However, the technical complexities and consequently the costs of processing and fabricating 50 micron thick single crystal silicon material remain a very uncertain area.

Steel. The cost contribution of steel to the SPS system stems almost entirely from the nearly 3,000,000 metric tons of steel per year required for the rectenna insțallations in arrommodato two 5 CH sale1lites per year. That steel would probably be specified in basic mill structural shapes and therefore further fabrication custs would be minimal.

It would seem likely--that as a bulk material-the cost of steel is likely to inflate relatively faster than many of the other cost sensitive materials on the threshold list. This would stem from the relative maturity of the manufacture of steel compared to the new technology, cost-reducible materials that dominate the threshold list.

Petroleum. The cost contribution of petroleum derives very dominantly from its use as an energy source and not from its use ao $B$ chemical feedstock. Many industries rely on oil 'as their source of process heat and mechanical power.

Similar to the cost contribution of electricity, petroleum costs are apt to inflate faster than the other materials costs. Percent World Supply From One Nation, Non-U.S

This category of concern looks at the potential dominance of any one non-U.S. nation as a world supplier of bulk or raw material. For bulk materials, the threshold value is 35 percent. For raw materials the threshold is 60 percent.

Table 17 shows the bulk and raw materials exceeding these thresholds. 
TABLE 17. PERCENT OF WORLD SUPPLY FROM
ONE.NON-U.S. NATION

\begin{tabular}{lllc}
\hline \hline & Material & $\begin{array}{c}\text { Dominant } \\
\text { World } \\
\text { Supplier }\end{array}$ & $\begin{array}{c}\text { Percent } \\
\text { World } \\
\text { Supply }\end{array}$ \\
\hline C & Gallium & Switzerland & 40 \\
C & Graphite fiber & Japan & 35 \\
C & Titanium & USSR & 39 \\
C & Rutile (conc) & Australia & 98 \\
\hline \hline A - serious concern & & \\
B - possible concern & & \\
C - no concern. & & \\
\end{tabular}

Gallium. The predominant world supplier of gallium is one aluminum company in Switzerland. If gallium is to be produced in substantial quantities, that production would occur in a diverse number of countries that are the world's bauxite suppliers. It is very. unlikely that any one nation would dominate gallium supply. A possible, but unlikely, threat of cartelization could exlst.

Graphlte Fiber. Japan is a large world supplier of graphite fiber based upon proprietary technology. Similarly the U.K. is a major world supplier. U.S. production is also very substantial, and in response to U.S. demand, could be expanded almost wi thout limit.

Titanium. The dominant non-U.S. world producer is the USSR. This poses no real threat in that U.S. supply could be expanded substantially. U.S. Imports, largely from Japan, are estimated at about 8 percent of consumption. Further the SPS requirements for titanium are very small compared to total U.S. consumption. 
Rutile (conc). Rutile concentrate is the principal raw material for manufacturing titanium. Australia is by far the dominant world supplier. Other world sources of synthetic rutile derived. from 1lmenite are developing and these include the U.S. Further, since titanium demand by SPS is quite small, rutile requirements are also very small. 


\section{VI - SPS CRITICAL MATERIALS SUMMARY}

Assessment of SPS material requirements produced a number of potential material supply problems. The more serlous problems are those associated with the solar cell materials (gallfum; gallium arsenide, sapphire, and solar grade silicon), and the graphite fiber required for the satelite structure and space construction facilities. In general, the gallium arsenide SPS option exhibits more serious problems than the silicon option, possibly because gallium arsenide technology is not as well developed as that for silicon.

Table 18 summarizes potential material problems that have been identified. Problems of serious concern are denoted by an " $A$ " in the table, and those of lesser but possible concern are denoted by a " $B$ ". Within each of the two rating groups, materials are listed in order of decreasing criticality in terms of the number of different categories in which a problem exists (e.g., a material that exhibits a problem in'two categories is judged more critical than a material with a problem in only one category). Materials with problems in the same number of : categories are listed alphabetically.

The problems associated with each of the materials in the table are described in the following discussions.

\section{Marerlal Prublems of Serious Conccrn}

Gallium represents nearly 50 percent of the material required to produce the gallium arsentde active layer of the solar cells specified in the Gallium Arsenide option for SPS. SPS would require a minimum of $1470 \mathrm{MT} /$ year of gallium. Current world production is about 16 to $1 / \mathrm{Mr} /$ year.

A primary concern is that, with very rare exception, gallium does not naturally occur in concentrated ore deposits as do many other' elements. Well over 70 percent of current world gallium production is recovered as a by-product of the production of ajumina from bauxite. "Average" concentration of gallium in bauxite is considered to be about 
TABLE 18. SUMAARY OF ASSESSMENT RESULTS

\begin{tabular}{|c|c|c|c|c|c|c|}
\hline PARAMETER & $\begin{array}{l}\text { PERCENT } \\
\text { SUPPLIED } \\
\text { AS } \\
\text { BY-PRODUCT }\end{array}$ & $\begin{array}{l}\text { WORLD } \\
\text { PRODUCTION } \\
\text { GROWTH } \\
\text { RATE }\end{array}$ & $\begin{array}{c}\text { SPS } \\
\text { PERCENT } \\
\text { OF } \\
\text { DEMAND }\end{array}$ & \begin{tabular}{l}
\multicolumn{1}{c}{ NET } \\
PERCENT \\
IMPORTED
\end{tabular} & $\begin{array}{c}\text { PERCENT } \\
\text { WORLD } \\
\text { RESOURCE } \\
\text { CONSURITION }\end{array}$ & $\begin{array}{l}\text { COST } \\
\$ / K W\end{array}$ \\
\hline THRESHOLD VALUE * & $50 \%$ & $10 \%$ & $10 \%$ & $50 \%$ & $200 \%$ & $\$ 50 / \mathrm{KW}$ \\
\hline Gallium & $\mathbf{A}$ & - $\mathbf{A}$ & A & A & & \\
\hline Graphite Fiber & & $\mathbf{A}$ & A & & . & A \\
\hline Sapphire & & $\mathbf{A}$ & A & & & $\mathbf{A}$ \\
\hline SI11con SEG & & A. & A & , & . & $\mathbf{A}$ \\
\hline Galliun Arsenide & 1 & A & $\mathbf{A}$ & & . & $\mathbf{A}$ \\
\hline Electricity & & & $\cdot$ & & i & A \\
\hline $\begin{array}{l}\text { Arsenic/Arsenic } \\
\text { Trloxide }\end{array}$ & B & & & $\mathbf{B}$ & & \\
\hline Kapton & & B & B & 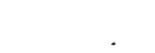 & & \\
\hline Oxygen ( $11 q)$ & & B & B & & & \\
\hline Silica Fiber & & B & B & . & & \\
\hline Silver & B & & & B & & \\
\hline Silver ore & & & . & B & B & \\
\hline Glass, borosil. & & . & B & & & \\
\hline Hydrogen (11q) & & $\dot{B}$ & & & & \\
\hline Mercury & & & & D & & \\
\hline Mercury ore & & & & $\mathbf{B}$ & & \\
\hline Methane & & B & - & & . & \\
\hline Potroleun & $\therefore$ & $\therefore$ & & & & B \\
\hline St eel &. & $\cdot$ & & . & & $\mathbf{B}$ \\
\hline Tungsten & ' & & & B & & \\
\hline
\end{tabular}

Note: "A" signifies prohlem of serious concern

" $B$ " signifies problem of posstble concern

* Parameter value above which a potential problem exists. Materials in this table exceeded these values where an " $A$ " or " $B$ " is recorded. 
50 parts per million. However, very few alumina producers currently recover by-product gallium. If sufficlent market demand and price incentives were present, many others most probably would.

The very dominant current use of gallium involves gallium arsenide in electronic applications. This use might grow at 6 to 7 percent per year. An SPS solar cell annual demand of $1470 \mathrm{MT}$ in year 2000 would completely dominate the market ( 97 percent) and require a world annual production growth rate of 85 percent beginning in 1995 to the year 2000. These are clearly formidable hurdles unless demand and price can be completely assured.

While world-wide processing of bauxite' to alumina could potentially easily accommodate this level of demand by a margin of 5 to 10 times, that processing step will increasingly occur in non U.S. locations. Currently the U.S. Is over 90 percent dependent on foreign bauxite or alumina and will become more so in the future. This; of course, means increasing dependency on foreign supply of gallium (currently estimated at about 55 percent) and an increasing potential for cartellization.

The current price of gallium is about $\$ 800,000 / \mathrm{MT}$. Gallium price is probably relatively inelastic in present markets. Given sufficient lead time for installation of new capacity and assured high levels of demand, that price level in large quantities is probably.very negotiable-downward. Because of its very low concentration in ore bodies, it is unlikely that gallium will ever be priced at less than "hundreds of thousands of dollars" per metric ton. Therefore, its price will continue to represent a very significant contribution to the overall cost of SPS.

A mitigating strategy to decrease foreign dependency for gallium might involve increasing domestic supply from non-bauxite sources. Increased domestic supply from zinc ores and possibly from coal are being investigated. 
Graphite Fiber. Graphite fiber reinforced thermoplastic (GFRTP) is specified as the structural support material for both SPS options. The composition is tentatively specified as 60 percent graphite fiber and 40 percent polysulfone thermoplastic. World consumption of graphite fiber in 1976 was about $215 \mathrm{MT}$. Based on potential substantial use by the automobile industry, it is projected to grow by about 15 percent/year to about $6,160 \mathrm{MT}$ by year 2000. SPS demand in 2000 of 12,700 to $15,300 \mathrm{MT} / \mathrm{yr}$ of GFRTP would require capacity growth of graphite fiber capacity by over, 30 percent/year beginning in 1995. SPS woulld also be very market dominant, requiring over 50 percent of world capacity.

It is also likely that SPS would require very high modulus graphite fiber. High modulus fiber is very costly, and represents a tiny fraction of today's production. Therefore, graphite fiber capacity to be added for SPS consumption would probably be very specialized. The market would need to be completely assured to bring forth this high level of very special fiber.

Material complications might be present if rayon were designated as the graphite fiber precursor. The rayon fiber currently used to manufacture high modulus graphite fiber is also "special". Current production capacity for that rayon fiber is less than half the annual requirements for SPS. Given present rayon market trends, current capacity for that special precursor fiber is very unlikely to be Increased without an assured market.

If polyacrylonitrile (PAN) fiber were used as the graphite fiber precursor, no raw material problems would be anticipated.

The current "average" price for graphite fiber purchased in reasonable commercial quantities is about $\$ 26.00 / 1 \mathrm{~b}(\$ 57,200 / \mathrm{MT})$. If that price can be brought down to $\$ 5.00$ to $\$ 10.00$ per $1 \mathrm{~b}$, large scale use in the automobile industry is forecast.

An automotive grade high volume commercial fiber would not be the very high modulus fiber currently used in some aerospace/defense applications. Prices on high modulus grades are currently 10 to 20 times the "average" price used in the CMAP data base. 
At present, a particular fiber grade has not been specified for SPS. Until further determination is made, we can only guess that the current graphite fiber cost contribution to SPS may be some 10 to 20 times higher than currently shown by CMAP. Undoubtedly significant cost reductions could be made even for the very high modulus fibers - - In the volume contemplated by SPS.

The major problems with graphite fiber then involve matters of manufacturing capacity and price. SPS designers should be aware of the implications of fiber specification on both these factors.

Regardless of fiber specifications, long lead time will be required to build the needed capacity. Some combination of advance procurement and assured markets will probably be needed.

Sapphire is specified as the substrate and cover for the GaAs solar cells. Sapphire is composed of crystalline $\mathrm{Al}_{2} \mathrm{O}_{3}$, hence no basic raw material problems exist.

Most synthetic sapphire is produced today as slices from single crystal boules, but ribbon growing technology is rapidly developing. The production level for synthetic sapphire in 1976 was probably about 10 metric tons, and today perhaps about 25 to $30 \mathrm{MT}$. Electronic applications are the major market drivers. At an estimated growth rate of about 20 percent/year, about $800 \mathrm{MT}$ would be produced in year 2000 . Therefore, very large increments of capacity would need to be added about 54 percent growth per year beginning in 1995. SPS demand would also be very market dominant, requiring about 78 percent of world output.

In the bulk form of boules, sapphire costs about $\$ 800$ per $\mathrm{kg}$. If boules are sliced to wafers, the cost is much greater; the thinner the wafer, the higher the cost per $\mathrm{kg}$. Ribbon grown sapphire, which is relatively new, would appear to offer definite cost advantages if SPS specified thicknesses and areas can be achieved.

Synthetic sapphire production is very energy intensive and therefore is never apt to be costed lower than "hundreds of dollars" per $\mathrm{kg}$. Pending further investigating sapphire appears as one of the highest cost contributions to the GaAs option for SPS. 
1. The U.S. is currently an exporter of synthetic sapphire single crystal, but the $r$ aw material ( 99.999 percent pure ground crystal) is almost all imported form Switzerland and France. Domestic production of the raw material was discontinued a few years ago, but could possibly be reestablished if the market continues its growth.

Mitigating strategies must involve rapid expansion of production capacity perhaps utilizing mechanisms such as advance procurement and assured market. Ribbon growing technology should be encouraged as a cost reducing measure.

Serious consideration should also be given to examining possibilities for substitution of other substrates for sapphire.

Single Crystal Silicon (SEG). Single crystal silicon between two layers of borosilicate glass is specified as the active layer of the silicon option solar array. Silicon crystals are essentially derived form $\mathrm{SiO}_{2}$, hence no raw material . problems exist.

U.S. consumption of semiconductor grade silicon (SEG) in 1976 was about $700 \mathrm{MT}$. Today, consumption might be about 1000 to $1200 \mathrm{MT}$, and applications are very largely electronic in nature.

Vespite a projected anmul growth rate of 20 percent/year, substantial additional capacity for silicon SEG would be required for SPS. Even if that projected growth rate for silicon SEG is realized, SPS would st 111 consume 11 percent of world production--an uncomfortable market position.

A current price for "bulk" semi-conductor grade silicon (single crystal) is around $\$ 600.00$ per $\mathrm{Kg}$. Production of 50 micron wafers from single crystal ingot would entail very zubotancial process losses. A far more promising approach will probably involve ribbon growing processes-of which there are several under development.

High purity single crystal silicon is extremely energy intensive, and barring some radical technical innovation, it is apt to remain so. Production processes for high purity polycrystalline silicon amorphous silicon, as well as single crystal silicon are under intense technical development at present. Without thorough review, any 
price projection would be very hazardous. In the cäse of SPS; the production and fabrication of 50 micron thicknesses of single crystal silicon present many technical complexities.

As a "bulk" material we would expect the relative price of single crystal silicon to decline. However, the technical complexities and consequently the costs of processing and fabricating 50 micron thick single crystal silicon material remain a very uncertain area.

Mitigating strategies for SPS should probably involve encouragement of single crystal ribbon growing technology. Because of the high efficiency/low mass requirements of SPS, lower cost polycrystalline or amorphous silicon active layers may not present practical alternatives. The silicon "industry" and silicon technology is expanding rapidly, hence SPS management may need to do little to encourage capacity increases. Other than encouragement of lower cost single crystal technology, the SPS stance might logicaily be "wait and see". Gallium Arsenide grown on a sapphire substrate is specified as the active layer of the solar array of the GaAs option."

Crystal growth of GaSa from melt is still a crude art. Epitaxial growth is considerably more advanced, but still a very slow. process. Less is known about epitaxial growth of GaAs on sapphire substrates.

Consequently, the timing of the development of true production processes for these materials in the quantities needed by SPS (about $2700 \mathrm{MT} / \mathrm{yr}$ ) is very speculative. We can assume that the development process may take at least 5 to 15 years. Therefore, starting in 1995 large increments of capacity ( 85 percent increase annually) would need to be built for a market that would be 97 percent dominated by SPS. This could only be accomplished under a system of assured markets.

Even with the very thin layers of gallium arsenide projected in the SPS reference designs, the material is a major cost driver.. The current price of gallium is about $\$ 800,000 / \mathrm{MT}$. High'purity arsentc. (99.999) is about $\$ 100,000 / \mathrm{MT}$. Epltaxially grown layers of GaAs are cotimatod at $\$ 700 / K_{g}$. (hir eistimate may be quite low. "Single crystal GaAs produced form ingot is priced at about $\$ 30,000 / \mathrm{Kg}$. 
If the gallium arsenide option for SPS is selected, SPS strategy (beyond the problems of gallium supply), should probably include enhancement of thin film GaAs technology. Much technology will need to be developed for deposition and handling of very thin films ( 5 microns) of GaAs on very thin substrates such as 20 micron sapphire. GaAs technology for terrestial solar cells is under very active development, but this technology will not be highly sensitive to mass.

'lhere will not likely be a GaAs "materials industry" as such. It is not yet clear whether active layers might preferably be deposited from the elements $\mathrm{Ga}$ and $A s$, the arsenide, or from chemical vapor depositon precursors such as trimethyl gallium -- $\mathrm{AsH}_{3}$.

Electricity. The consumption of electricity to produce solar cell materials is a significant contributing factor in the high cost of those materials. It also is a major contributor to the energy debt incurred in implementing photovoltaic (PV) systems -- a debt that must be repaid during a system's initial operational period before a net gain can be realized. In the case of the SPS a minimum of five to six months satellite operation would be required just to repay the energy consumed in producing its solar cell materials.

Present definitions of SPS solar cell production processes yield significantly higher electrical consumption for silicon cells than for gallium arsenide cells. However, this is probably due to the fact that the silicon process represents present or near term state-of-the-art while the gallium arsenide process is a projection of a more advanced state-of-the-art. Electrical consumption is a problem with both systems and is directly related to the problem of high solar materials costs. The viability of both system depends on the success of research on and development of more efficient production processes.

\section{Material Problems of Possible Concern}

Arsenic and Arsenic Trioxide are materials used in the production of gallium arsenide for that SPS option. The primary cause for concern is the environmental hazard that the production of these 
materlals represents. Arsentc and several of its compounds are listed in OSHA's Number I carcinogenic group. The only U.S. arsenic production facility is continuing 1 ts operation only by virtue of a court-ordered 5-year variance from Washington State air pollution standards. There is an abundant supply of the raw material from copper ores but product demand is not strong. In addition, the current annual production of the high purity $(99.999 \%)$ arsenic is less than 1 percent of the SPS annual requirement.

From the standpoint of the SPS the key question is: Will other demands for arsenic lead to production process improvements that will assure continued and even expanded production of the material? If not, then actions and investments may be required as part of a gallium, arsenide SPS program to resolve the problem. In any event production capacity of high purity arsenic will have to be greatly expanded.

Kapton. Kapton is used as a covering material for gallium arsenide solar cells in the gallium arsenide option. The only concern is that it is a proprletary product obtainable from a single source (Dupont), and the SPS would require a significant (100\%) growth rate in projected production capacity in the late 1990's. The combined effect of the unfavorable market positon and used for major industry expansion need in be assessed further.

Oxygen. Liquid oxygen is the oxidizer that would be used to burn fuels in all SPS chemical rocket stages used in the SPS space transportation system. When the SPS begins its operational phase in the year 2000 it would require over 2.7 million MT annually, representing about 7 percent of projected total world production. While the market percentage is not excessive, this requirement does represent a heavy demand for a cryogenic material that is difficult and expensive to store and transport. Dedicated on-site production facilities might be required. Further investigation of liquid oxygen supply requirements and their implications is needed. 
Silica, Fiber. Reusable launch vehicles required to transport SPS materials and personnel to low Earth orbit require heat shielding insulation to survive reentry. The present Space Shuttle utilizes silica tiles made from a special silica fiber as its primary heat shlelding system. The SPS cargo on personnel launch vehicles are assumed to use this same heat shielding material. Current production of the required silica fiber is very limited (only 5 Shuttles are currently planned). Production capacity would have to be increased significantily in the late 1990 's to produce the floet of vchicles fur the SPS. The growth rate required would be 46 percent per year for several years. Presently there is a single supplier of this special material used only in the reentry heat shielding application. This is an unfavorable market condition.

The severity of the silica problem is unclear. The silica approach to reentry vehicle heat shielding is very new (and as yet untried). Technology developments and operational experience in the $1980^{\prime}$ 's could lead to a significantly altered system or even to a totally different system in the $1990^{\prime} \mathrm{s}$. It is clear that whatever system is used the SPS would likely cause a material production capacity problem that wuld have to be dealt with.

Silver/Silver Ore. Silver represents a problém from several atandpoints. Silver recovery directly from silver ore (much of which is lupurted) represents : only 30 percent of total silver production. The Gallium Arsenide SPS design would require over 1 percent of the world's currently identifled silver.ore resources which are being depleted at a moderately significant rate. Howgver, actractive sllver prices continue to make by-product recovery of silver from copper, lead, and zinc ore economically desirable. In fact, by-product silver recovery can be a deciding factor in the exploitation of some of these ore bodies. On the other hand, trends toward on-site leaching of copper ores (rather than conventional milling) would reduce by-product silver recovery.

The net result of the above discussion is that the availability of adequate silver supplies in the year 2000 and beyond is somewhat in 
question. Assurance of an adequate supply would most likely come as a result of very high market prices. Thus it may be desirable to consider mitigating strategies to minimize the silver requirement such as design modifications and/or material substitution.

Borosilicate Glass is the cover/encapsulant material for the silicon solar cells in the silicon SPS option. Th1s glass with special themal properties is exemplifled by Pyrex. Production of sufficient quantities of the material will generate problems in production capacity growth and from a market domination point of view. In the late 1990's, the SPS would require a 6 percent annual production growth rate, and would consume about 12 percent of world requirements. In addition, producing and assembling the glass in the required 50 and 75 micron thicknesses will introduce substantial production complexities that will greatly increase material costs. These conditions may necessitate action (e.g. market assurance) and investments as part of the SPS program to assure production capacity growth and acceptable material prices.

Liquid Hydrogen is a fuel for various rocket stages used in the SPS space transportation system. Despite very large world production of hydrngen, liquid hydrogen is not a common market commodity. Much gaseous hydrogen is used captively by its producers. Liquid hydrogen for sale represents only about $1 / 2$ percent of total U.S. hydrogen production. NASA has been among ite largest consumers.

SPS requirements of 80,000 to 130,000 MT per year would represent 50 percent or more of expected non-captive liquid hydrogen production in the year 2000. Since liquid hydrogen (like liquid oxygen) is a cryogenic material that is difficult and expensive to transport and store, dedicated on-site production facilities may be needed. Further assessment is needed.

Mercury/Mercury Ore. Mercury is commonly used in electrical apparatus (e.g., switches) because it is a unique liquid phase conductor of electricity. Manufacture of electrical apparatus is the single largest domestic market (45 percent) for mercury. 
Both SPS options involve annual consumption of about $180 \mathrm{MT}$ of mercury which would represent about 9 percent of U.S. consumption in year 2000. Because of its toxicologically hazardous nature, mercury consumption in the U.S. Is expected to remain relatively flat at about 2000 MT annually. Consequently SPS demand should not present significant supply problems. However the U.S. Is currently 62 percent dependent on foreign sources of mercury/mercury ore. The world and domestic supply of mercury is quite price elastic, and under favorable price conditions; U.S. domestic supply could be significantly increased. While no major problems are anticipated, current U.S. dependence on a single domesic mercury producer is some cause for concern and should be closely monitored.

Methane. The rocket boosters that will launch elements of the SPS into orbit will require large quantities (650,000 MT annually) of high purity l1quid methane fuel which is not presently in demand*. There are three potential sources for that fuel: (1) naturally occurring deposits' (e.g. 99.5 percent pure methane is currently being recovered from natural gas wells in Alaska); distillation/separation from liquified natural gas (LNG), which may be avallable from various sources; and, (3) gasification of coal (and/or possibly biomass). For high purity natural gas and LNG there is a high degree of uncertainty as to how much of these fuels can be expected to be available in the year 2000 , where the major sources of supply w111 be located, and how much it will cost. If these supplies are inadequate, then the conal gasification option will have to be pursued and significant investments will be required to create this totally new supply.

Petroleum. Petroleum products are required as energy sources and as chemical feedstocks for many SPS materials. The primary concern

\footnotetext{
* Methane is normally the primary constituent of natural gas, although, content may vary from approximately 70 percent to near 100 percent. Most present uses of natural gas do not demand high purity methane -however, high purity deposits are belng depleted as part of the overall world consumption of natural gas.
} 
arises form its use as an energy source for process heat and mechanical power, where it represents a significant contribution to material costs ( $\$ 80 / \mathrm{KW}$ power installed). Similar to the cost contribution of electricity, petroleum costs are likely to inflate faster than the other material costs. From the SPS viewpoint it may be desirable to encourage DOE efforts to expand Industrial use of alternative energy sources.

Steel is the primary structural material for the SPS rectenna. Nearly 3,000,000 MT of steel per year will be required to support the installation of two $5 \mathrm{GW}$ rectennas per year. This extremely large requirement and the cost of steel ( $\$ 100 / \mathrm{KW}$ power installed) is a significant factor in overall SPS costs. Furthermore, since steel manufacturing is a mature industry, the situation is not likely to improve substantially and steel prices may be expected to inflate faster than many other materials on the SPS 1ist. Therefore it may prove desirable to minimize the steel requirement through rectenna redesign and/or material substitution where possible.

Tungsten. Both SPS optlons currently specify use of about 1300 MT/year of tungsten in heating elements for the klystrons. This would represent about 5 percent of U.S. tungsten consumption in year 2000. From 1976 to 2000 primary tungsten consumption in the U.S. should increase about 5 percent/year from a 1977 base of about 15,600 MT/year. Tungsten is sometimes a co-product or by-pioduct of molybdenum, copper, tin, blsmuth, gold and silver production. Co-product/by-product tungsten represents perhaps 10 percent of world supply. In the U.S., by-product/co-product production 1s nearer 30 percent. Domestically, the ore occurs often with molybdenum. (In the far-eastern countries, it often occurs with tin.) Tungsten is a strategic material and as such it commands attention. Steel industry demand for molybdenum should help to maintain co-product tungsten production in the U.S.

Currently the U.S. Imports over 50 percent of its tungsten requirements. Canada is a principal U.S. source, but the very dominant producer and world exporter of tungsten is the People's Republic of China. 
SPS consumption of tungsten would not beem to present "critical" dimensions, but its use should probably be minimized if suitable substitution alternatives exist. 
REFERENCES.

(1) "Solar Power Satellite Concept Evaluation Program", Department of . Energy and National Aeronautics and Space Administration, Washington, DC, October 1978.

(2) Litchfield, J.W., Watts, R. L., et al., "A Methodolgy for Identifying Materials Constraints to Implementation of Solar Energy Technologies", Battelle Pacific Northwest Laboratorles, Richland, WA, July, 1978.

(3) Commodity Data Summaries 1978. Bureau of Mines, U.S. Department of Interior, Washington, DC 1978.

(4) Mineral Facts and Problems (Biscentennial Edition). Bureau of . Mines. Bulletin 667, U.S. Department of Interior, Washington, DC 1975.

(5) Chemical Marketing Reporter (Weekly)., Schnell Publishing Co., New York, NY.

(6) Facts and Figures of the Plastics Industry. The Society of the Plastics Industry, New York, NY 10017; 1977.

(7) Chemical Statistics Handbook. Manufacturing Chemists Association, Washingtion, DC 20009, 1971.

(8) Modern Plastics. (Monthly).

(9) Current Industrial Reports. Series M30A, U.S. Department of Commerce, Bureau of Census, Washington, DC.

(10) Synthetic Organic Chemicals. U.S. International Trade Commission, Washingeon, DC.

(11) Current Industrial Reports. Series M32J, U.S. Department of Commerce, Bureau of Census, Washington, DC.

(12) Monthly Energy Review NTISUB/D/127-002 U.S. Department of Energy, Energy Information Administration, National Energy Information Center, 1978 .

(13) Young, J. F., Materials and Processes, Second edition, John Wiley and Sons, New York, 1954.

(14) ASM, Metals Handbook, Eighth edition, Volume 1, Properties and Selection of Metals, American Society for Metals, Metals Park, OH 1961 .

(15) ASM, Metals Handbook, 1948 edition, American Society for Metals, Metals Park, OH, 1948. 
REFERENCE (CONTINUED)

(16) Kingery, W. D., Introduction to Ceramics, John Wiley and Sons, New York, 1960.

(17) Data Book 1977, Metals Progress, Vol. 112, No. 1, June, 1977.

(18) 1975 Materials Selector, Materials Engineering, Vo1. 80, No. 4, September 1976.

(19) Unifled Numbering System for Metals and Alloys, Society for Automotive Englneers, Warrendale, PA, January, 1975.

(20) Energy Use Patterns in Metallurgical and Nonmetallic Mineral Processing, Bureau of Mines (Battelle, 1975).

(21) Industrial Chemicals, Farth, Keyes, and Clark, 4th Edition.

(22) Chemical Economics Handbook, Stanford Research Institute, Menlo Park, California..

(23) Sources and Production Economics of Chemical Products, McGrawHill, 1974. 


\section{APPENDIX A}

This appendix presents the materials assessment data base as it was used for the SPS study. Table A-1 contains the bulk materials screening data on materials availability, cost, consumption, and import dependency. Table $\mathrm{A}-2$ is the raw materials screening data--similar to that for bulk materials (Table 1), but also containing current estimates of U.S. and World reserves and resources. Table A-3 contains the engineering material to bulk material conversions, and Table A-4 summarizes bulk material production processes. Quantities shown in Table A-4 are those needed to produce one metric ton (MT) of the desired material.

This data base represents an updating and upgrading of that used in previous materials assessment studies (References 1-3). These changes include:

- Additions required for SPS:

- engineering materials

- bulk materials

- raw materials

- Conversion of data base from gross imports to net imports

- Updating various data parameters to 1976 actual values as published by U.S. Bureau of Mines. (Previous data were 1976 estimates of consumption, reserves, imports, etc.)

- Bulk material prices were updated to January 1, 1979

- Incorporation of intermediate bulk materials into the bulk to raw conversion data

- A number of recalculations and corrections. 
TABLE: A-1. BULK MATERIAL DATA SUMMARY

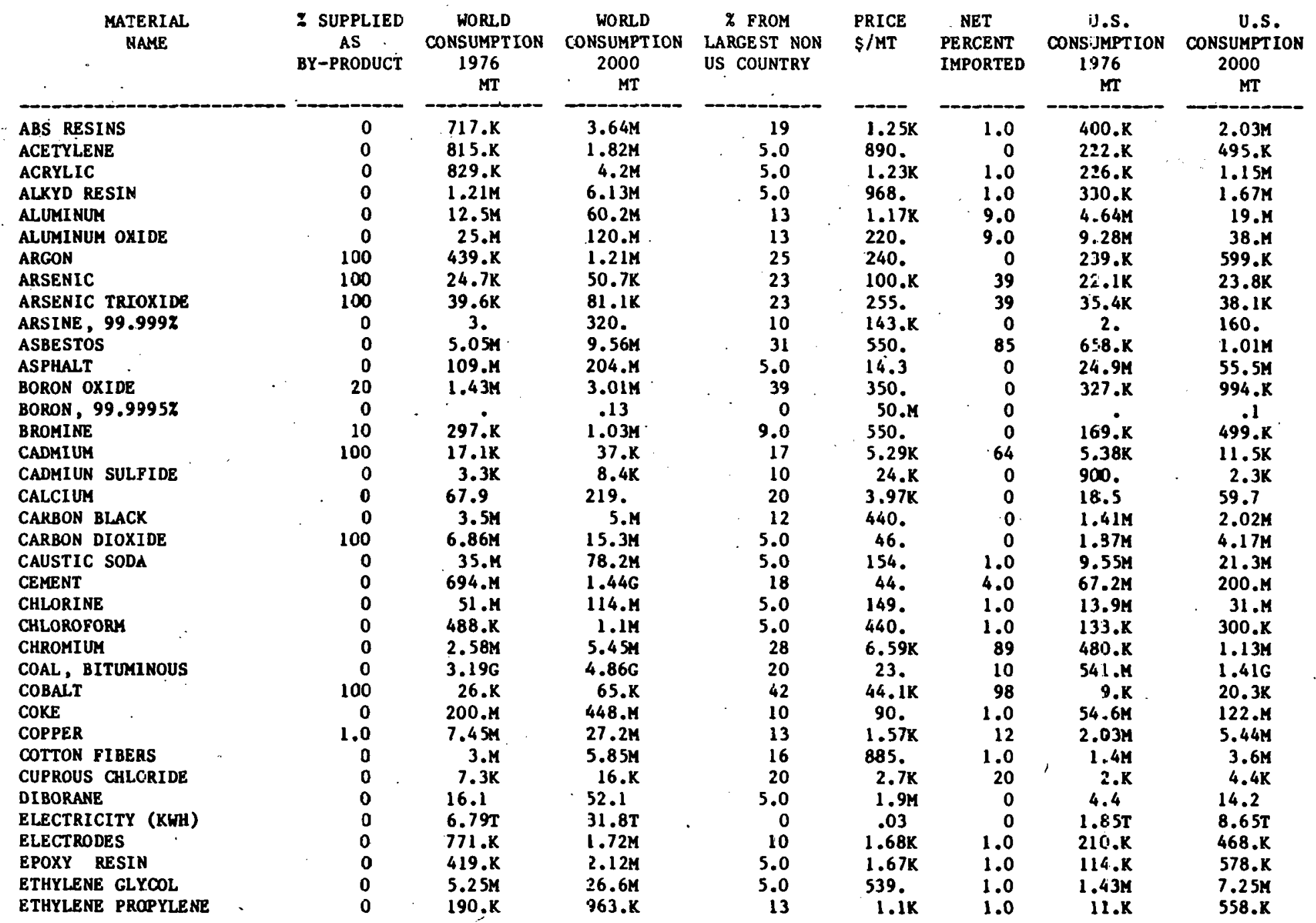

$K=10^{3}, H=10^{6}, G=10^{9}$, and $T=10^{12}$.

MT = Metric tons 
TABLE A-1. BULX MATERIAL DATA SUMmaRY (CONTINUED)

$11 / 20 / 79$

\begin{tabular}{|c|c|c|c|c|c|c|c|c|}
\hline $\begin{array}{c}\text { MATERIAL } \\
\text { NAME }\end{array}$ & $\begin{array}{l}x \text { SUPPLIED } \\
\text { AS } \\
\text { BY-PRODUCT }\end{array}$ & $\begin{array}{l}\text { WORLD } \\
\text { CONSUMPTION } \\
1976 \\
\text { MT }\end{array}$ & $\begin{array}{l}\text { WORLD } \\
\text { CONSUMPTION } \\
2000 \\
\text { MT }\end{array}$ & $\begin{array}{l}\text { } 7 \text { FROM } \\
\text { LARGEST NON } \\
\text { US COUNTRY }\end{array}$ & $\begin{array}{l}\text { PRICE } \\
\text { \$/MT }\end{array}$ & $\begin{array}{l}\text { NET } \\
\text { PERCENT } \\
\text { IMPORTED }\end{array}$ & $\begin{array}{c}\text { U.S: } \\
\text { CONSUMPTION } \\
1976 \\
\text { MT }\end{array}$ & $\begin{array}{c}\text { U.S. } \\
\text { CONSUMPTION } \\
2000 \\
\text { MT }\end{array}$ \\
\hline FERROUS SCRAP, PURCHASED & 0 & $138 . M$ & 307.M & 10 & 85. & 0 & $37.5 M$ & $83.6 M$ \\
\hline FLUORINE & 8.0 & $2.03 \mathrm{M}$ & $6.51 \mathrm{M}$ & 19 & $1.3 \mathrm{~K}$ & 79 & $432 . \mathrm{K}$ & $1.71 \mathrm{M}$ \\
\hline FLUORSPAR & 0 & $4.61 M$ & $14.8 \mathrm{M}$ & 19 & 125. & 79 & $982 . K$ & $3.91 \mathrm{M}$ \\
\hline GALLIUM & 100 & 16.8 & 47 & 40 & $800 . \mathrm{K}$ & 55 & 8.88 & 32. \\
\hline GALLIUM ARSENIDE (DEP) & 0 & 26. & 84.3 & -10 & $700 . K$ & 0 & 14. & 45.4 \\
\hline GALLIUM ARSENIDE (INGOT) & 0 & 11.1 & 57.8 & 10 & 3.M & $\mathbf{0}$ & 8.9 & 35.5 \\
\hline GALLIUM ARSENIDE (WAFER) & 0 & 5. & 26. & 10 & $7 . M$ & 0 & 4. & 16. \\
\hline GERMANE, 99.97 & 0 & .04 & .16 & 5.0 & $350 . \mathrm{K}$ & $\mathbf{0}$ & .03 & .08 \\
\hline GERMAN I UM & 100 & 79.4 & 127. & 29 & $316 . K$ & 16 & 21.3 & 36.7 \\
\hline GLASS, BOROSILIC & 0 & $117 . \mathrm{K}$ & 262.K & 5.0 & 735. & 1.0 & $32 . K$ & $71.4 \mathrm{~K}$ \\
\hline GLASS, FIBER & 0 & $771 . \mathrm{K}$ & $7.22 \mathrm{M}$ & 5.0 & $1.35 \mathrm{~K}$ & 2.0 & $210 . \mathrm{K}$ & $1.97 \mathrm{M}$ \\
\hline GLASS, SODA LIME & 0 & $68.3 \mathrm{M}$ & $117 . M$ & 5.0 & 340 & 1.0 & $18.6 \mathrm{M}$ & $32 . M$ \\
\hline GOLD & 47 & $1.2 \mathrm{~K}$ & $2.01 \mathrm{~K}$ & 58 & $6.43 \mathrm{M}$ & 76 & 145. & 528. \\
\hline GRAPHITE FIBER, SYNTHETIC & 0 & 215. & $6.16 \mathrm{~K}$ & 35 & $57.2 \mathrm{~K}$ & 0 & 118. & $3.38 \mathrm{~K}$ \\
\hline GRAPHITE, MFGD. & $\mathbf{0}$ & $1.2 \mathrm{M}$ & $2.67 M$ & 10 & $8.7 \mathrm{~K}$ & 1.0 & $326 . K$ & $727 . K$ \\
\hline GYPSUM, CALCINED & 5.0 & $64.6 M$ & $113 . M$ & 10 & 28 & 35 & $16.3 \mathrm{M}$ & $31.6 \mathrm{M}$ \\
\hline HELIUM & 100 & $10.6 \mathrm{~K}$ & $23.7 \mathrm{~K}$ & 5.0 & $4.37 \mathrm{~K}$ & 0 & $2.9 \mathrm{~K}$ & $6.47 \mathrm{~K}$ \\
\hline HYDROCHLORIC ACID & 92 & $8.33 \mathrm{M}$ & $18.6 \mathrm{M}$ & 5.0 & 200. & 2.0 & $2.27 M$ & $5.06 \mathrm{M}$ \\
\hline HYDROFLUORIC ACID & $\mathbf{0}$ & $947 . \mathrm{K}$ & $2.11 \mathrm{M}$ & 15 & 981 . & 0 & $258 . K$ & 575.K \\
\hline HYDROGEN & 40 & $22 . M$ & $90 . \mathrm{M}$ & 10 & 600 . & 0 & $7.9 M$ & $37 . M$ \\
\hline HYDROGEN SULFIDE, 99.9992 & $\mathbf{0}$ & - & .01 & 10 & 195.K & 0 & - & - \\
\hline INDIUM & 100 & 46.5 & 103. & 20 & $338 . \mathrm{K}$ & 24 & 37.6 & 47.3 \\
\hline INDIUM-TIN OXIDE & 0 & 15 & 24. & 10 & $320 . K$ & 0 & 9. & 12. \\
\hline KAPTON &,$\quad 0$ & $1 . \mathrm{K}$. & $5.06 \mathrm{~K}$ & 0 & $66 . K$ & 5.0 & 273. & $1.38 \mathrm{~K}$ \\
\hline KRAFT FIBERS & $\mathbf{0}$ & $60 . M$ & 120.M & 10 & 425. & 15 & 28.M & $60 . \mathrm{M}$ \\
\hline LEAD & 13 & $3.35 \mathrm{M}$ & $10.6 \mathrm{M}$ & 12 & 838. & 15 & $1.38 \mathrm{M}$ & $2.2 \mathrm{M}$ \\
\hline LIME & $\mathbf{0}$ & 105.M & $217 . M$ & 20 & 34. & 2.0 & $18.6 \mathrm{M}$ & $39.3 \mathrm{M}$ \\
\hline LINSEED OIL & 0 & $1.5 \mathrm{M}$ & $2 . M$ & 5.0 & $1.03 \mathrm{~K}$ & 1.0 & $230 . x$ & $290 . \mathrm{K}$ \\
\hline LIQUID FUELS & 0 & $2.72 \mathrm{G}$ & $5.4 G$ & 18 & 123. & 39 & $631 . M$ & $1.47 \mathrm{G}$ \\
\hline LITRIUM & 4.0 & $7.5 \mathrm{~K}$ & $27 . K$ & 2.0 & $32 . \mathrm{K}$ & 0 & $2.64 \mathrm{~K}$ & 13.18 \\
\hline LUMBER, SOFTWOOD & 0 & $300 . M$ & $780 . M$ & 20 & 188. & 12 & $70 . M$ & $180 . M$ \\
\hline MAGNESIUM & 1.0 & $229 . \mathrm{K}$ & $889 . K$ & 27 & $2.23 \mathrm{~K}$ & 0 & $94.3 \mathrm{~K}$ & $358 . \mathrm{K}$ \\
\hline MERCURY & 2.0 & $8.4 \mathrm{~K}$ & $10.2 \mathrm{~K}$ & 18 & $4.5 K$ & 62 & $2.36 \mathrm{~K}$ & 2.K \\
\hline METHANOL & 0 & $6 . M$ & $19.4 \mathrm{M}$ & 10 & 146. & 0 & $2.71 \mathrm{M}$ & $8.75 \mathrm{M}$ \\
\hline MOLYBDENUM & 42 & $86.8 \mathrm{~K}$ & $266 . K$ & 17 & $11.7 \mathrm{~K}$ & 0 & $27.1 \mathrm{~K}$ & $87.5 \mathrm{~K}$ \\
\hline
\end{tabular}

$K=10^{3}, M-10^{6}, G=10^{9}$, and $T=10^{12}$.

MT = Metric tons 
TABLE A-1. BULK MATERIAL DATA SUMMARY

(CONTINUED)

$11 / 20 / 79$

\begin{tabular}{|c|c|c|c|c|c|c|c|c|}
\hline $\begin{array}{l}\text { MATERIAL } \\
\text { NAME }\end{array}$ & $\begin{array}{c}7 \text { SUPPLIEE: } \\
\text { AS } \\
\text { BY-PRODUCT }\end{array}$ & $\begin{array}{l}\text { WORLD } \\
\text { CONSUMPT ION } \\
1976 \\
\text { MT }\end{array}$ & $\begin{array}{l}\text { WORLD } \\
\text { CONSUMPTION } \\
2000 \\
\text { MT }\end{array}$ & \begin{tabular}{l}
\multicolumn{1}{c}{ X FROM } \\
LARGEST NON \\
US COUNTRY
\end{tabular} & $\begin{array}{l}\text { PRICE } \\
\text { S/MT }\end{array}$ & $\begin{array}{l}\text { NET } \\
\text { PERCENT } \\
\text { IMPORTED }\end{array}$ & $\begin{array}{c}\text { U.S. } \\
\text { CONSUMPTION } \\
1976 \\
\text { MT }\end{array}$ & $\begin{array}{c}\text { U.S. } \\
\text { CONSUMPTION } \\
2000 \\
\text { MT }\end{array}$ \\
\hline 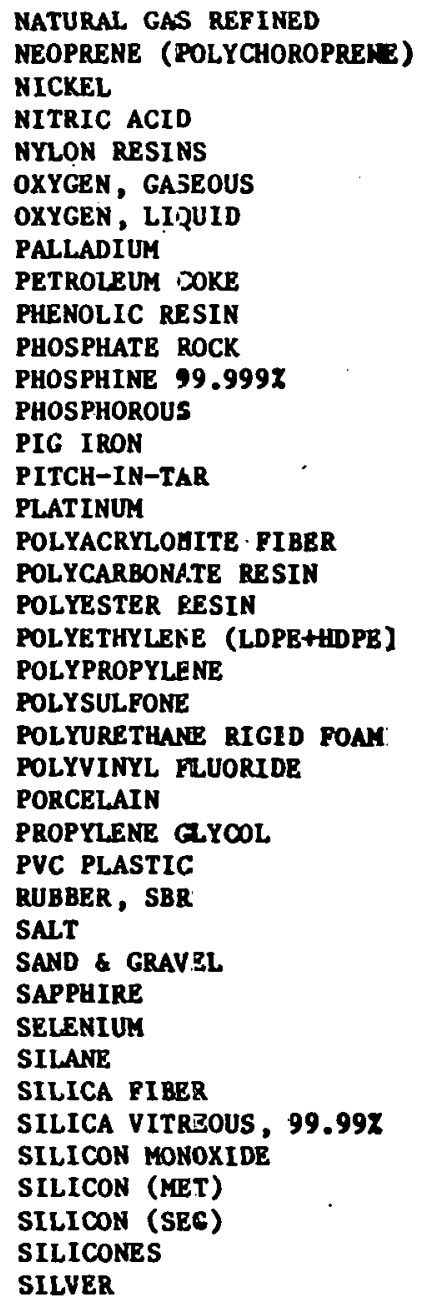 & $\begin{array}{r}0 \\
0 \\
7.0 \\
0 \\
0 \\
0 \\
0 \\
100 \\
100 \\
0 \\
0 \\
0 \\
0 \\
0 \\
0 \\
100 \\
0 \\
0 \\
0 \\
0 \\
0 \\
0 \\
0 \\
0 \\
0 \\
0 \\
0 \\
0 \\
0 \\
0 \\
0 \\
100 \\
0 \\
0 \\
0 \\
0 \\
0 \\
0 \\
0 \\
70\end{array}$ & $\begin{array}{c}1.01 \mathrm{G} \\
404 . \mathrm{K} \\
804 . \mathrm{K} \\
46.8 \mathrm{M} \\
341 . \mathrm{K} \\
35.5 \mathrm{M} \\
15.2 \mathrm{M} \\
76.6 \\
55.7 \mathrm{M} \\
2.18 \mathrm{M} \\
107 . \mathrm{M} \\
2.5 \\
14.3 \mathrm{M} \\
487 . \mathrm{M} \\
757 . \mathrm{K} \\
87.8 \\
1.72 \mathrm{M} \\
100 . \mathrm{K} \\
1.6 \mathrm{M} \\
11 . \mathrm{M} \\
2.81 \mathrm{M} \\
18.4 \mathrm{~K} \\
635 . \mathrm{K} \\
10.5 \mathrm{~K} \\
543 . \mathrm{K} \\
870 . \mathrm{K} \\
8.36 \mathrm{M} \\
3.19 \mathrm{M} \\
166 . \mathrm{M} \\
6.49 \mathrm{G} \\
20 . . \\
1.26 \mathrm{~K} \\
30 . \\
41.9 \\
1.8 \mathrm{~K} \\
18 . \mathrm{K} \\
2.21 \mathrm{~K} \\
1.4 \mathrm{~K} \\
266 . \mathrm{K} \\
9.48 \mathrm{~K}\end{array}$ & $\begin{array}{c}3.04 \mathrm{G} \\
899 . \mathrm{K} \\
1.81 \mathrm{M} \\
104 . \mathrm{M} \\
1.73 \mathrm{M} \\
93.8 \mathrm{M} \\
40.2 \mathrm{M} \\
188 . \mathrm{M} \\
110 . \mathrm{M} \\
11.1 \mathrm{M} \\
414 . \mathrm{M} \\
240 . \mathrm{M} \\
55.4 \mathrm{M} \\
1.05 \mathrm{G} \\
1.4 \mathrm{MM} \\
180 . \\
3.84 \mathrm{M} \\
507 . \mathrm{K} \\
8.11 \mathrm{M} \\
20.5 \mathrm{M} \\
14.2 \mathrm{M} \\
93.3 \mathrm{~K} \\
3.22 \mathrm{M} \\
53.2 \mathrm{~K} \\
1.21 \mathrm{M} \\
4.41 \mathrm{H} \\
42.4 \mathrm{M} \\
16.2 \mathrm{M} \\
686 . \mathrm{M} \\
15.7 \mathrm{G} \\
1.6 \mathrm{~K} \\
3.49 \mathrm{~K} \\
2.7 \mathrm{~K} \\
83.8 \\
4 . \mathrm{K} \\
40 . \\
4.72 \mathrm{M} \\
111 . \mathrm{K} \\
591 . \mathrm{K} \\
26.1 \mathrm{~K}\end{array}$ & $\begin{array}{r}23 \\
5.0 \\
33 \\
32 \\
20 \\
21 \\
21 \\
47 \\
15 \\
13 \\
22 \\
10 \\
22 \\
22 \\
5.0 \\
47 \\
18 \\
10 \\
5.0 \\
14 \\
18 \\
5.0 \\
5.0 \\
5.0 \\
5.0 \\
5.0 \\
19 \\
14 \\
18 \\
10 \\
25 \\
37 \\
10 \\
0 \\
10 \\
20 \\
12 \\
10 \\
5.0 \\
14\end{array}$ & $\begin{array}{c}94 . \\
1.32 \mathrm{~K} \\
4.59 \mathrm{~K} \\
116 . \\
2.55 \mathrm{~K} \\
20 . \\
18 \\
2.17 \mathrm{~K} \\
84 . \\
1.03 \mathrm{~K} \\
22 . \\
187 . \mathrm{K} \\
1.21 \mathrm{~K} \\
210 . \\
33.1 \\
10.7 \mathrm{~K} \\
1.63 \mathrm{~K} \\
2.49 \mathrm{~K} \\
792 . \\
693 . \\
726 . \\
4.4 \mathrm{~K} \\
3.85 \mathrm{~K} \\
19.8 \mathrm{~K} \\
2.2 \mathrm{~K} \\
561 . \\
594 . \\
748 . \\
49 . \\
2.18 \\
800 . \mathrm{K} \\
39.7 \mathrm{~K} \\
130 . \mathrm{K} \\
300 . \mathrm{K} \\
106 . \mathrm{K} \\
120 . \mathrm{K} \\
1.07 \mathrm{~K} \\
60 . \mathrm{K} \\
6.27 \mathrm{~K} \\
196 . \mathrm{K}\end{array}$ & $\begin{array}{r}5.0 \\
6.0 \\
70 \\
1.0 \\
2.0 \\
0 \\
0 \\
90 \\
0 \\
1.0 \\
0 \\
0 \\
0 \\
0 \\
5.0 \\
90 \\
3.0 \\
1.0 \\
1.0 \\
1.0 \\
0 \\
5.0 \\
1.0 \\
5.0 \\
0 \\
5.0 \\
1.0 \\
4.0 \\
7.0 \\
0 \\
0 \\
59 \\
0 \\
4.0 \\
0 \\
30 \\
11 \\
0 \\
1.0 \\
50\end{array}$ & $\begin{array}{c}406 . M \\
110 . K \\
198 . K \\
7.17 M \\
100 . K \\
10.1 M \\
4.32 M \\
27.3 \\
12.9 M \\
533 . K \\
31.1 M \\
1.5 \\
4.17 M \\
78.9 M \\
349 . K \\
31.3 \\
285 . K \\
51 . K \\
436 . K \\
4.04 M \\
1.15 M \\
5 . K \\
173 . K \\
4.68 K \\
148 . K \\
237 . K \\
2.11 M \\
1.23 M \\
43.1 M \\
800 . M \\
10 . \\
44 B . \\
17 . \\
1.9 \\
50.9 . \\
54 . \\
54 B . K \\
700 . \\
72.4 K \\
5.3 K\end{array}$ & $\begin{array}{c}551 . M \\
245 . K \\
499 . K \\
16 . M \\
507 . K \\
39.3 \mathrm{M} \\
16.9 \mathrm{M} \\
49.2 \\
30 . \mathrm{M} \\
3.01 \mathrm{M} \\
62.6 \mathrm{M} \\
120 . \\
8.39 \mathrm{M} \\
148 . \mathrm{M} \\
890 . \mathrm{K} \\
44.8 \\
636 . \mathrm{K} \\
259 . \mathrm{K} \\
2.2 \mathrm{M} \\
20.5 \mathrm{M} \\
5.83 \mathrm{M} \\
25.4 \mathrm{~K} \\
877 . \mathrm{K} \\
23.7 \mathrm{~K} \\
330 . \mathrm{K} \\
1.2 \mathrm{M} \\
10.7 \mathrm{~K} \\
6.24 \mathrm{H} \\
124 . \mathrm{H} \\
1.9 \mathrm{G} \\
800 . \\
1.41 \mathrm{~K} \\
1.35 \mathrm{~K} \\
3.8 \\
1.1 \mathrm{~K} \\
11 . \\
1.09 \mathrm{M} \\
55.6 \mathrm{~K} \\
161 . \mathrm{K} \\
9.64 \mathrm{~K}\end{array}$ \\
\hline
\end{tabular}

$K=10^{3}, M=10^{6}, G=10^{9}$, and $T=10^{12}$.

MT $=$ Metric tons 
TABLE A-1 . BULK MATERIAL DATA SUMmARY (CONTINUED)

$11 / 20 / 79$

\begin{tabular}{|c|c|c|c|c|c|c|c|c|}
\hline $\begin{array}{c}\text { MATERIAL } \\
\text { NAME }\end{array}$ & $\begin{array}{l}\text { X SUPPLIED } \\
\text { AS } \\
\text { BY-PRODUCT }\end{array}$ & $\begin{array}{l}\text { HORLD } \\
\text { CONSUMPTION } \\
1976 \\
\text { MT }\end{array}$ & $\begin{array}{l}\text { HORLD } \\
\text { CONSUMPTION } \\
2000 \\
\text { MT }\end{array}$ & $\begin{array}{l}\text { X FROM } \\
\text { LARGEST NON } \\
\text { US COUNTRY }\end{array}$ & $\begin{array}{l}\text { PRICE } \\
\$ / \mathrm{MT}\end{array}$ & \begin{tabular}{l}
\multicolumn{1}{c}{ NET } \\
PERCENT \\
IMPORTED
\end{tabular} & $\begin{array}{c}\text { U.S. } \\
\text { CONSUMPT ION } \\
1976 \\
\text { MI }\end{array}$ & $\begin{array}{c}\text { U.S. } \\
\text { CONSUMPTION } \\
2000 \\
\text { MT }\end{array}$ \\
\hline 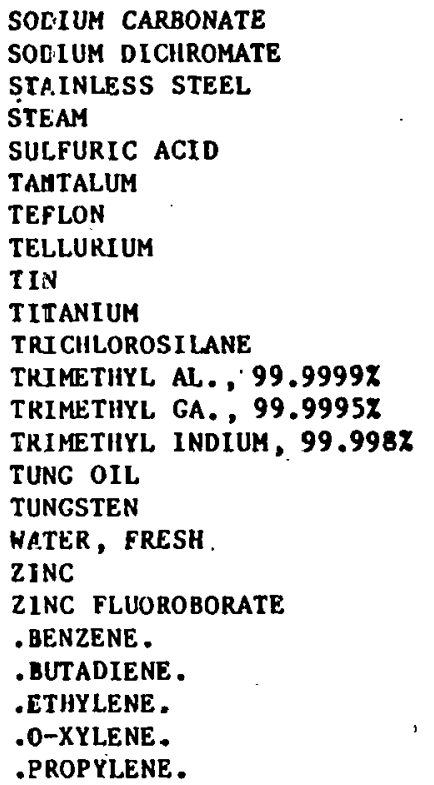 & $\begin{array}{r}0 \\
0 \\
0 \\
1.0 \\
20 \\
100 \\
0 \\
100 \\
1.0 \\
0 \\
0 \\
0 \\
0 \\
0 \\
0 \\
10 \\
0 \\
25 \\
0 \\
0 \\
40 \\
0 \\
0 \\
25\end{array}$ & $\begin{array}{l}18.5 \mathrm{M} \\
477 . \mathrm{K} \\
6.45 \mathrm{M} \\
2.57 \mathrm{G} \\
144 . \mathrm{M} \\
1.36 \mathrm{~K} \\
11.8 \mathrm{~K} \\
260 . \\
226 . \mathrm{K} \\
5 ? .1 \mathrm{~K} \\
8.45 \mathrm{~K} \\
.25 \\
.08 \\
.04 \\
45 . \mathrm{K} \\
4 \mathrm{D} .7 \mathrm{~K} \\
1.6 \mathrm{~T} \\
5.86 \mathrm{M} \\
3.5 \\
9.13 \mathrm{M} \\
3.32 \mathrm{M} \\
37.4 \mathrm{M} \\
2.37 \mathrm{M} \\
16.7 \mathrm{M}\end{array}$ & $\begin{array}{l}11.5 \mathrm{M} \\
1.06 \mathrm{M} \\
16.5 \mathrm{M} \\
5.72 \mathrm{G} \\
308 . \mathrm{M} \\
4.17 \mathrm{~K} \\
59.8 \mathrm{~K} \\
349 . \\
410 . \mathrm{K} \\
213 . \mathrm{K} \\
92 . \mathrm{K} \\
1 . \mathrm{K} \\
.32 \\
.16 \\
45.1 \mathrm{~K} \\
80.2 \mathrm{~K} \\
2.86 \mathrm{~T} \\
10.5 \mathrm{M} \\
8 . \\
29.4 \mathrm{M} \\
10.7 \mathrm{M} \\
12.1 \mathrm{M} \\
5.33 \mathrm{M} \\
53.9 \mathrm{M}\end{array}$ & $\begin{array}{r}10 \\
5.0 \\
30 \\
10 \\
14 \\
24 \\
10 \\
21 \\
28 \\
39 \\
10 \\
5.0 \\
5.0 \\
5.0 \\
45 \\
7.0 \\
5.0 \\
20 \\
25 \\
16 \\
14 \\
13 \\
12 \\
14\end{array}$ & $\begin{array}{c}64 . \\
815 . \\
1.37 \mathrm{~K} \\
4.25 \\
55 . \\
143 . \mathrm{K} \\
6.82 \mathrm{~K} \\
44.1 \mathrm{~K} \\
16.4 \mathrm{~K} \\
7.23 \mathrm{~K} \\
1.98 \mathrm{~K} \\
5 . \mathrm{M} \\
8 . \mathrm{M} \\
35 . \mathrm{M} \\
2.2 \mathrm{~K} \\
32.4 \mathrm{~K} \\
4.25 \\
760 . \\
2.85 \mathrm{~K} \\
239 . \\
451 . \\
286 . \\
248 . \\
220 .\end{array}$ & $\begin{array}{r}0 \\
1.0 \\
15 \\
0 \\
0 \\
96 \\
8.0 \\
53 \\
85 \\
8.0 \\
0 \\
0 \\
0 \\
0 \\
70 \\
54 \\
0 \\
59 \\
0 \\
1.0 \\
16 \\
0 \\
0 \\
0\end{array}$ & $\begin{array}{c}1.57 \mathrm{M} \\
130 . \mathrm{K} \\
1.03 \mathrm{M} \\
700 . \mathrm{M} \\
30 . \mathrm{M} \\
602 . \\
7.08 \mathrm{~K} \\
173 . \\
65.4 \mathrm{~K} \\
21.1 \mathrm{~K} \\
4.65 \mathrm{~K} \\
.15 \\
.05 \\
.03 \\
15 . \mathrm{K} \\
7.81 \mathrm{~K} \\
437 . \mathrm{G} \\
1.03 \mathrm{M} \\
1 . \\
4.9 \mathrm{M} \\
1.73 \mathrm{M} \\
10.2 \mathrm{~K} \\
388 . \mathrm{K} \\
4.55 \mathrm{M}\end{array}$ & $\begin{array}{c}64.4 \mathrm{M} \\
2.4 \mathrm{~K} \\
35.9 \mathrm{~K} \\
231 . \\
81.3 \mathrm{~K} \\
63.5 \mathrm{~K} \\
45.8 \mathrm{~K} \\
.5 \\
.16 \\
.08 \\
15.1 \mathrm{~K} \\
23.5 \mathrm{~K} \\
778 . \mathrm{G} \\
2.49 \mathrm{M} \\
2.2 \\
15.8 \mathrm{M} \\
5.59 \mathrm{M} \\
32.9 \mathrm{M} \\
865 . \mathrm{K} \\
14.7 \mathrm{M}\end{array}$ \\
\hline
\end{tabular}

$K=10^{3}, M=10^{6}, G-10^{9}$, and $T=10^{12}$.

$M T=$ Metric tons 
TABLE A-2. RAW MATERIAL DATA SUMMARY

$11 / 20 / 79$

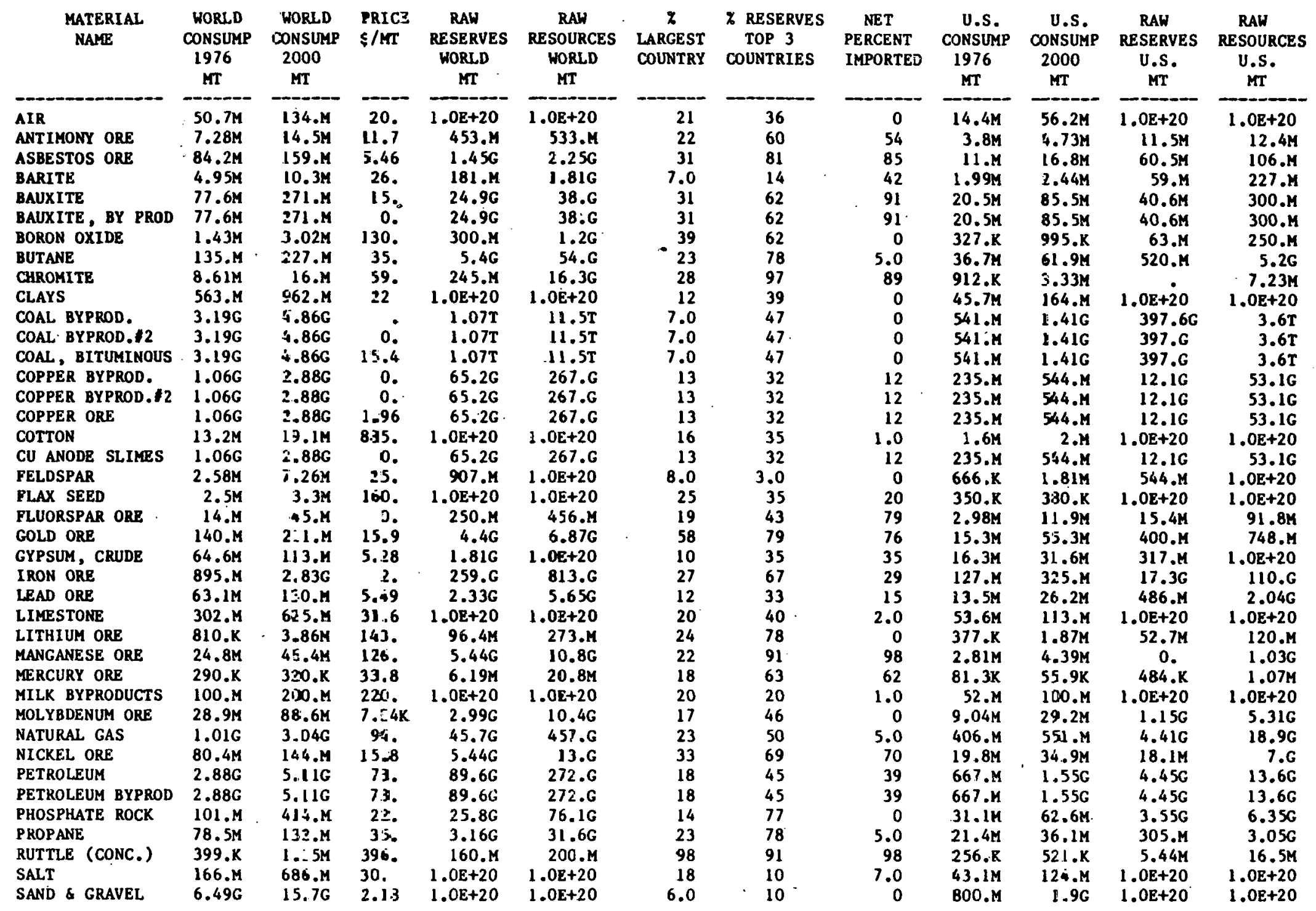


TABLE A-2, RAW MATERIAL DATA SUMMARY (CONTINUED)

$11 / 20 / 79$

\begin{tabular}{|c|c|c|c|c|c|c|c|c|c|c|c|c|}
\hline $\begin{array}{l}\text { MATERLAL } \\
\text { NAYE }\end{array}$ & $\begin{array}{l}\text { WORLD } \\
\text { CONSUMP } \\
1976 \\
\text { MT }\end{array}$ & $\begin{array}{l}\text { WORLD } \\
\text { CONSUMP } \\
2000 \\
\text { MT }\end{array}$ & $\begin{array}{l}\text { PRICE } \\
\text { \$/MT }\end{array}$ & $\begin{array}{c}\text { RAW } \\
\text { EESERVES } \\
\text { WORLD } \\
\text { MT }\end{array}$ & $\begin{array}{c}\text { RAW } \\
\text { RESOURCES } \\
\text { WORLD } \\
\text { MT }\end{array}$ & $\begin{array}{c}x \\
\text { LARGE ST } \\
\text { COUNTRY }\end{array}$ & $\begin{array}{l}7 \text { RESERVES } \\
\text { TOP } 3 \\
\text { COUNTRIES }\end{array}$ & $\begin{array}{l}\text { NET } \\
\text { PERCENT } \\
\text { IMPORTED }\end{array}$ & $\begin{array}{c}\text { U.S. } \\
\text { CONSUMP } \\
1976 \\
\text { MT }\end{array}$ & $\begin{array}{c}\text { U.S. } \\
\text { CONSUMP } \\
2000 \\
M T\end{array}$ & $\begin{array}{c}\text { RAW } \\
\text { RESERVES } \\
\text { U.S. } \\
\text { MI }\end{array}$ & $\begin{array}{c}\text { RAW } \\
\text { RESOURCES } \\
\text { U.S. } \\
\text { MT }\end{array}$ \\
\hline $\begin{array}{l}\text { SILVER ORE } \\
\text { SODA ASH (NAT.) } \\
\text { SODIUM NITRATE } \\
\text { SOYBEAN } \\
\text { STONE } \\
\text { SULFUR ORE } \\
\text { TAKTALUM ORE } \\
\text { TIMBER, LUMBER } \\
\text { TIN ORE } \\
\text { TUNG NUTS } \\
\text { TUNGSTEN ORE } \\
\text { UATER, FRESH } \\
\text { HATER, SEAWATER } \\
\text { UHEAT } \\
\text { ZINC BYPROD. } \\
\text { ZINC BYPROD. } 2 \\
\text { ZINC BYPROD.\$3 } \\
\text { ZINC ORE }\end{array}$ & $\begin{array}{r}13.6 \mathrm{M} \\
4.85 \mathrm{M} \\
536 . \mathrm{K} \\
62 . \mathrm{M} \\
7 . \mathrm{G} \\
52.2 \mathrm{M} \\
310 . \mathrm{K} \\
1.4 \mathrm{G} \\
22.6 \mathrm{M} \\
105 . \mathrm{K} \\
5.09 \mathrm{M} \\
1.6 \mathrm{~T} \\
10 . \mathrm{T} \\
340 . \mathrm{M} \\
117 . \mathrm{M} \\
117 . \mathrm{M} \\
117 . \mathrm{M} \\
117 . \mathrm{M}\end{array}$ & $\begin{array}{r}37.3 \mathrm{M} \\
14 . \mathrm{M} \\
1.2 \mathrm{M} \\
120 . \mathrm{M} \\
13.4 \mathrm{G} \\
112 . \mathrm{M} \\
2.9 \mathrm{M} \\
1.9 \mathrm{G} \\
35.1 \mathrm{M} \\
1.15 \mathrm{G} \\
9.89 \mathrm{M} \\
2.86 \mathrm{~T} \\
11 . \mathrm{T} \\
710 . \mathrm{M} \\
224 . \mathrm{M} \\
224 . \mathrm{M} \\
224 . \mathrm{M} \\
224 . \mathrm{M}\end{array}$ & $\begin{array}{r}4.85 \\
60 . \\
110 . \\
180 . \\
2.63 \\
45.8 \\
125 . \\
140 . \\
421 . \\
880 . \\
24.4 \\
.16 \\
0 . \\
130 . \\
0 . \\
0 . \\
0 . \\
12.7\end{array}$ & $\begin{array}{r}271 . \mathrm{M} \\
31 . \mathrm{G} \\
1.0 \mathrm{E}+20 \\
1.0 \mathrm{E}+20 \\
1.0 \mathrm{E}+20 \\
1.73 \mathrm{G} \\
47.2 \mathrm{M} \\
1.0 \mathrm{E}+20 \\
1.02 \mathrm{G} \\
1.0 \mathrm{E}+20 \\
225 . \mathrm{M} \\
2.22 \mathrm{~T} \\
1.0 \mathrm{E}+20 \\
1.0 \mathrm{E}+20 \\
3.17 \mathrm{G} \\
3.17 \mathrm{G} \\
3.17 \mathrm{G} \\
3.17 \mathrm{G}\end{array}$ & $\begin{array}{r}1.01 \mathrm{G} \\
92 . \mathrm{G} \\
1.0 \mathrm{E}+20 \\
1.0 \mathrm{E}+20 \\
1.0 \mathrm{E}+20 \\
5.49 \mathrm{G} \\
209 . \mathrm{M} \\
1.0 \mathrm{E}+20 \\
3.76 \mathrm{G} \\
1.0 \mathrm{E}+20 \\
646 . \mathrm{M} \\
5.32 \mathrm{~T} \\
1.0 \mathrm{E}+20 \\
1.0 \mathrm{E}+20 \\
4.9 \mathrm{G} \\
4.9 \mathrm{G} \\
4.9 \mathrm{G} \\
4.9 \mathrm{G}\end{array}$ & $\begin{array}{r}14 \\
2.0 \\
16 \\
12 \\
3.0 \\
14 \\
39 \\
12 \\
28 \\
70 \\
21 \\
5.0 \\
0 \\
10 \\
20 \\
20 \\
20 \\
20\end{array}$ & $\begin{array}{r}52 \\
.40 \\
10 \\
25 \\
10 \\
33 \\
83 \\
20 \\
50 \\
35 \\
75 \\
20 \\
0 \\
25 \\
43 \\
43 \\
43 \\
43\end{array}$ & $\begin{array}{r}50 \\
0 \\
1.0 \\
0 \\
0 \\
0 \\
96 \\
18 \\
85 \\
80 \\
54 \\
0 \\
0 \\
0 \\
59 \\
59 \\
59 \\
59\end{array}$ & $\begin{array}{r}5.7 M \\
4.7 M \\
146 . K \\
31 . M \\
818 . M \\
10.9 M \\
482 . K \\
210 . M \\
5.18 M \\
13 . K \\
868 . K \\
437 . G \\
10 . T \\
23 . M \\
24.2 M \\
24.2 M \\
24.2 M \\
24.2 M\end{array}$ & $\begin{array}{r}10.2 \mathrm{M} \\
14.2 \mathrm{M} \\
326 . \mathrm{K} \\
80 . \mathrm{M} \\
2.27 \mathrm{G} \\
23.4 \mathrm{M} \\
1.6 \mathrm{M} \\
340 . \mathrm{M} \\
6.5 \mathrm{M} \\
20 . \mathrm{M} \\
2.8 \mathrm{M} \\
778 . \mathrm{G} \\
11 . \mathrm{T} \\
30 . \mathrm{M} \\
55.3 \mathrm{M} \\
55.3 \mathrm{M} \\
55.3 \mathrm{M} \\
55.3 \mathrm{M}\end{array}$ & $\begin{array}{r}67.1 M \\
30 . G \\
1.0 E+20 \\
1.0 E+20 \\
1.0 E+20 \\
20 B . M \\
. M \\
1.0 E+20 \\
4 . M \\
1.0 E+20 \\
15.6 M \\
606 . G \\
1.0 E+20 \\
1.0 E+20 \\
544 . M \\
544 . M \\
544 . M \\
544 . M\end{array}$ & $\begin{array}{r}253 . \mathrm{M} \\
46 . \mathrm{G} \\
1.0 \mathrm{E}+20 \\
1.0 \mathrm{E}+20 \\
1.0 \mathrm{E}+20 \\
640 . \mathrm{M} \\
1.23 \mathrm{M} \\
1.0 \mathrm{E}+20 \\
19.8 \mathrm{M} \\
1.0 \mathrm{E}+20 \\
54.3 \mathrm{M} \\
1.45 \mathrm{~T} \\
1.0 \mathrm{E}+20 \\
1.0 \mathrm{E}+20 \\
907 . \mathrm{M} \\
907 . \mathrm{M} \\
907 . \mathrm{M} \\
907 . \mathrm{M}\end{array}$ \\
\hline
\end{tabular}


TABLE A-3. ENGINEERING TO BULK CONVERSIONS

ENGINEERING MATERIAL : ALUMINUM BRONZE D

BULK MATERIALS

NAME
ALUMINUM
COPPER
STEEL \& IRON

PERCENT

7.00

91.00

2.00

ENGINEERING MATERIAL : ALUMINUM, 6061

BULK MATERIALS

NAME

PERCENT

ALUMINUM
COPPER
FERROCHROME
MAGNESIUM
SILICON (MET)

97.80

.25

.35

1.00

SILICON (MET) .60

ENGINEERING MATERIAL : ALUMINUM, 6063

BULK MATERIALS

$\quad$ NAME
ALUMINUM
MAGNESIUM
SILICON (MET)

PERCENT

.98 .90

7.00

4.00

ENGINEERING MATERIAL : ANTIMONY LEAD, 5\%

BULK MATERIALS

$$
\begin{aligned}
& \text { NAME } \\
& \text { ANT IMONY } \\
& \text { LEAD }
\end{aligned}
$$

ENGINEERING MATERIAL : ANTIMONY TIN SOLDER

BULK MATERIALS

NAME

ANT IMONY

TIN
PERCENT

5.00

95.00

ENGINEERING MATERIAL : ANTMONIAT, TEAD

BULK MATERIALS

NAME
ANT IMONY
LEAD

PERCENT

5.00

95.00

ENGINEERING MATERIAL : BRASS

BULK MATERIALS

NAME

COPPER

PERCENT

70.00

ZINC 
TABLE A-3. ENGINEERING TO BULK CONVERSIONS

(CONTINUED)

ENGINEERING MATERIAL : CALCIUM LEAD

BULK MATERIALS

LEAD
LIME

PERCENT

99.70

.30

ENGINEERING MATERIAL : CALCIUM LEAD, . $3 \%$

BULK MATERIALS

NAME

PERCENT

CALCIUM

LEAD

ENGINEERING MATERIAL : CARBON STEEL

BULK MATERIALS

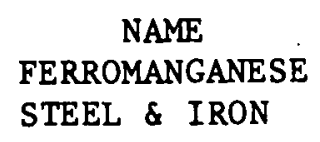

PERCENT

.60

99.40

ENGINEERING MATERIAL : CARBON-CARBON

BULK MATERIALS

NAME

GRAPHITE FIBER, SYNTHETIC

PERCENT

176.00

ENGINEERING MATERIAL : CAST IRON

BULK MATERIALS

NAME

FE RROMANGANESE

SILICON (MET)

STEEL \& IRON

PERCENT

.80

2.50

96.70

ENGINEERING MATERIAL.: CONCRETE

BULK MATERIALS

NAME

PERCENT

14.00

CEMENT

SAND \& GRAVEL

29.00

STONE, CRUSHED \& SIZED

57.00

ENGINEERING MATERIAL : COPPER NICKEL $10 \%$

BULK MATERIALS

NAME

COPPER

NICKEL

STEEL \& IRON

PERCENT

88.70

10.00

1.30

ENGINEERING MATERIAL : EPOXY GLASS LAM

BULK MATERIALS

NAME

PEKCENT

35.00

EPOXY RESIN

65.00 
TABLE A-3. ENGINEERING TO BULK CONVERSIONS

(CONTINUED)

ENGINEERING MATERIAL : FLAT BLACK ALKYD PAINT

BULK MATERIALS

$$
\begin{aligned}
& \text { NAME } \\
& \text { ALKYD RESIN } \\
& \text { CARBON BLACK } \\
& \text { PAINT THINNER }
\end{aligned}
$$

PERCENT

13.00

62.00

25.00

ENGINEERING MATERIAL : FRP POLYESTER

BULK MATERIALS

NAME

GIASS, FIBER

POLYESTER RESIN

PERCENT

30.00

70.00

ENGINEERING MATERIAL : FRP POLYESTER

BULK MATERIALS

\begin{tabular}{l}
\multicolumn{1}{c}{ NAME } \\
GLASS, FIBER \\
POLYESTER RESIN
\end{tabular}

PERCENT

47.00

53.00

ENGINEERING MATERIAL : GFRTP

BULK MATERIALS

NAME

GRAPHITE FIBER, SYNTHETIC

POLYSULFONE
PERCENT
60.00
40.00

ENGINEERING MATERIAL : LEADED RED BRASS

BULK MATERIALS

NAME
COPPER
LEAD
TIN
ZINC

PERCENT

85.00

5.00

5.00

5.00

ENGINEERING MATERIAL : LEADED TIN BRONZE

BULK MATERIALS

NAME
COPPER
LEAD
TIN
ZINC

PERCENT
88.00
2.00
6.00
5.00

ENGINEERING MATERIAL : MASONITE

BULK MATERIALS

NAME

COTTON FIBERS

KRAFT FIBERS

PHENOLIC RESIN
PERCENT

35.00

15.00

50.00 
TABLE A-3. ENGINEERING TO BULK CONVERSIONS (CONTINUED)

ENGINEERING MATERIAL : MICARTA

BULK MATERIALS

- BULK MATERIALS

BULLK MATERIALS

ENGINEERING MATERIAL : PLYWOOD

LUMBER ,SOFTWOOD
$/$ /*ONAME * /

CHROMIUM

NICKEL

SILICON (MET)

ENGINEERING MATERIAL : NICHROME

KRAFT FIBERS
PERCENT

35.00

15.00

50.00

PERCENT

20.00

78.00

2.00

PERCENT

98.00

2.00 .

ENGINEERING MATERIAL : $\mathrm{R}-22$

BULK MATERIALS

TEFLON

PERCENT 100.00

ENGINEERING MATERIAL : SILICA TILE

BULK MATERIALS

NAME

PERCENT

SILICA FIBER

900.00

ENGINEERING MATERIAL : SILICON STEEL

BULK MATERIALS

NAME

SILICON (MET)

STEEL \& IRON

PERCENT

3.00

97.00

ENGINEERING MATERIAL : SOLDER, 50-50

BULK MATERIALS

NAME

LEAD

PERCENT

50.00

TIN

50.00 
TABLE A-3. ENGINEERING TO BULK CONVERSIONS (CONTINUED)

ENGIṆEERING MATERIAL : SOLDER, 60-40

- BULK MATERIALS

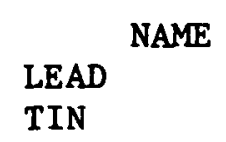

PERCENT

37.00

63.00

ENGINEERING MATERIAL : STAINLESS STEEL, 304

BULK MATERIALS

NAME
CHROMIUM
NICKEL
STEEL \& IRON

PERCENT

27.00

10.00

63.00

ENGINEERING MATERIAL : STAINLESS STEEL, 316

BULK MATERIALS

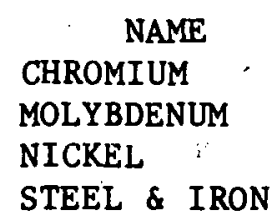

PERCENT

24.00

3.00

12.00

61.00

ENGINEERING MATERIAL : STAINLESS STEEL, 416

BULK MATE RIALS

$\quad$ NAME
CHKUMIUM
STEEL \& IRON
SULFIR

PERCENT

19.00

81.00

2.00

ENGINEERING MATERIAL : TIN BRONZE

BULK MATERIALS

NAME
COPPER
TIN

PERCENT

89.00

11.00

ENGINEERING MATERIAL : TRANSITE

BULLK MATERTALS

NAME

ASBESTOS

CEMENT

PERCENT

25.00

75.00

ENGINEERING MATERIAL : VARNISH

BULK MATERIALS

NAME

ALKYD RESIN

LINSEED OIL

TUNG OIL
J

PERCENT

100.00

50.00

150.00 
TABLE A-4. BULK MATERIAL PRODUCTION PROCESSES

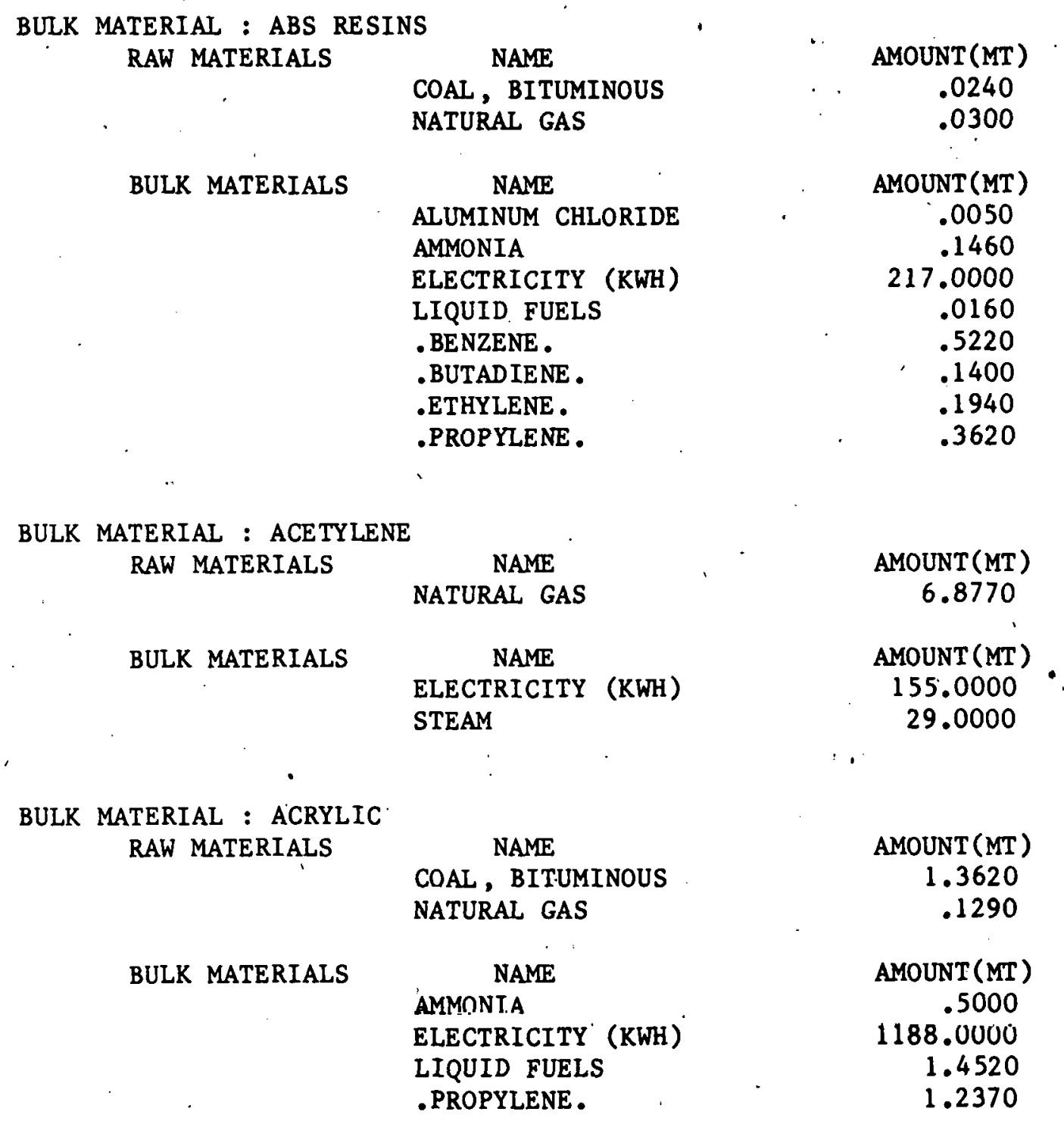

BULK MATERIAL : ALKYD RESIN

\begin{tabular}{ll} 
BULK MATERIALS & \multicolumn{1}{c}{ NAME } \\
& CAUSTIC SODA \\
& ELECTRICITY (KWH) \\
& METHANOL \\
& OXYGEN, GASEOUS \\
& STEAM \\
& .ETHYLENE. \\
& O-XYLENE. \\
& (MISC. BULK MATERIALS)
\end{tabular}
AMOUNT(MT) .1940
72.0000 .2020 .4140 .6150 .0950 .7600 .2220


TABLE A-4. BULK MATERIAL PRODUCTION PROCESSES

(CONTINUED)

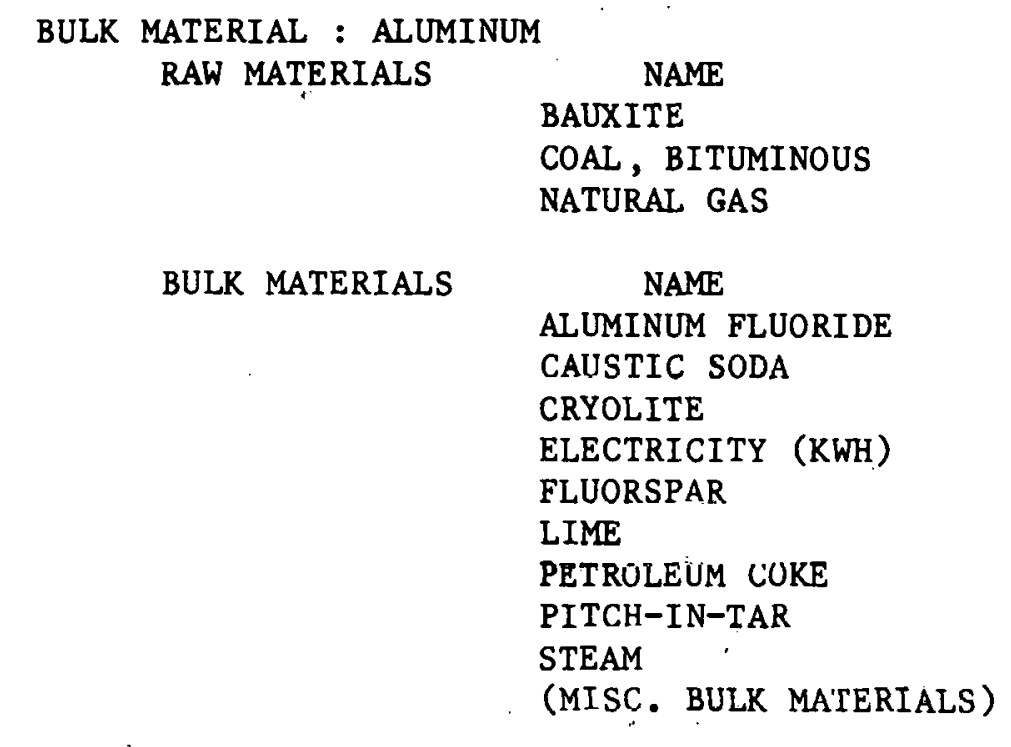

$$
\begin{gathered}
\text { AMOUNT(MT) } \\
4.7000 \\
.0200 \\
.2576 \\
\\
\text { AMOUNT(MT) } \\
.0200 \\
.1500 \\
.0350 \\
17940.0000 \\
.0030 \\
.1000 \\
.4250 \\
.3000 \\
9.8720 \\
.0050
\end{gathered}
$$

BULK MATERIAL : ALUMINUM OXIDE

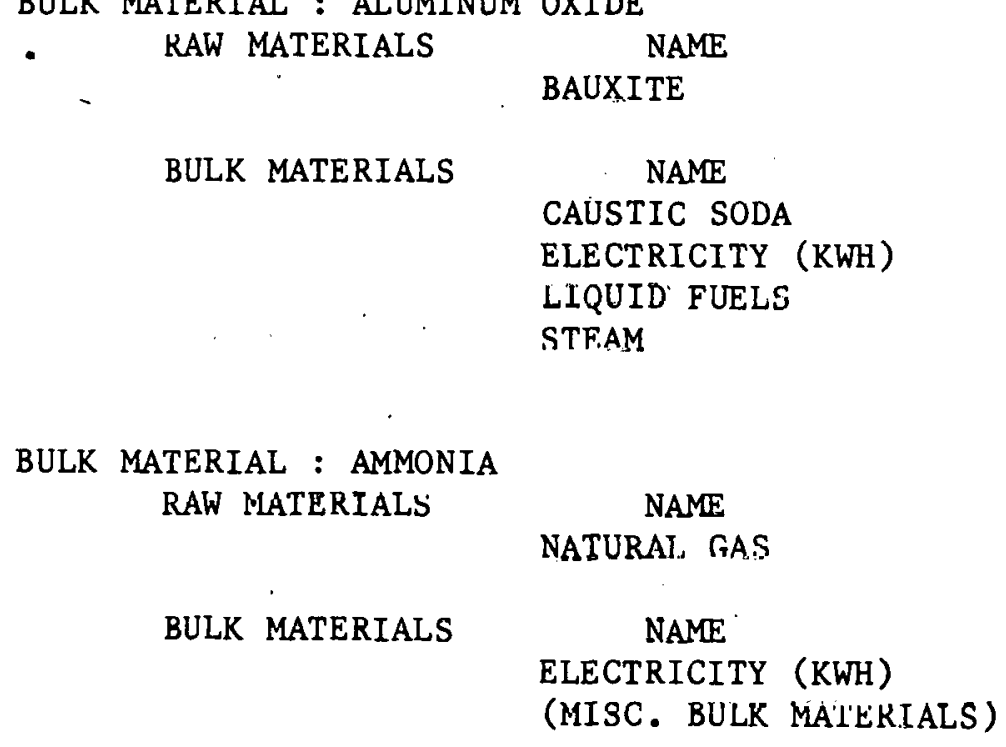


TABLE A-4. BULK MATERIAL PRODUCTION PROCESSES (CONTINUED)

BULX MATERIAL : ANTIMONY RAW MATERIALS

\begin{tabular}{l}
\multicolumn{1}{c}{ NAME } \\
ANTIMONY ORE \\
IRON ORE \\
LIMESTONE \\
NATURAL GAS \\
SAND \& GRAVEL
\end{tabular}

BULK MATERIALS
NAME

CAUSTIC SODA

COKE

ELECTRICITY (KWH)

ELECTRODES

LIQUID FUELS

SODIUM CARBONATE

STEEL \& IRON

(MISC. BULK MATERIALS)
AMOUNT(MT)

105.0000

.0800

1.2300

.1522

.3200

AMOUNT (MT)

3.3400

.5600

170.0600

.0020

.0070

.0260

.0070

.0120

AMOUNT(MT)

.8400

AMOUNT(MT)

428.0000

.0015
NAME

ELECTRICITY (KWH)

HYDROGEN

BULK MATERIAL : ARSENIC

RAW MATERIALS

BULK MATERIALS

$$
\begin{gathered}
\text { NAME } \\
\text { COAL, BITUMINOUS } \\
\text { NAME } \\
\text { ARSENIC TRIOXIDE }
\end{gathered}
$$

AMOUNT (MT) .3400

AMOUNT (MT)

1.4000

BULK MATERIAL : AREENIC TRIOXIDE RAW MATERIALS

NAME COPPER BYPROD. NATURAL GAS

BULK MATERIALS
NAME ELECTRICITY (KWH)
AMOUNT (MT)

2.3000

.1170

AMOUNT (MT)

121.0000 
TABLE A-4. BULK MATERIAL PRODUCTION PROCESSES (CONTINUED)

BULK MATERIAL : ARSINE, $99.999 \%$

BULK MATERIALS

NAME

SULFURIC ACID

AMOUNT (MT)

2.1400

ZINC ARSENIDE

2.4700

BULK MATERIAL : BORON OXIDE

RAW MATERIALS

NAME

BORON 'OXIDE

AMOUNT (MT)

1.0000

BULK MATERIAL : BORON TRIFLUORIDE ETHERAT

BULK MATERIALS : NAME

BORAX

DIETHYL ETHER

HYDROFLUORIC ACID

SULFURIC ACID

AMOUNT (MT)

.6700

.5200

.4300

.3500

BULK MATERIAL : BORON, 99.9995\%

BULK MATERIALS

NAME

BORON OXIDE

AMOUNT(MT)

5.3500

CIILORINE

ELECTRICITY (KWH)

14.7000

ELECTRODES

HYDROGEN

PETROLEUM COKE

1100000.0000

4.2000

.3730

3.2100

BULK MATERIAL : BROMINE

RAW MATERIALS

NAME
WATER, SEAWATER
$\quad$ NAME
CHLORINE
ELECTRICITY (KWH)
STEAM

AMOUNT (MT)

1000.0000

BULK MATERIALS
AMOUNT (MI')
.5000
153.0000
.5600


TABLE A-4. BULK MATERIAL PRODUCTION PROCESSES (CONTINUED)

BULK MATERIAL : CADMIUM

RAW MATERIALS

BULK MATERIALS

$$
\begin{array}{r}
\text { AMOUNT(MT) } \\
.0370 \\
400.0000 \\
\text { AMOUNT(MT) } \\
.0630 \\
221.0000 \\
.0150 \\
8.2000 \\
1.0200
\end{array}
$$

AMOUंNT (MT)

.8000

.2300

SULFUR

BULK MATERIAL : CALCIUM

RAW MATERIALS

NAME

NATURAL GAS

AMOUNT (MT)

1.9500

BULK MATERIALS

$\quad$ NAME
ELECTRICITY (KWH)
FERROSILICON
LIME

AMOUNT (MT)

25.0000

1.4000 .

1.5600

AMOUNT (MT)

5.1710
AMOUNT(MT)

1.5000

AMOUNT:(MT)

2750.0000

.0250

10.0000

.1000 
TABLE A-4. BULK MATERIAL PRODUCTION PROCESSES (CONTINUED)

BULK MATERIAL : CEMENT RAW MATERIALS

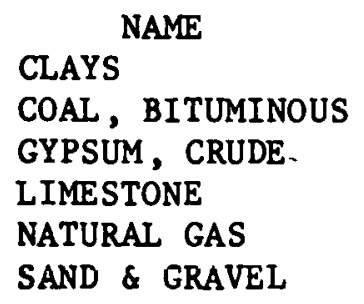

AMOUNT (MT) .1440 .0908 .0480 1.3700 .0700 .0570

BULK MATERIALS

NAME
ELECTRICITY (KWH)
LIQUID FUELS
SIEEL \& IRON

AMOUNT (MT)

131.0000

.0240

.0010

BULK MATERIAL : CESIUM

BULK MATERIAL : CHLORINE RAW MATERIALS NAME

AMOUNT (MT) SALT 1.8300

BULK MATERIALS

$\quad$ NAME
ELECTRICITY (KWH)
ELECTRODES
SODIUM CARBONATE
STEAM
SULFURIC ACID

AMOUNT (MT)

3310.0000 .0005 .0029

11.4250 .0010

BULK MATERIAL : CHLOROFORM

RAW MATERIALS

BULK MATERIALS

AMOUNT (MT) .1750

AMOUNT(MT) 1.7800

BULK MATERIAL : COKE

RAW MATERIALS

NÁTURAL GAS

NAME

GHLORINE

AMOUNT(MT)

COAL, BITUMINOUS

1.4500

BULK MATERIALS

NAME
ELECTRICITY (KWH)
STEAM
(MISC. BULK MATERIALS)

AMOUNT (MT)

36.4000

.5000 .0010 
TABLE A-4. BULK MATERIAL PRODUCTION PROCESSES. (CONTINUED)

BULK MATERIAL : COPPER

RAW MATERIALS

$\quad$ NAME
COAL, BITUMINOUS
COPPER ORE
NATURAL GAS

AMOUNT (MT) .0033

142.8600

.6670

BULK MATERIALS

NAME

ELECTRICITY (KWH)

LIQUID FUELS

STEAM

STEEL \& IRON

SULFURIC ACID

(MISC. BULK MATERIALS)

AMOUNT(MT)

5000.0000

.4790

.1835

.3865

.0165

.3620

BULK MATERIAL : CUPROUS CHLORIDE

BULK MATERIALS

NAME

CHLORINE

COPPER

AMOUNT (MT)

.3600

.6500

BULK MATERIAL : DIBORANE

BULK MATERIALS

- NAME

BORON TRIFLUORIDE ETHERAT

SODIUM BOROHYDRIDE

AMOUNT(MT)

8.8000

2.3000

BULK MATERIAL : DIMETHYL ALUM. CHLORIDE

BULK MATERIALS

$$
\begin{aligned}
& \text { ALUMINUM } \\
& \text { METHYL CHLORIDE }
\end{aligned}
$$
AMOUNT (MT) .6000
1.6700

4

BULLK. MATF.RTAI. : ELFC.TRISITY (KWH)

RAW MATERIALS

NAME

COAL, BITUMINOUS

AMOUNT (MT) 
TABLE A-4. BULK MATERIAL PRODUCTION PROCESSES

(CONTINUED)

BULK MATERIAL : ELECTRODES

RAW MATERIALS

NAME:

NATURAL GAS

AMOUNT (MT)

.6720

BULK MATERIALS

NAME

AMOUNT(MT)

ELECTRICITY (KWH)

7750.0000

PETROLEUM COKE

1.5000

PITCH-IN-TAR

.5000

BULK MATERIAL : EPOXY RESIN

RAW MATERIALE

NAME
COAL, BITUMINOUS
NATURAL GAS

AMUUN'I'(MT)

.0330

.0410

BULK MATERIALS

NAME .

CAUSTIC SODA

CHLORINE

ELECTRICITY (KWH)

LIQUID FUELS

.BENZENE.

. PROPYLENE.

AMOUNT (MT)

.6650

1.2390

300.0000

.0220

.7240

.7880

BULK MATERIAL : ETHYLENE GLYCOL

BULK MATERIALS

NAME
.ETHYLENE.

AMOUNT(MT)

.9000

BULK MATERIAL : ETHYLENE PROPYLENE

RAW MATERIALS

NAME

NATURAL GAS

AMOUNT (MT)

.8140

BULK MATERIALS

NAME

DUYCLOPINTADIENF.

AMOUNT (MT)

.0530

ELECTRICITY (KWH)

SULFURIC ACID

-ETHYLENE.

-PROPYLENE.

(MISC. BULK MATERIALS)

653.0000

.0370

.6460

.4550

.0870

BULK :

BULK MATERIAL : ẼVA

BULK MATERIALS

$\quad$ NAME
ELECTRICITY (KWH)
STEAM
.ETHYLENE.

AMOUNT(MT)

35.0000

.2640

1.0270 
TABLE A-4. BULK MATERIAL PRODUCTION PROCESSES

(CONTINUED)

BULK MATERIAL : FERROCHROME RAW MATERIALS

NAME

AMOUNT (MT)

CHROMITE

SILICA PEBBLE

2.5000

.2130

BULK MATERIALS

NAME

AMOUNT (MT)

COKE

ELECTRODES

(MISC. BULK MATERIALS)

.3750

.0220

.1210

BULK MATERIAL : FERROMANGANESE

RAW MATERIALS

NAME

LIMESTONE

MANGANESE ORE

AMOUNT.(MT)

.3000

2.2000

BULK MATERIALS

NAME ,

COKE

ELECTRICITY (KWH)

FERROUS SCRAP, PURCHASED

(MISC. BULK MATERIALS)

AMOUNT(MT)

.5000

3064.0000

.1500

.2190

BULK MATERIAL : FERROSILICON

RAW MATERIALS

NAME

NATURAL GAS

SILICA PEBBLE

AMOUNT(MT)

.0640

1.1500

BULK MATERIALS

NAME

COAL, BITUMINOUS

COKE

ELECTRICITY (KWIH)

FERROUS SCRAP, PURCHASED

PETROLEUM COKE

PITCH-IN-TAR

(MISC. BULK MATERIALS)

AMOUNT (MT)

.5500

.0900

5934.0000

. .5500

.0300

.0070

.1380

BULK MATERIAL : FLUORINE

\begin{tabular}{ll} 
RAW MATERIALS & \multicolumn{1}{c}{ NAME } \\
& NATURAL GAS \\
BULK MATERIALS & \multicolumn{1}{c}{ NAME } \\
& ELECTRICITY (KWH) \\
& FLUORSPAR \\
& STEAM \\
& SULFURIC ACID
\end{tabular}

AMOUNT (MT)

.2440

AMOUNT (MT)

3738.0000

2.5000

1.9500

3.1700 
TABLE A-4. BULK MATERIAL PRODUCTION PROCESSES (CONTINUED)

BULK MATERIAL : FLUORSPAR

RAW MATERIALS

NAME

FLUORSPAR ORE

AMOUNT(MT)

NATURAL GAS

3.0400

.0400

BULK MATERIALS

NAME
ELECTRTCITY (KWH)
LIQUID FUELS
STEEL \& IRON
(MISC . DULK MATERIALS)

AMOUNT(MT)

297.0000 .0044 .0032 .0300

BULK MATERIAL : GALLIUM

RAW MATERIALS

NAME
BAUXITE, BY PROD

AMOUNT (MT)

50000.0000

BULK MATERIALS

NAME

CARBON DIOXIDE

CAUSTIC S SODA

ELECTRICITY (KWH)

HYDROCHLORIC ACID

NITRIC ACID

STEAM

$$
\begin{array}{r}
\text { AMOUNT(MT) } \\
242.3000 \\
9.1000 \\
151170.0000 \\
.1000 \\
.0800 \\
.0820
\end{array}
$$

BULK MATERIAL : GALLIUM ARSENIDE (DEP)

BULK MATERIALS

NAME

AMOUNT(MT)

.5770

ARSENIC

.5430

BULK MATERIAL : GALLIUM ARSTENIDE (TNCSOT)

BULK MATERIALS

NAME

AMOUNT (MT) .5770

ARSENIC

ELECTRICITY (KWH)

GALLIUM

200000.0000

.5430

BULK MATERIAL : GALLIUM ARSENIDE (WAFER)

BULK MATERIALS

NAME

AMOUNT(MT)

GALLIUM ARSENIDE (INGOT)

2.2200 
TABLE A-4. BULK MATERIAL PRODUCTION PROCESSES

(CONTINUED)

BULK MATERIAL : GALLIUM TRICHLORIDE

BULK MATERIALS

NAME

AMOUNT(MT)

CHLORINE

GALLIUM

.6400

.4200

BULK MATERIAL : GERMANE, $99.9 \%$

RAW MATERIALS

$$
\text { WATER, FRESH }
$$

BULK MATERIALS

NAME
GERMANIUM TETRACHLORIDE
SODIUM BOROHYDRIDE

BULK MATERIAL : GERMANIUM RAW MATERIALS

$$
\begin{aligned}
& \text { NAME } \\
& \text { PROPANE } \\
& \text { ZINC ORE. }
\end{aligned}
$$

BULK MATERIALS

NAME
CAUSTIC SODA
CHLORINE
ELECTRICITY (KWH)
HYDROCHLORIC ACID
HYDROGEN

AMOUNT(MT)

3.5700

AMOUNT (MT)

3.5400

2.5000

AMOUNT (MT)

$1.670,0$

2500000.0000

AMOUNT (MT)

.0500

.6600

185808.0000

32.8000

.0870

BULK MATERIAL : GERMANIUM TETRAĊHLORIDE

BULK MATERIALS

$$
\begin{aligned}
& \text { CHLORINE } \\
& \text { GERMANIUM }
\end{aligned}
$$

$$
\begin{gathered}
\text { AMOUNT (MT) } \\
.7000 \\
.3600
\end{gathered}
$$

BULK MATERIAL : GLASS, BOROSILIC RAW MATERIALS

NAME

NATURAL GAS

SAND \& GRAVEL

. SODA ASH (NA'..)

BULK MATERIALS
NAME ALUMINUM OXIDE BORON OXIDE ELECTRICITY (KWH) LIQUID FUELS (MISC. BULK MATERIALS)
AMOUNT (MT)

.1700

.8530

.0900

AMOUNT(MT)

.0210

.1270

330.0000

.0430

.0152 
TABLE A-4. BULK MATERIAL PRODUCTION PROCESSES (CONTINUED)

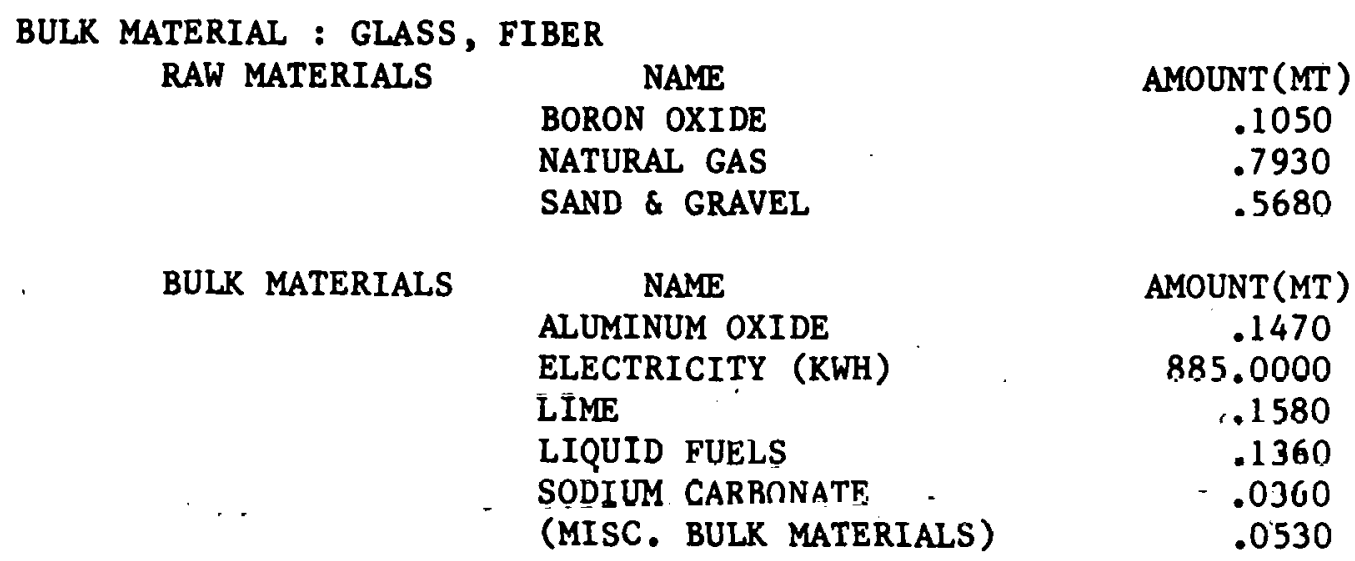

BULK MATERIAL : GLASS, SODA LIME RAW MATERIALS

NAME

FELDSPAR

AMOUNT(MT) .0922

LIME STONE

NATURAL GAS

SAND \& GRAVEL

SODA ASH (NAT.)

.1999

.1700

.6510

.0867

BULK MATERIALS

NAME

ELECTRICITY (KWH)

LIQUID FUELS

SODIUM CARBONATE

(MTSC. BULK MATERIALS)

AMOUNT (MT)

$3.30,0000$

.0430

.1300

.0152

BULK MATERIAL : GOLD

RAW MATERIALS

NAME
GOLD ORE
SODA ASH (NAT.)

BULK MATERIALS

NAME

CHLORINE

ELECTRICITY (KWH)

LIME

LIQUID FUELS

STEAM

STEEL \& IRON

SULFURIC ACID

ZINC

(MISC. BULK MATERIALS)

$$
\begin{array}{r}
\text { AMOUNT(MT) } \\
116280.0000 \\
32.3000 \\
\\
\text { AMOUNT(MT) } \\
202.0000 \\
3000000.0000 \\
525.0000 \\
727.0000 \\
60.9000 \\
54.7000 \\
9.4000 \\
11.0000 \\
205.9000
\end{array}
$$

BULK MATERIAL : GRAPHITE FIBER, SYNTHETIC 


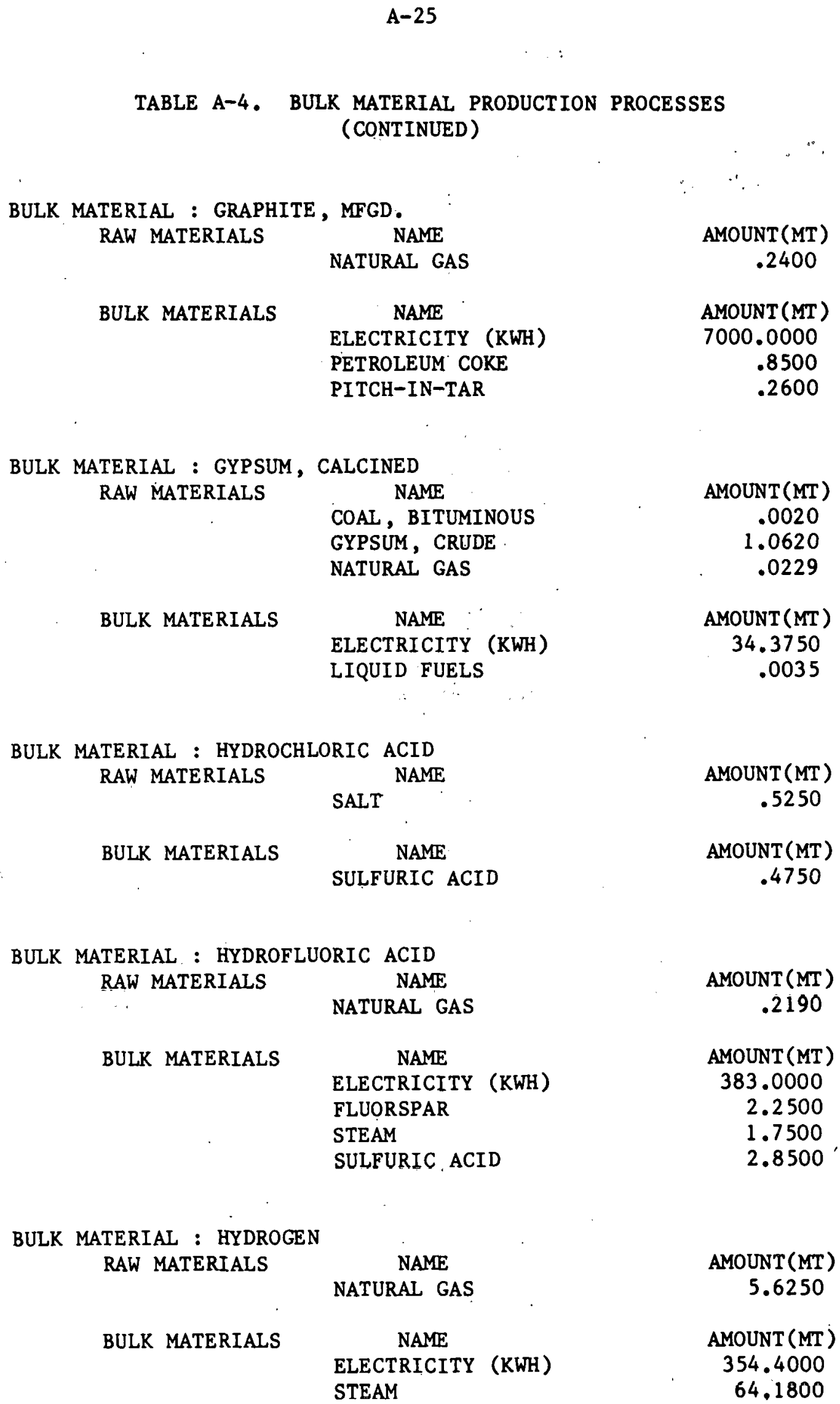

BULK MATERIAL : HYDROFLUORIC ACID

RAW MATERIALS

NAME

NATURAL GAS

BULK MATERIALS

\begin{tabular}{l}
\multicolumn{1}{c}{ NAME } \\
ELECTRICITY (KWH) \\
FLUORSPAR \\
STEAM \\
SULFURIC, ACID
\end{tabular}

BULK MATERIAL : HYDROGEN RAW MATERIALS

NAME NATURAL GAS

AMOUNT(MT)

5.6250

BULK MATERIALS

$$
\begin{gathered}
\text { AMOUNT(MT) } \\
.2190 \\
\text { AMOUNT(MT) } \\
383.0000 \\
2.2500 \\
1.7500 \\
2.8500
\end{gathered}
$$

AMOUNT (MT)

354.4000

64.1800 
$\therefore$ TABLE A-4: BULK MATERIAL PRODUCTION PROCESSES (CONTINUED).

BULK MATERIAL : HYDROGEN SULFIDE, 99.999\%

BULK MATERIALS NAME

STEEL \& IRON

SULFUR

SULFURIC ACID

AMOUNT(MT)

1.6400

1.8800

5.8000

BULK MATERIAL : INDIUM

RAW MATERIALS

NAME

NATURAL GAS

SALT

ZINC BYPROD.

BULK MATERIALS

NAME

ALUMINUM

AMMONI $\Lambda$

ELECTRICITY (KWH)

SULFURIC ACID

$$
\begin{array}{r}
\text { AMOUNT(MT) } \\
9.9500 \\
1.8400 \\
4000.0000 \\
\text { AMOUNT(MT) } \\
.2600 \\
.6500 \\
2087.0000 \\
21.2600
\end{array}
$$

BULK MATERIAL : INDIUM TRICHLORIDE

BULK MATERIALS . NÄME

AMOUNT (MT)

CHLORINE

.3100

INDIUM

.5500

BULK MATERIAL : INDIUM-TIN OXIDE.

BULK MATERIALS

$$
\begin{aligned}
& \quad \text { NAME } \\
& \text { INDIUM } \\
& \text { NITRIS. ACID } \\
& \text { TIN }
\end{aligned}
$$

BULK MATERLAL : KAPTON

RAW MATERIALS

BULK MATERIALS
NAME

PETROLEUM

NAME

CHLORINE

HYDROGEN

NITRIC ACID

SULFURIC ACID

-BENZENE.
AMOUNT(MT)
.8000
1.4000
.0430

AMOUNT (MT)

44.6250

AMOUNT (MT)

1.2290

.0470

1.0630

1.4460

1.7110 
TABLE A-4. BULK MATERIAL PRODUCTION PROCESSES

(CONTINUED)

BULK MATERIAL : LEAD

RAW MATERIALS

BULK MATERIÁLS

$\quad$ NAME
IRON ORE
LEAD ORE
LIMESTONE
NATURAL GAS
SAND \& GRAVEL
SULFUR ORE

AMOUNT(MT)

$$
.0700
$$

21.0000

.1200

.1610

.0900

.0020

AMOUNT (MT)

.0010

.0010

.2550

1003.0000

.0220

.0020

.0100

.0190

.0120

BULK MATERIAL : LIME

RAW 'MATERIALS

NAME
COAL, BITUMINOUS
LIMESTONE
NATURAL GAS
NAME
ELECTRICITY (KWH)
LIQUID FUELS
(MISC. BULK MATERIALS)

AMOUNT (MT)

.1557

2.8800

.0790

BULK MATERIALS
ELECTRICITY (KWH)
LIQUID FUELS
(MISC.
AMOUNT (MT)
63.2800
.0160
.0005

BULK MATERIAL : LIQUID FUELS

RAW MATERIALS

AMOUNT(MT)

PETROLEUM

1.0570 
TABLE A-4. BULK MATERIAL PRODUCTION PROCESSES (CONTINUED)

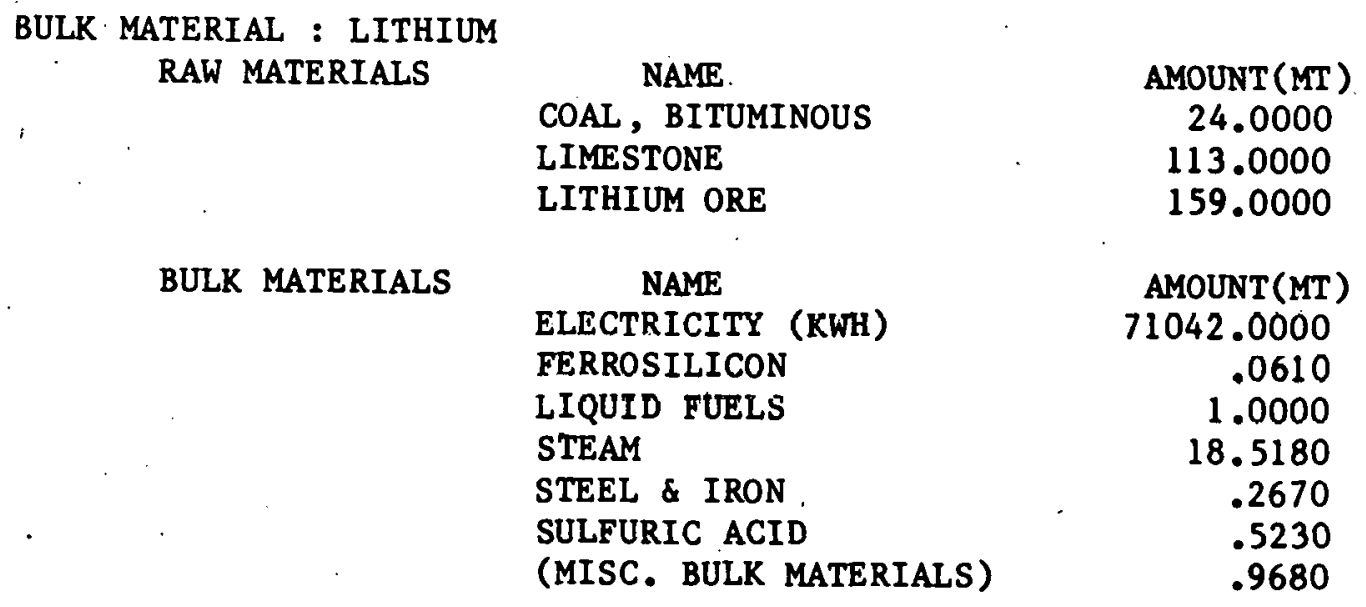

NAME.

COAL, BITUMINOUS

LIMESTONE

LITHIUM ORE

BULK MATERIALS

NAME

ELECTRICITY (KWH)

FERROSILICON

LIQUID FUELS

STEAM

STEEL \& IRON .

SULFURIC ACID

(MISC. BULK MATERIALS)

$$
\begin{array}{r}
\text { AMOUNT(MT) } \\
24.0000 \\
113.0000 \\
159.0000 \\
\\
\text { AMOUNT(MT) } \\
11042.0000 \\
.0610 \\
1.0000 \\
18.5180 \\
.2670 \\
.5230 \\
.9680
\end{array}
$$

71042.0000

BULK MATERIAL : LITHIUM HYDRIDE

$\begin{array}{ll}\text { BULK MATERIALS } & \text { NAME } \\ & \text { HYDROGEN } \\ & \text { LITHIUM }\end{array}$

AMOUNT(MT)

.1300

.9200

BULK MATERIAL : MAGNESIUM

\begin{tabular}{ll} 
RAW MATERIALS & \multicolumn{1}{c}{ NAME } \\
& LIMESTONE \\
& NATURAL GAS \\
& WATER, SEAWATER \\
BULK MATERIÁLS & \multicolumn{1}{c}{ NAME } \\
& CHLORINE \\
& ELECTRICITY (KWH) \\
& ELECIRODES \\
& LIOIIID FITISS \\
& (MISC. BULK MATERIALS)
\end{tabular}

AMOUNT(MT)

7.6000

3.4240

.721 .0000

AMOUNT(MT)

.4900

19076.0000

.1004

.0062

.0022

BULK MATERIAL : MERCUKY

RAW MATERIALS

NAME

MERCURY ORE

AMOUNT (MT) .

34.4800

BULK MATERIALS

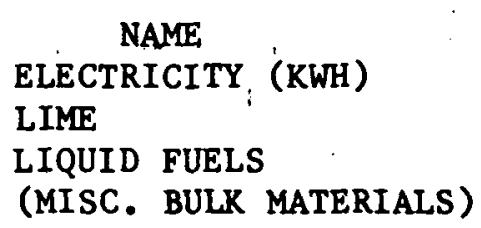

AMOUNT(MT)

18630.0000

.0900

4.9400

.0750 


$$
\begin{aligned}
& 0 I 59^{\circ} \\
& 0 \angle 57^{\circ} \\
& \text { (IW) INNOWV }
\end{aligned}
$$

$0000^{\circ} \tau$

(IW) INNOWH

\author{
NOLdWX \\ बIJY วI\&OTHวOУवXH \\ IWVN STVIYGIVW XINA

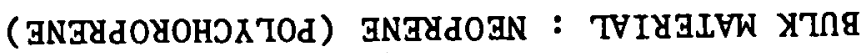
SHS THYOLFN JWVN S STVIYGIVW MVY

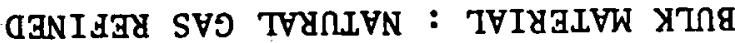

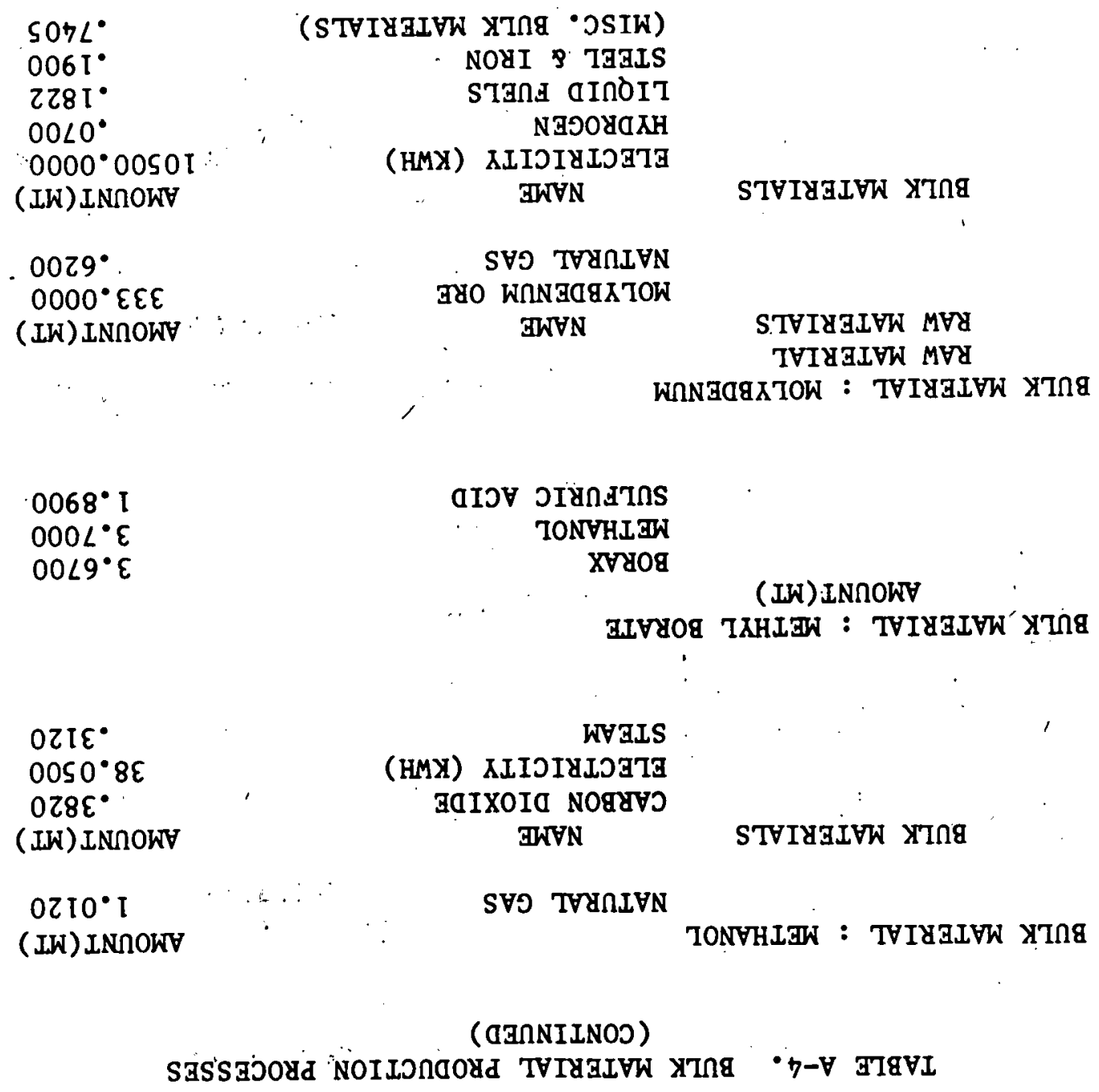


TABLE A-4. BULK MATERIAL PRODUCTION PROCESSES (CONTINUED)

BULK MATERIAL : NICKEL

RAW MATERIALS

BULK MATERIALS

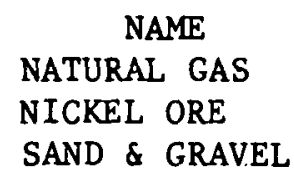

$\quad$ NAME
CHLORINE
COKE
ELECTRICITY (KWH)
ELECTRODES
LIME
LIQUID FUELS
OXYGEN, GASEOUS
SODIUM CARBONATE
STEEL \& IRON
(MISC. BULK MATERIALS)

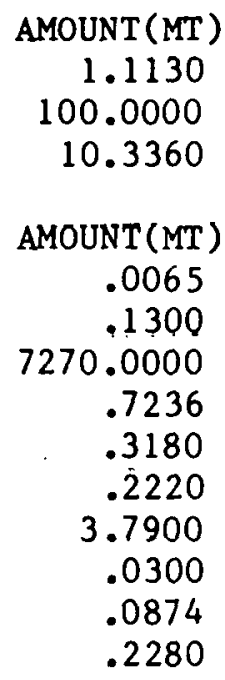

AMOUNT(MT) .2900 385.0000

BULK MATERIAL : NITRIC ACID

BULK - MATERIALS

i

BULK MATERIAL ; NYLON RESINS

RAW MATERIALS

COAL, BITUMINOUS

NATURAL GAS

BULLK MATERIALS

AMMONIA

ELECTRICITY (KWH)

HYDROGEN

LIQUID FIJFISS

NITRIC ACID

.BENZENE.

(MISC. BULK MATERIALS)

AMOUNT (MT)

.0740

.0340

AMOUNT (MT)

.2070

533.0000

.1580

.1070

1.4540

1.0880

.0011

BULK MATERIAL : ORTHO-PHOSPHOROUS ACID

RAW MATERIALS

NAME

WATER, FRESH

AMOUNT (MT) .6600

BULK MATERIALS

NAME

PHOSPHOROUS TRICHLORIDE

AMOUNT (MT)

1.6800 
TABLE A-4. BULK MATERIAL PRODUCTION PROCESSES (CONTINUED)

BULK MATERIAL : OXYGEN, GASEOUS

BULK MATERIALS

$$
\begin{aligned}
& \text { NAME } \\
& \text { ELECTRICITY (KWH) }
\end{aligned}
$$

AMOUNT(MT)

244.0000

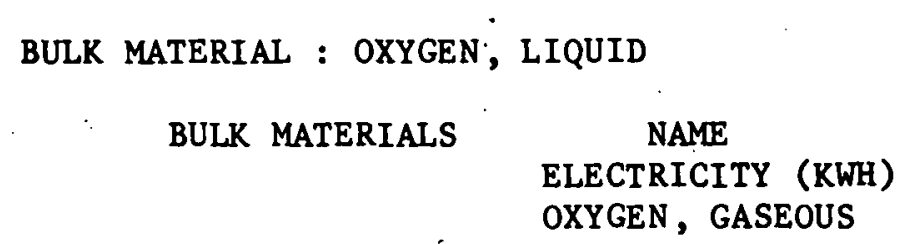
AMOUNT(MT)
937.0000
1.0000

BULK MATERIAL : PALLADIUM

RAW MATERIALS

NAME

CU ANODE SLIMES

AMOUNT(MT)

476190.0000

BULK MATERIALS

NAME

AMMONIA'

ELECTRICITY (KWH)

HYDROCHLORIC ACID
AMOUNT (MT)
.6400
25.0000
1.3740
AMOUNT(MT)
51.7000

BULK MATERIAL : PETROLEUM COKE

RAW MATERIALS

NAME

PETROLEUM

BULK MATERIAL : PHENOLIC RESIN

RAW MATERIALS

NAME

COAL, BITUMINOUS

NATURAL GAS

AMOUNT (MT)

.1540

.0720

BULK MATERIALS

NAME

CARBON MONOXIDE

ELECTRICITY (KWH)

HYDROGEN

LIQUID FUELS

STEAM

-BENZENE.

.PROPYLE NE .

AMOUNT (MT)

.6010

798.0000

.0860

.0380

3.4500

.8060

.4330

BULK MATERIAL : PHOSPHINE 99.999\%

BULK MATERIALS

NAME
ORTIO-PHOSPHOROUS ACID

AMOUNT (MT)

10.0000 
TABLE A-4. BULK MATERIAL PRODUCTION PROCESSES (CONTINUED)

BULK MATERIAL : PHOSPHOROUS

RAW MATERIALS

NAME

NATURAL GAS

PHOSPHATE ROCK

SAND \& GRAVEL

BULK MATERIALS

COKE NAME
ELECTRICITY (KWH)
ELECTRODES

AMOUNT (MT) .0470

10.3000

1.3600

AMOUNT(MT)

1.6000

15216.0000

.0200

BULK MATERIAL : PHOSPHOROUS TRICHLORIDE

BULK MATERIALS NAME

CHLORINE

PHOSPHOROUS
AMOUNT (MT)

.7800

.2300

AMOUNT (MT)

51.6000

BULK MATERIAL : PITCH-IN-TAR

RAW MATERIALS

$$
\text { COAL, BITUMINOUS }
$$
BULK MATERIAL : POLYACRYLONITE FIBER
RAW MATERIALS
NAME
COAL, BITUMINOUS
NATURAL GAS
BULK MATERIALS

\begin{tabular}{l}
\multicolumn{1}{c}{ NAME } \\
AMMONIA \\
ELECTRICITY (KWH) \\
LIQUIDD FUELS \\
, PROPYLENE.
\end{tabular}

MMOUNT (MT)

1.3620

.1290

AMOUNT (MT) .5000

1188.0000

1.4520

1.2370

BULK MATERTAL : POLYCARBUNATE RESIN

RAW MATERIALS

NAME

COAL, BITUMINOUS

NATURAL GAS

AMOUNT (MT)

.0330

.0410

BULK MATERIALS

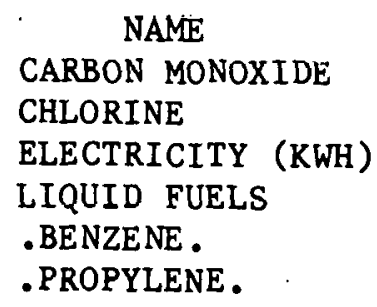

AMOUNT (MT)

.2660

.6670

300.0000

.0220

1.9590

1.0520 
TABLE A-4. BULK MATERIAL PRODUCTION PROCESSES (CONTINUED)

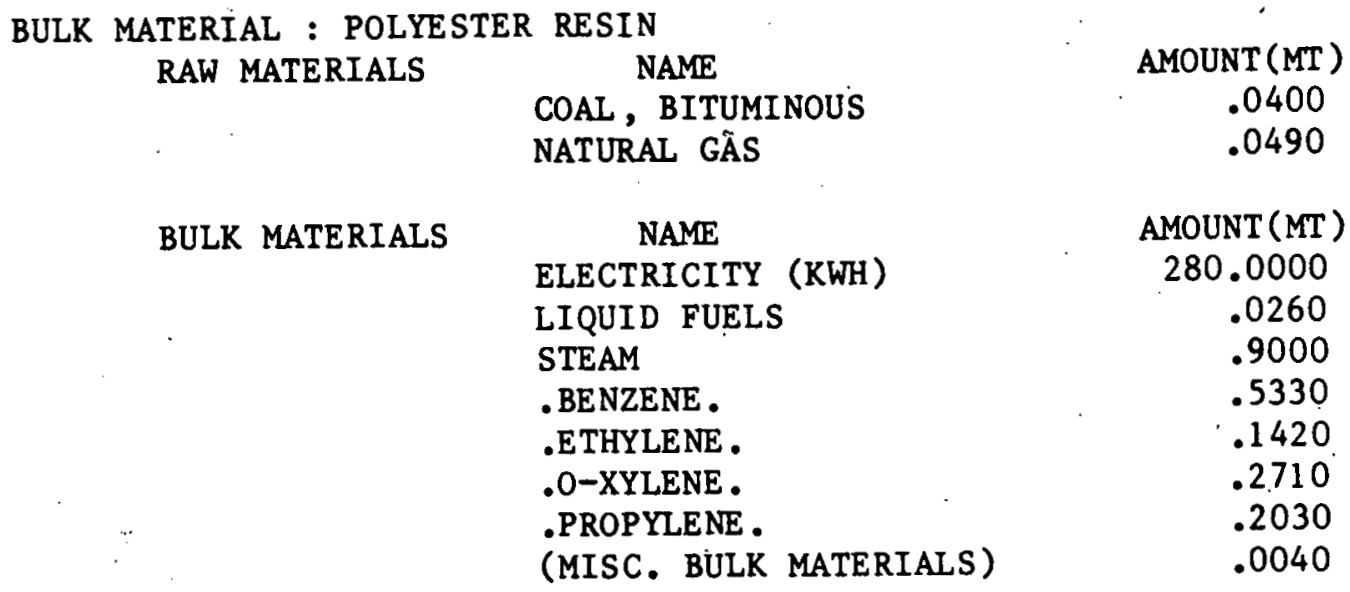

BULK MATERIAL : POLYETHYLENE (LDPE+HDPE)

RAW MATERIALS

NAME

COAL, BITUMINOUS

NATURAL GAS

BULK MATERIALS

NAME
ELECTRICITY (KWH)
LIQUID FUELS
.ETHYLENE.

BULK MATERIAL : POLYPROPYLENE

RAW MATERIALS

NAME

COAL, BITUMINOUS

NATURAL GAS

BULK MATERIALS

NAME
ELECTRICITY (KWH)
LIQUID FUELS
.PROPYLENE.

$$
\begin{array}{r}
\text { AMOUNT (MT) } \\
.0840 \\
.1040 \\
\text { AMOUNT (MT) } \\
1145.0000 \\
.0540 \\
1.0940
\end{array}
$$

AMOUNT(MT)
.0340
.0420

AMOUNT(MT)

662.0000

.0220

1.0530

BULK MATERIAL : POLYSULFONE

BULK MATERIALS

NAME

AMOUNT (MT)

1.0610

CHLORINE

.4910

SULFURIC ACID

1.6360

-BENZENE.

.2820 
TABLE A-4. BULK MATERIAL PRODUCTION PROCESSES (CONTINUED)

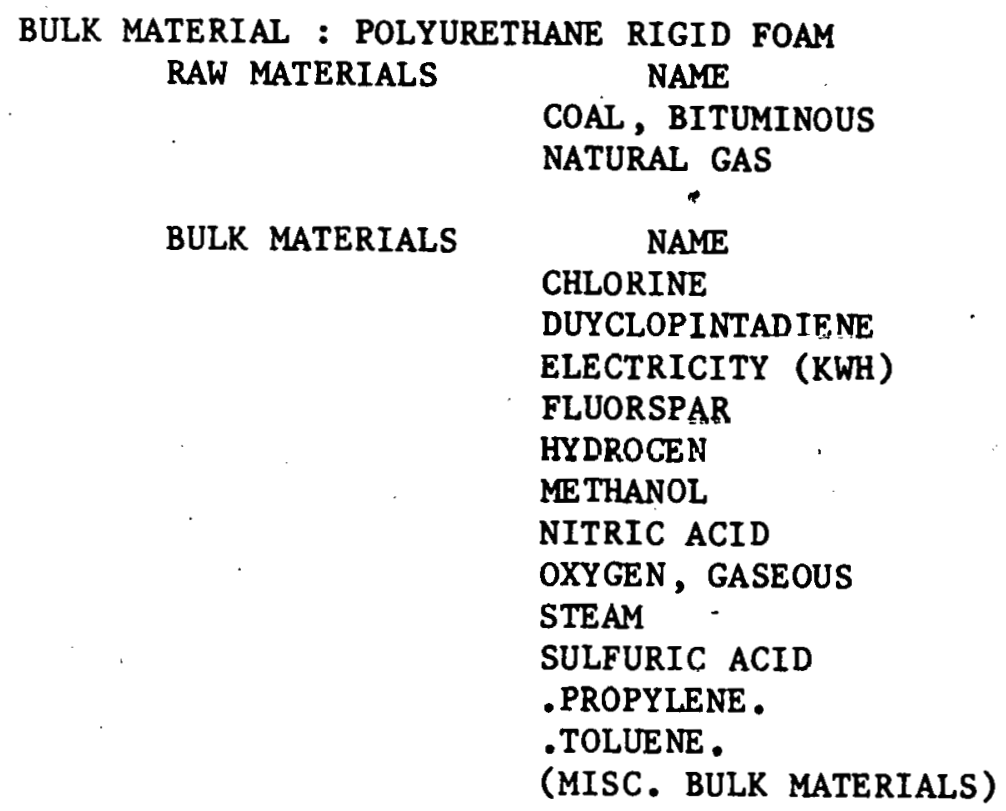

NAME

CHLORINE

DUYCLOPINTADIE NE

ELECTRICITY (KWH)

FLUORSPAR

HYDROCEN

ME THANOL

NITRIC ACID

OXYGEN, GASEOUS

STEAM

SULFURIC ACID

-PROPYLENE.

-TOLUENE.

(MISC. BULK MATERIALS)

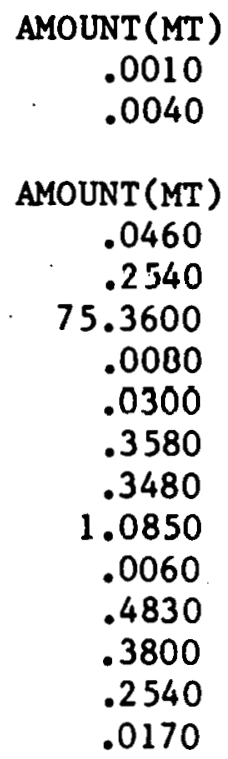

BULK MATERIAL : POLYVINYL FLUORIDE

RAW MATERIALS NAME

COAL , BITUMINOIIS

AMOUNT (MT)

.2130

BULK MATERIALS NAME

ACETYLENE

ELECTRICITY (KWH)

FLUORSPAR

STEAM

SULFURIC ACID

$$
\begin{array}{r}
\text { AMOUNT(MT) } \\
.6040 \\
164.0000 \\
1.0440 \\
.8120 \\
1.3230
\end{array}
$$

BULK MATERIAL : PORCELAIN

\begin{tabular}{ll} 
RAH MATERIALS & \multicolumn{1}{c}{ NAME } \\
& CLAYS \\
& FELDSPAR \\
& NATURAI GAS \\
BULK MATERIALS & \multicolumn{1}{c}{ NAME } \\
& ELECTRICITY (KWH)
\end{tabular}

AMOUNT (MT) .6950

.3580

1.0500

AMOUNT(MT)

25.0000

BULK MATERIAL : PROPYLENE. GLYCOL

BULK MATERIALS

$\quad$ NAME
CHLORINE
LIME
.PROPYLENE.

AMOUNT (MT)

1.2130

.8320

.7170 
TABLE A-4. BULK MATERIAL PRODUCTION PROCESSES

(CONTINUED)

BUILK MATERIAL : PVC PLASTIC

RAW MATERIALS
NAME
COAL, BITUMINOUS
NATURAL GAS

BULK MATERIALS

$\quad$ NAME
CHLORINE
ELECTRICITY (KWH)
LIQUID FUELS
.ETHYLENE.

BULK MATERIAL : RUBBER, SBR

RAW MATERIALS

COAL, BITUMINOUS

NATURAL GAS

BULK MATERIALS

NAME
CARBON BLACK
ELECTRICITY (KWH)
-BENZENE.
-BUTADIENE.
.ETHYLENE.
(MISC. BULK MATERIALS)

BULK MATERIAL : SILANE

BULK MATERIALS
AMOUNT(MT)

.0540

.0670

AMOUNT(MT)
1.3900
1830.0000
.0350
.5470

AMOUNT (MT)

.0380

.1040

AMOUNT (MT)

.3400

183.6000

.1400

.3780

.0520

.1370

AMOUNT (MT)

1.2100

7.2500

BULK MATERIAL : SILICA FIBER

BULK MATERIALS

NAME

AMOUNT (MT)

SAND \& GRAVEL

3.0000

BULK MATERIAL : SILICA VITREOUS, $99.99 \%$

RAW MATERIALS

NAME

AMOUNT (MT)

QUARTZ

1.0000

BULK MATERIALS

NAME

HYDROCHLORIC ACID

AMOUNT(MT)

.0100 


$$
\text { A-36 }
$$

TABLE A-4. BULK MATERIAL PRODUCTION PROCESSES

(CONTINUED)

BULK MATERIAL : SILICON MONOXIDE

RAW MATERIALS NAME

$$
\text { QUARTZ }
$$

BULK MATERIALS

$$
\begin{gathered}
\text { NAME } \\
\text { SILICON (SEG) }
\end{gathered}
$$

BUILK MATERIAL : SILICON TETRACHLORLDE
AMOUNT (MT) .7000

AMOUNT (MT)

.3200

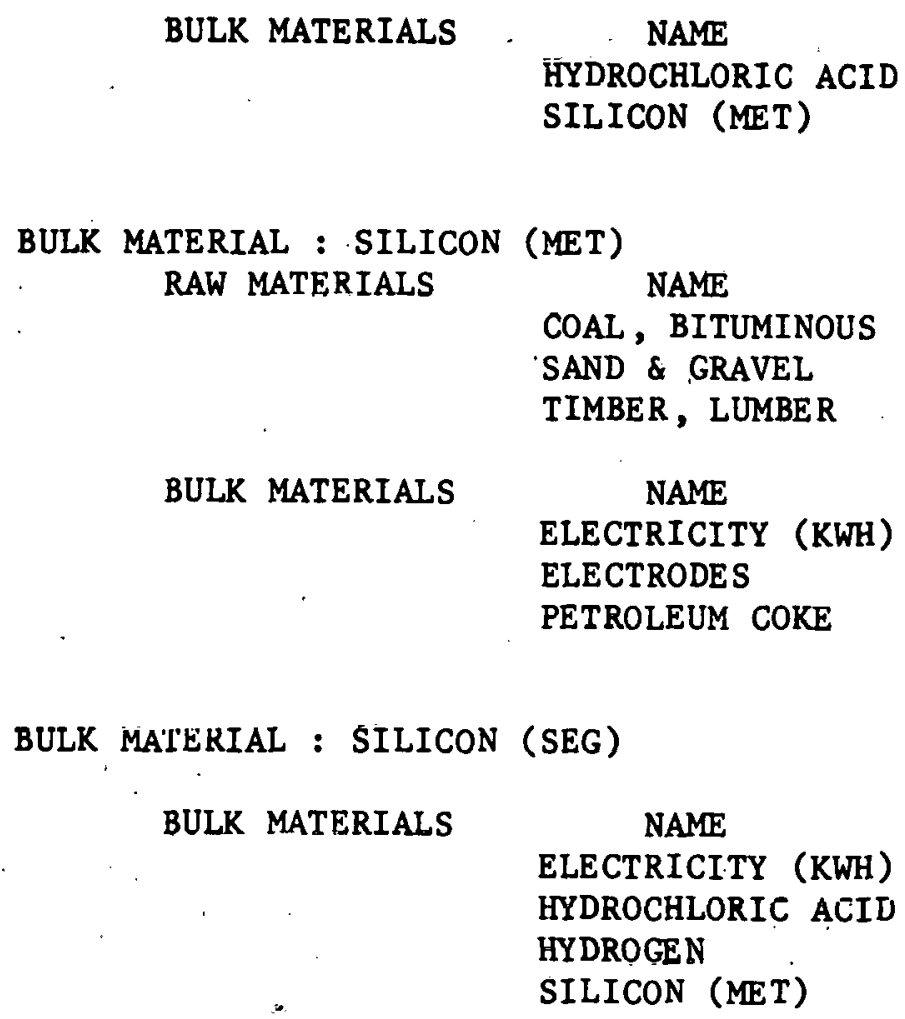

BULK MATERIALS - NAME

BULK MATERIAL : SILICON (MET)

RAW MATERIALS

NAME
COAL, BITUMINOUS
SAND \& GRAVEL
TIMBER, LUMBER

BULK MATERIALS
NAME
ELECTRICITY (KWH)
ELECTRODES
PETROLEUM COKE

BULK MAIERIAL : SILICON (SEG)

BULK MATERIALS

NAME
ELECTRICITY (KWH)
HYDROCHLORIC ACID
HYDROGEN
SILICON (MET)

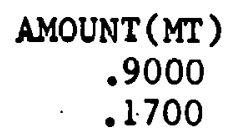

AMOUNT (MT)

1.2350

3.6570

1.0250

AMOUNT (MT)

13200.0000

.1825

.4250

AMOUNT(MT)

2304000.0000

17.6000

.1930

4.4900

BULK MATERIAL : SILICONES

RAW MATERIALS

NAME
NATURAL GAS
NAME
CHLORINE
SILICON (MFT)

AMOINT (MT)

.6730

AMOUNT (MT)

2.9650

.5850 


$$
\text { A-37 }
$$

TABLE A-4. BULK MATERIAL PRODUCTION PROCESSES (CONTINUED)

BULK MATERIAL : SILVER RAW MATERIALS

$$
\begin{aligned}
& \multicolumn{1}{c}{\text { NAME }} \\
& \text { NATURAL GAS } \\
& \text { SILVER ORE }
\end{aligned}
$$

BULK MATERIALS

\begin{tabular}{l}
\multicolumn{1}{c}{ NAME } \\
ELECTRICITY (KWH) \\
LIME \\
LIQUID FUELS \\
OXYGEN, LIQUID \\
SODIUM CARBONATE \\
SODIUM CYANIDE \\
STEAM \\
STEEL \& IRON \\
SULFURIC ACID \\
ZINC \\
(MISC. BULK MATERIALS)
\end{tabular}

$$
\begin{array}{r}
\text { AMOUNT(MT) } \\
8.2740 \\
1430.0000 \\
\text { AMOUNT(MT) } \\
164350.0000 \\
10.8300 \\
8.9000 \\
.0140 \\
2.0700 \\
.4000 \\
7.0200 \\
1.5400 \\
4.8600 \\
.2200 \\
2.3300
\end{array}
$$

BULK MATERIAL : SODIUM BOROHYDRIDE

$$
\text { BULK MATERIALS }
$$

NAME ME THYL BORATE SODIUM HYDRIDE,

BULK MATERIAL : SODIUM CARBONATE RAW MATERIALS

NAME COAL, BITUMINOUS LIMESTONE SALT

BULK MATERIALS

NAME
AMMONIA
COKE
ELECTRICITY (KWH)
(MISC. BULK MATERIALS)

$$
\begin{gathered}
\text { AMOUNT (MT) } \\
3.1000 \\
2.8000
\end{gathered}
$$

$$
\begin{array}{r}
\text { AMOUNT(MT) } \\
.4500 \\
1.2200 \\
1.5650 \\
\cdot \\
\text { AMOUNT(MT) } \\
.0025 \\
.1000 \\
47.0000 \\
.0005
\end{array}
$$

AMOUNT (MT)

1.4500

1.0500

NATURAL GAS

AMOUNT (MT)

551.0000

.4500

1.0000

.5880 
TABLE A-4. BULK MATERIAL PRODUCTION PROCESSES

(CONTINUED)

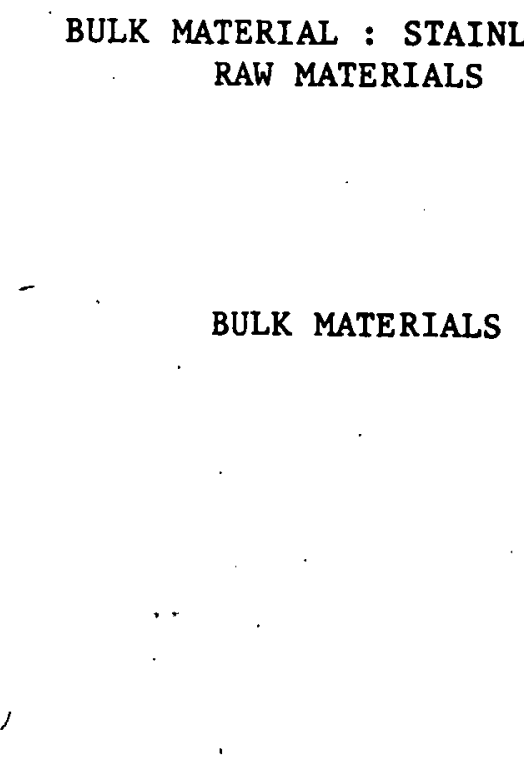

BULK MATERIAL : STEAM RAW MATERIALS
NAME

CHROMITE

LIMESTONE

NATURAL GAS

NICKEL ORE

$\quad$ NAME
ALUMINUM
ELECTRICITY (KWH)
ELECTRODES
FERROMANGANESE
FERROSILICON
FERROUS SCRAP, PURCHASED
FLUORSPAR
LIME
OXYGEN, GASEOUS
(MISC. BULK MATERIALS)

COAL, . BITUMINOUS

AMOUNT (MT)

.1120

$$
\begin{gathered}
\text { AMOUNT(MT) } \\
.7680 \\
.0100 \\
.0030 \\
8.4000 \\
\\
\text { AMOINT (MT) } \\
.0010 \\
606.0000 \\
.0060 \\
.0110 \\
.0010 \\
.6620 \\
.0050 \\
.0300 \\
.0110 \\
.0130
\end{gathered}
$$

BULK MATERIAL : STEEL \& IRON RAW MATERIAISS

$\quad$ NAME
IRON ORE.
LIMESTONE
NATURAL GAS

BULK MATERIALS

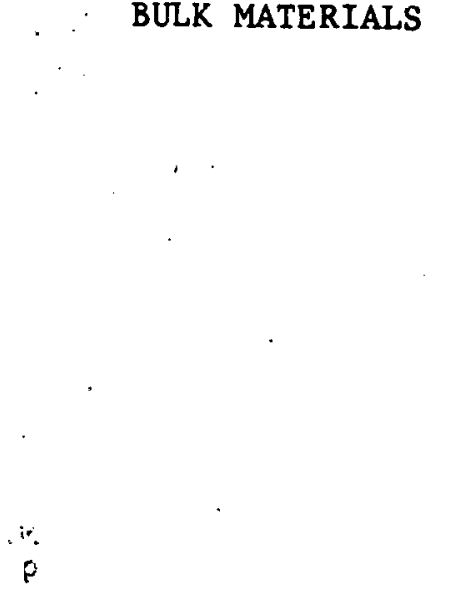

AMOUNT (MT)

1.6200

.1610

.0150

AMOUNT (MT)

.0010

.3820

159.0000

.0010

.0110

.0010

.2410

.0070

.0550

.0190

.0710

.3840

.0490 


$$
\text { A-39. }
$$

TABLE A-4. BULK MATERIAL PRODUCTION PROCESSES (CONT INUED)

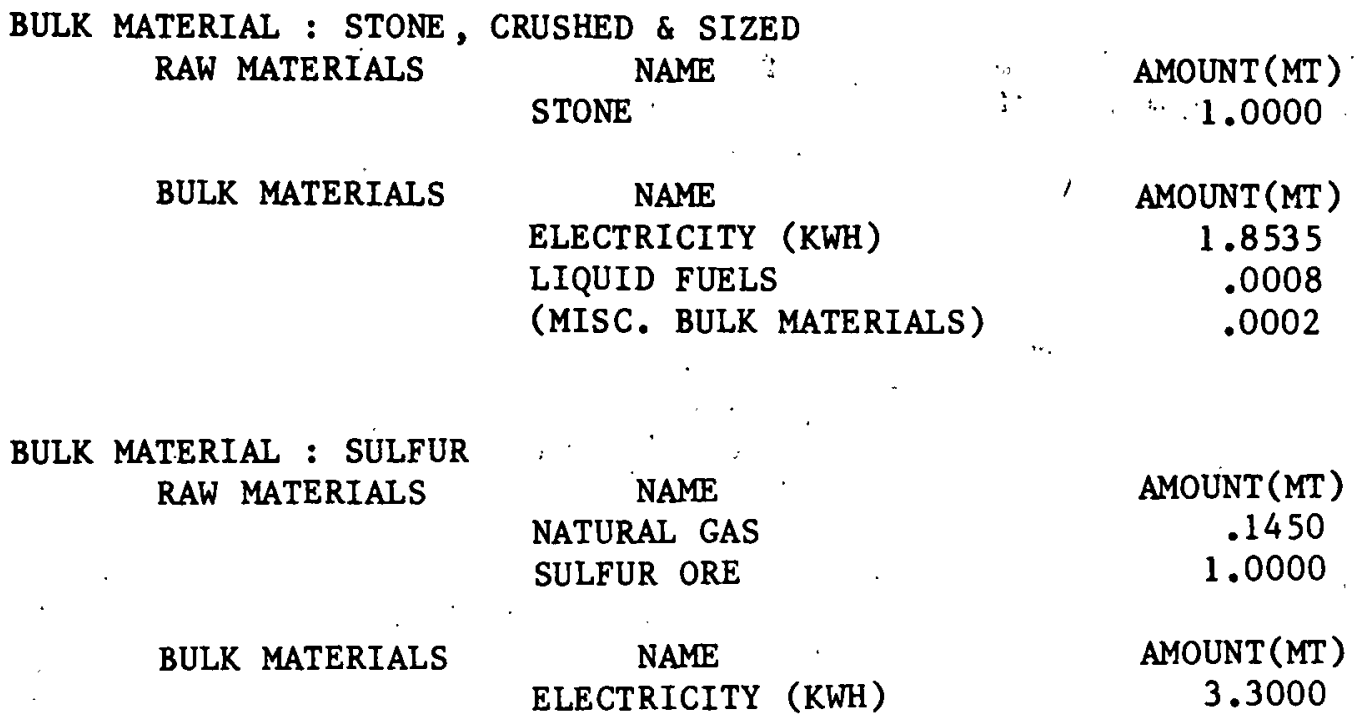

NAME NATURAL GAS SULFUR ORE

BULK MATERIALS

NAME ELECTRICITY (KWH)

AMOUNT (MT)

.1450

1.0000

AMOUNT(MT)

3.3000

BULK MATERIAL : SULFURIC ACID

BULK MATERIALS

NAME

ELECTRICITY（KWH） SULFUR

AMOUNT(MT)

9.0000 .3370

BULK MATERIAL : TANTALUM RAW'MATERIALS

NAME

NATURAL GAS

TANTALUM ORE

800.0000

BULK MATERIALS

NAME

ELECTRICITY (KWH)

HYDROCHLORIC ACID

HYDROFLUORIC ACID

METHANOL

STEAM

(MISC. BULK MATERIALS)

AMOUNT (MT)

636.0000

1.3400

2.0000

.9000

2.1600

7.7360

BULK MATERIAL : TEFLON

RAW MATERIALS

NAME

NATURAL GAS

AMOUNT (MT) .6380

BULK MATERIALS 


$$
\text { A-40 }
$$

TABLE A-4. BULK MATERIAL PRODUCTION PROCESSES

(CONTINUED)

BULK MATERIAL : TIN

RAW MATERIALS

NAME
LIME STONE
TIN ORE

BULK MATERIALS

NAME
COKE
ELECTRICITY (KWH)
LIQUID FUELS
(MISC. BULK MATERIALS)

BULK MATERIAL : TITANIUM RAW MATERIALS

\begin{tabular}{l}
\multicolumn{1}{c}{ NAME } \\
LIMESTONE \\
NATURAL GAS \\
RUT ILE (CONC.) \\
\multicolumn{1}{c}{ NAME } \\
ARGON \\
CHLORINE \\
ELECTRICITY (KWH) \\
HELIUM \\
MAGNESIUM \\
NITRIC ACID \\
PETROLEUM COKE
\end{tabular}

BULK MATERIAL : TRICHLOROSILANE

BULK MATERIALS

NAME
HYDROCHLORIC ACID
SILICON (MET)

BULK MATERIAL : TRIMETHLY AL., COMM.

BULK MATERIALS

$$
\begin{aligned}
& \quad \text { NAME } \\
& \text { DIMETHYL ALUM. CHLORIDE } \\
& \text { SODIUM }
\end{aligned}
$$

BULK MATERIAL : TRIMETHYL AL, , 99.9999\%

BULK MATERIALS

NAME

TRIMETHLY AL ., COMM.

$$
\begin{array}{r}
\text { AMOUNT(MT) } \\
.0470 \\
100.0000 \\
\\
\text { AMOUNT(MT) } \\
.2850 \\
16733.0000 \\
.1210 \\
.1440
\end{array}
$$

$$
\begin{array}{r}
\text { AMOUNT (MT) } \\
.0061 \\
.3502 \\
2.1740 \\
\text { AMOUNT(MT) } \\
.0271 \\
1.0000 \\
25855.0000 \\
.0029 \\
.3100 \\
.0171 \\
.6000
\end{array}
$$

AMOUNT(MT)

4.8000

1.0600
AMOUNT(MT)

2.5000

.6200

AMOUNT (MT)

1.0800 
TABLE A-4. BULK MATERIAL PRODUCTION PROCESSES (CONTINUED)

BULK MATERIAL : TRIMETHYL GA., 99.9995\%

BULK MATERIALS

NAME

GALLIUM TRICHLORIDE

AMOUNT (MT)

TRIMETHLY AL., COMM.

2.4600

2.0000

BULK MATERIAL : TRIMETHYL INDIUM, 99.998\%

BULK MATERIALS

NAME

INDIUM TRICHLORIDE

AMOUNT(MT)

TRIMETHLY AL., COMM.

2.0700

.6700

BULK MATERIAL : TUNGSTEN

RAW MATERIALS

NAME

NATURAL GAS

SODA ASH (NAT.)

TUNGSTEN ORE

BULK MATERIALS

NAME

AMMONIA

CAUSTIC SODA

ELECTRICITY (KWH)

HYDROCHLORIC ACID

HYDROGEN

LIME

LIQUID FUELS

SODIUM CYANIDE

STEEL \& IRON

(MISC. BULK MATERIALS)

AMOUNT (MT)

1.4760

.2415

167.0000

AMOUNT (MT)

.4400

1.2350

4102.0000

5.0400

.0904

.1095

4.6080

.0550

.3065

.1870

BULK MATERIAL : ZINC

RAW MATERIALS

NAME

NATURAL GAS

ZINC ORE

AMOUNT(MT)

.1350

22.2000

BULK MATERIALS

NAME

ELECTRICITY (KWH)

LIQUID FUELS

STEEL \& IRON

SULFURIC ACID

(MISC. BULK MATERIALS)

AMOUNT(MT)

5413.0000

.0560

.0250

.0840

.0810 
TABLE A-4. BULK MATERIAL PRODUCTION PROCESSES (CONTINUED)

BULK MATERIAL : ZINC ARSENIDE

\begin{tabular}{llc} 
BULK MATERIALS & \multicolumn{1}{c}{ NAME } & AMOUNT(MT) \\
& ARSENIC \\
& ZINC & .4400 \\
& & .5800
\end{tabular}

BULK MATERIAL : ZINC FLUOROBORATE

\begin{tabular}{ll} 
BULK MATERIALS & \multicolumn{1}{c}{ NAME } \\
& BORAX \\
& HYDROFLUORIC ACID \\
& SULFURIC ACID \\
& ZINC,
\end{tabular}
AMOUNT(MT)
.8000
.6700
.2100
.2800

BULK MATERIAL : . BENZENE. RAW MATERIALS

NAME

NATURAL, GAS

AMOUNT(MT) .0350

PETROLEUM

174.2200

BULK MATERIALS

NAME

ELECTRIGITY（KWH）

AMOUNT (MT)

15.6790

BULK MATERIAL : .BUTADIENE. RAW MATERIALS

NAME

NATURAL GAS

AMUUN'T (MT)

.2950

PETROLEUM

73.7460

BULK MATERIALS

NAME
ELECTRICITY (KWH)

AMOINT (MT)

15.4870

BULK MATERIAL : .ETHYLENE. RAW MATERIALS

NAME

NATURAL GAS

AMOUNT(MT)

.3100

PETROLEUM

10.0120

BULK MATERIALS

NAME

ELECTRICITY（KWH）

AMOUNT (MT)

15.4190 


$$
\text { A-43 }
$$

TABLE A-4. BULK MATERIAL PRODUCTION PROCESSES

(CONTINUED)

BULK MATERIAL : .0-XYLENE. RAW MATERIALS

BULK MATERIALS

NAME

NATURAL GAS

PETROLEUM

NAME
ELECTRICITY (KWH)

BULK MATERIAL : .PROPYLENE.

RAW MATERIALS

$$
\begin{aligned}
& \multicolumn{2}{c}{\text { NAME }} \\
& \text { NATURAL GAS } \\
& \text { PETROLEUM }
\end{aligned}
$$

BULK MATERIALS
AMOUNT (MT)

.5850

146.3300

AMOUNT (MT)

30.7300

AMOUNT (MT)

.3030

20.2100

AMOUNT (MT)

15.3600 


\section{APPENDIX A REFERENCES}

(See also Primary Report References)

(1) Litchfield, J.W., Watts, R. L., et al., "A Methodolgy for Identifying Materials Constraints to Implementation of Solar Energy Technologies", Battelle Pacific Northwest Laboratorles, Richland, WA, July, 1978.

(2) Watts, R: L., Gurwell, W. E., et al, "Some Potential Material Supply Constraints in the Deployment of Photovoltaic Solar Electric Systems", Batrelle Pacific Northwest Laboratories, Richland, Washington, September, 1978.

(3) Watts, R. L., Gurwell, W. E., et al, "Some Potential Material Supply Constraints in Solar Systems for Heating and Cooling of Buildings and Process Heat", Battelle Pacific Northwest Laboratories, Richland, Washington, September, 1978. 
DISCUSSION OF RESERVES AND RESOURCES

In discussing 1ssues relative to reserves and resources it is important to understand the distinction made between these two terms. The relationship between reserves and resources is shown in the Mineral Resource Classification System developed jolntly by the U.S. Geological Survey and the U.S. Bureau of Mines (see Figure B-1).

This diagram illustrates changing qualities of resources in terms of increasing geologic assurance and increasing economic feasibility. In this two-dimensional diagram, reserves are represented by the shaded area. In this context, reserves are defined as that portion of the resource that is located in identifled deposits and can be economically extracted given current technology and mineral prices. This diagram is a static representation of a dynamic system where the quantity of reserves is continually changing due to changes in extraction and mining technology, fluctuations in market prices, and also the extent of exploration.

U.S. government estimates of available resources and reserves historically have been very conservative. For example, consider the case of bauxite (aluminum ore). Selected U.S. Bureau of Mines estimates over the 1945-1977 time span are listed below and shown graphically in Figure $B-2$ :

$$
\begin{array}{rr}
1945 & -1 \times 10^{9} \text { tons } \\
1955-3 \times 10^{9} \\
1965 & 6 \times 10^{9} \\
1975 & 17 \times 10^{9} \\
1977 & 24 \times 10^{9}
\end{array}
$$

Over a 32 year time span, this represents a $2400 \%$ increase in reserve estimates.

Similarly bauxite resource estimates in 1963 and 1975 were:

$$
\begin{array}{ll}
1963 & 14.5 \times 10^{9} \text { tons } \\
1975 & 40 \times 10^{9}
\end{array}
$$




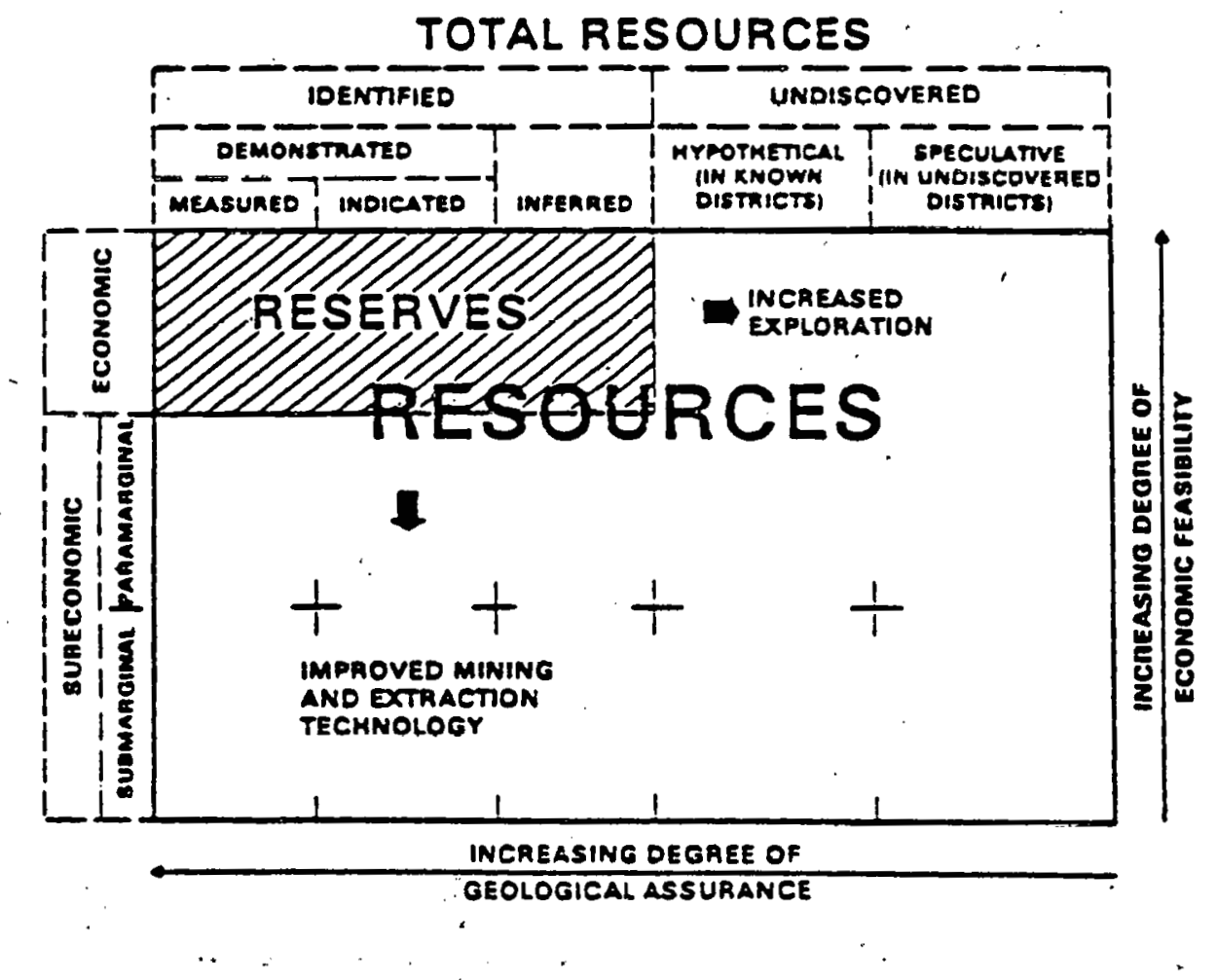

Figure B-1. CLASSIF ICATION OF MINERAL RESOURCES*

*Commodity Data Summaries 1977. Burean of Mines, U.S. Department of Interior, Washington, D.C., 1977 


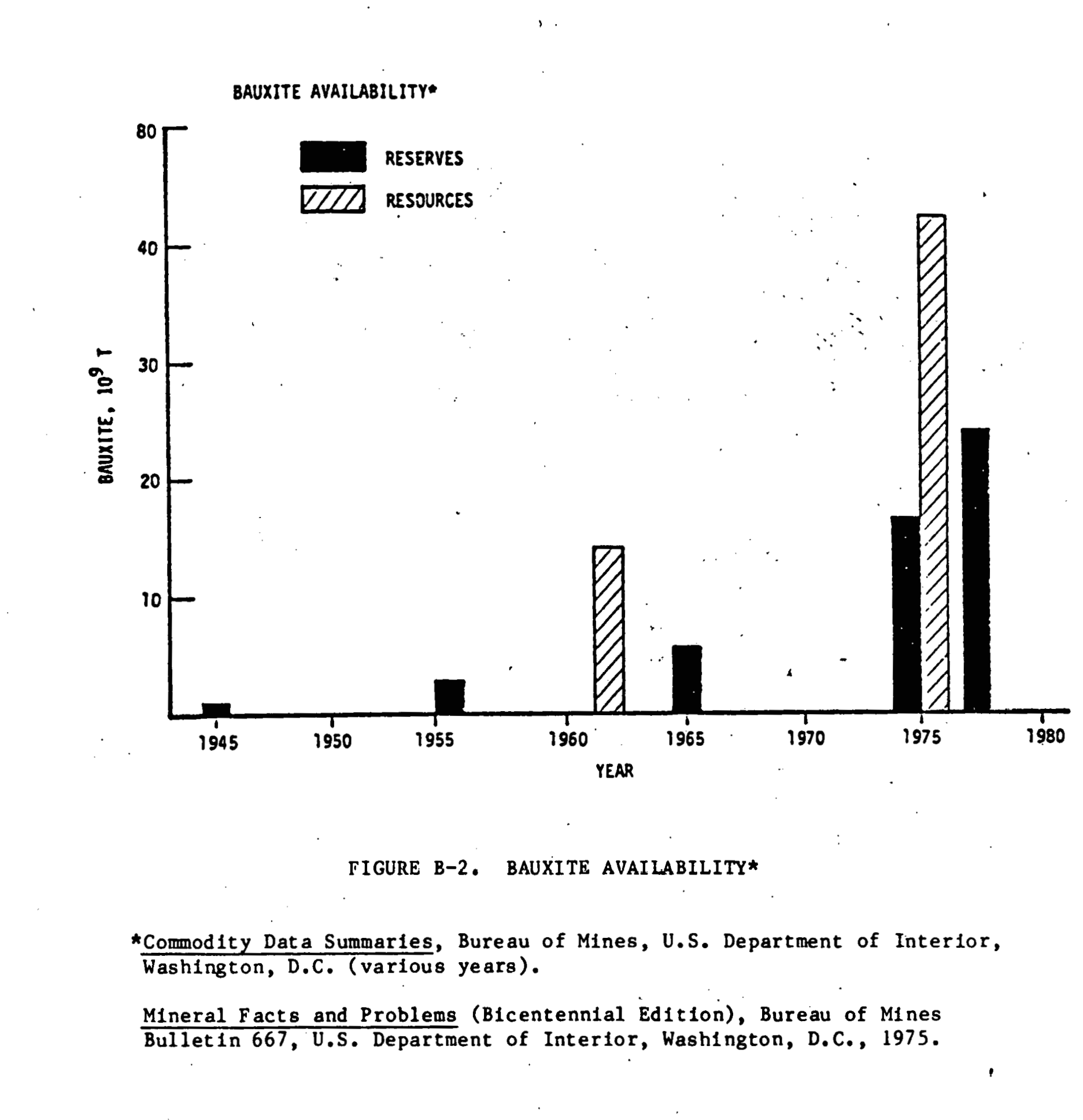


This represents over $275 \%$ increase in resource estimates over a 12-year span (see also Figure B-2). For comparison of availability with consumption, the 1975 consumption of bauxite was only $0.3 \times 10^{9} \mathrm{MT}$ (U.S. Bureau of Mines estimate), a very small fraction of reserves and resources for what is a recyclable commodity.

These increases are due to major new discoveries, technological. advances in recovery processes permitting inclusion of lower grade bauxite ores and upward movement in prices for aluminum, e.g., $\$ 0.22 / 1 b$ In current dollars in 1954 to $\$ 0.40 / 1 \mathrm{~b}$ in 1975 to $\$ 0.60+/ 1 \mathrm{~b}$ today. In conștant 1973 prices, the increase is more l1ke $10 \%$ to $15 \%$ over the 25-year time span.

Even estimates of petroleum reserves and resources are being. vastly increased under todays new ground rules on prices. 1978 study by the International Institute for Applied Systems Analysis in Austria estimates 2.1 trillion barrels of world oil resources recoverable at $\$ 20 /$ barrel in 1976 dollars*--a 95 year supply at present world rates of production.

Assessment of the criticality of materials from a reserves and resources standpoint must allow for the conservative nature of avallability estimates. For this reason, materials assessment threshold values for these parameters have been set at high levels: 400 percent for U.S. reserves, 300 percent for U.S. resources, and 200 percent for world resources. In most cases even these values are conservative. 